\title{
Thermal Design and Analysis of the HTGR Fuel Element Vertical Carbonizing and Annealing Furnace
}

\author{
G. H. Llewellyn
}




Printed in the United States of Arnerica. Available from
National Technical Information Service
U.S. Oefartmerit of Commerce
5285 Port Royal Road. Springfield, Virginia 22161
Price: Printed Copy $\$ 5.00$. Microfiche $\$ 3.00$

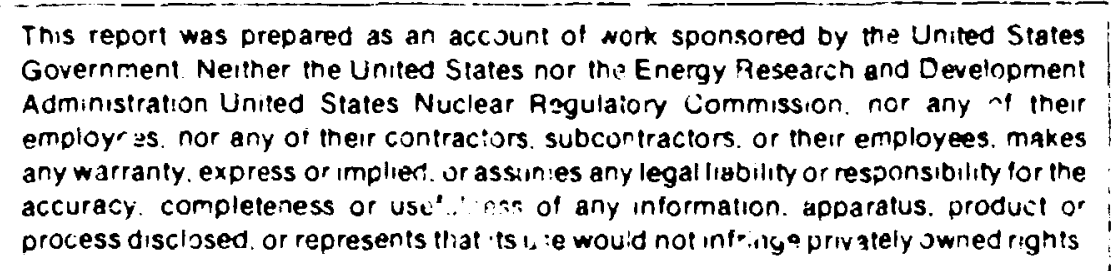


Contract io. W-7405-eng-26

ORNL Engineering

THERMAL DESIGN AND ANALYSIS OF THE : GR FUEL ELEMENT VERTICAL CARBONIZING AND ANNEALIAG FLRNACL

G. H. Llewe 1 lyn

Date Published: June 1977

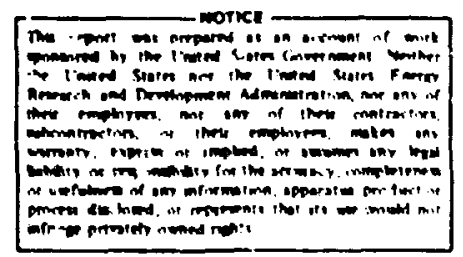

OAK RIDGE NATIONAL LABORATORY

Oak Ridge, Tennessee 37830

cpersted by

UNION CARB IDE CORPORATION

Nuclear Division

for the

ENERGY RESEARCH AND DEVELOPMENT ADMINISTRATION 
CONTENTS

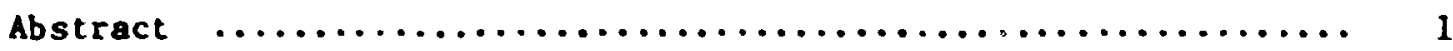

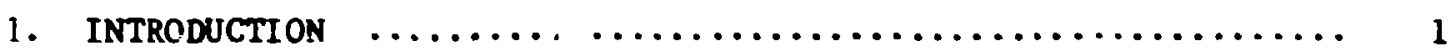

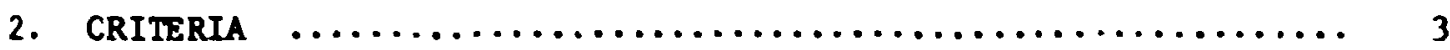

3. CARBONIZING AND ANNEAIING FURNACE $\ldots \ldots \ldots \ldots \ldots \ldots \ldots \ldots \ldots \ldots$

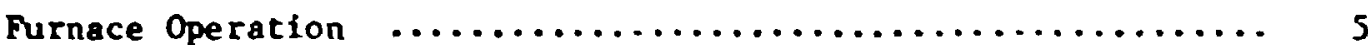

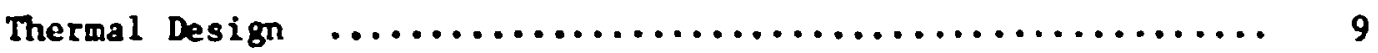

4. ENERGY TRANSPORT SIMULATION TN THE MOVING COLUMN $\ldots \ldots \ldots \ldots \ldots .14$

Determination of Volumetric lieat Generation Rate $\ldots \ldots \ldots \ldots . . .15$

Heat Balance in Graphite Colunr. $\ldots \ldots \ldots \ldots \ldots \ldots \ldots \ldots \ldots . \ldots \ldots$

5. HEAT TRANSFER MUDELS AND BOUNDARY CON_ITIONS $\ldots \ldots \ldots \ldots \ldots \ldots .21$

6. Material PROPERTtes USEd IN THERMal analysis $\ldots \ldots \ldots \ldots \ldots \ldots .29$

7. RESULTS OF THERMAL ANALYSIS, CONCLUSIONS, AND

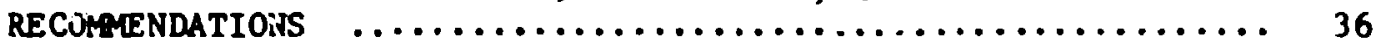

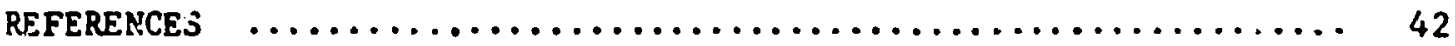

Appendix A: MASS-FLON SIMULATION DATA FOR FUEL ELEMENTS FABRICATED FROM H-327 GRAPHITE $\ldots \ldots \ldots \ldots \ldots \ldots \ldots \ldots, 45$

Append IX B: MASS-FLOW SIMULATI IN DATA FOR FUEL ELEMENTS FABRICAICD FROM H-451 GRAPHITE $\ldots \ldots \ldots \ldots \ldots \ldots \ldots .69$

Appond1X C: THERMAL CONDUC'TIVITY DATA AS A FUNCTION OF TEMPERATURE FOR FUEL. ELEMENTS PABRICAIED FROM TYPE H-.127 AND TYPE H-451 GRAPHI TE 
Figure Number

1

2

3

i

5

6

7

8

9

10

$1 \mathrm{i}$

14

15
Title

Typical Fort St. Vrain Active Core Elcment

Proposed tiTGR Fiel Eleient Vertical Carbonizing and Annealing Fursace

Operational Diazram of Furnuce Design

Desired Temperature of Outer Surface of Fuel Elements as a Function of Axial Location in Furnace

Iaternal Volumetric Heat Generation Rate Required for Simulation of Mass Flow af Fuel Elements Fabricated From H-327 Graphite as a Function of Their Axial Position in the Furnace for the Top-Loaded Configuration

Internal Vclumetric Heat Generation Rate Required for Simulation of Mass Flow of Fuel Elements Fabricated From H-32? Graphite as a Function of Their Axial Position in the Furnacs for the Bottom-Loaded Configuration

Computer Model of Upper Portion of Furnace for TopLoaded Configuration

Computer Kodel of Middle Portion of Furnace fnt Topanu Bottom-Loaded Configurations

Computer Model of Lower Portion of Furnece for TopLoaded Configuration

Computer Model of Upper Portion of Furnace for BottomLoaded Configuration

Computer Model of Lower Portion of Furnace for BottomLoaded Configuration

Results of Computer Analysis of Furnace Design Comparej With Desired Temparature Profile for Top-Loaded Configuration

Results of Computer Analy is of Furnace Des:gn Compared Wich Desired Temperature Profjle for BottomLoaded Configuration

Results of Computer Analyses Obtained By Varying Insulation in Upper Portion of Furnace Conipared with Desired Temperature Profile for Top-Loaded Configuration

Results of Computer Analyse Obtained By Varying Insulation in Upper Portion of Furnace Compared With Desired Temperature Profile for Bottom-Loaded Configuratior
8

I0

rage

Number

4

6

8

19

20

22

23

24

25

26

38

39

40

41 
A.1 Centigrade Temperature Criteria for the Surface of Fuel Elements Fabricated From H-327 Graphite as a Number Function of Their Axial Position in the Furnace for the Top-Loaded Configuration

A.2 Fahrenineit Temperature Criteria for the Surface of Fuel Elements Fabricated From H-327 Graphite us a Function of Their Axial Position in the Furnace for the Top-Loaded Configuration

A.3 Axial Heat Transfer From Mass Flow of Fuel Elements Fabricated From H-327 Graphite as a Function of Their Axial Position in the Furnace for the rop-Loaded Configuration

A.4 Axial Heat Transfer From Axial Conduction in Fuel Elements Fabricated From H-327 Graphite as a Function of Their Axial Position in the Furnace for the Top-Loaded Configuracion

A.5 Axial Heat Transfer From Mass Flow of Argon Gas as a Function of Axial Position in the Furnace for the Top-Loaded Configuration

A.6 Total Radial Power Input, Excluding External Losses, Required to Process Fuel Elements Fabricated From H-327 Graphite as a Function of Their Axial Position in the Furnace for the Top-Loaded Configuration

A.7 Composite Axial Power Distribution for Processing Fue 1 Elements Fabricated From i-327 Graphite as a Function of Their Axial Position in the Firnace for the TopLoaded Configuration

A.8 Centrigrade Temperature Criteria for the Surface of Fue i Elements Fabricated From $\mathrm{h}-327$ Graphite as a Function of Their Axial position in the Furnace for the Bottom-Loaded Configuration

A.9 Fahrenheit Temperature Criteria for the Surface of Fue 1 Elements Fabricated From H-32? Graphite as a Function of Their Axial Position in the Furnace for the Bottom- $L$ aded Configuration

n.10 Axial Heat Transfer From Mass Flow of Fuel Elements Fabricated From H-327 Graphite as a Function of Their Axial Position in the Furnace for the Bottom-Loaded Configuration

A.11 Axial Heat Transfer From Axial Conduction In Fuel Elements Fabricated From H-327 Grephite as a Function of Their Axial Position in the Furnace for the BottomLoaled Configuration 
Axial Heat Transfer From Mass Flow of Argon Gas as a Function of Axial Position in the Furnace for the Eottom-Loaded Configuration

A. 13

Total Padial Power Input. Excluding External Losses, Required to Process Fuel Elements Fabricated From H-327 Graphite as a Function of Their Axial Position in the Furnace for the Bottom-Loaded Configuration

A. 14 Composite Axial Power Distribution for Processing Fuel Elements Fabricated From M-327 Graphite as a Function of Their Axial Position in the Furnace for the BottomLoaled Configuration

C.1 Axial and Radial Thermal Conductivities of Composite Fuel Elements Made With Unirradiated H-327 Graphite as 2 Function of Temperature

C.2 Axial and Radial Thermal Conductivities of Composite Fut 1 Elements Made With Unirradiated H-451 Graphite as a Function of Temperature 


\title{
THERMAL DESIGN AND ANALYSIS OF THE HTGR FUEL ELEMENT VERTICAL CARBONIZING AND ANNEALING FURNACE
}

\begin{abstract}
Computer analyses of the thermel design for the proposed HTGR fuel element vertical carbonizing and annealin. furnace were performed to verify its capability and to determine the required power input and distribution. Although the furnace is designed for continuous operation, steady-state temperature distributions were obtained by assuming internal heat generation in the fuel elements to simulate their mass movement. The furnace thermal design, the analysis methods, and the results are discussed herein.
\end{abstract}

\section{INTRODUCTION}

One step in the process under development at Oak Ridge National Laborazory (ORNL) for remote fabrication of fuel elements from recycled ${ }^{233} \mathrm{U}$ for use in high-temperature gas-cooled reactors (HTGR) operated on the thorium fuel cycle involves in-place zarbonization and annealing of pitch-bonded fuel rods in graphite fuel element blocks. Coated fuel particles are bonded into rods with pitch, these rods are loaded into holes in prisnatic graphite blocks, and the entire fuel element is heated to carbonize the pitch bonding material and then to anneal the carbon and produce stable fuel rods. To accomplish this step, the design for a vertical, remotely operable furnace was developed, and the thermal analysis of that furnace design is ciescribed in ihis report.

Thermal analyses were performed as part of the work involved in the development of the current furnace design. The steady-state thermal analysis of that design reported herein was performed to verify its capability to achieve the desired axial temperature distribution in the fuel Elements as a function of time and to determine the power input and disirfbution to the furnace heaters required for meintenance of the desired temperature proftle. As well as the power input to the heaters, 
maintenance of the desired temperature profile 18 dependent upon the mass flow rate of the material going through the furnace, the thermal properties of the materials involved, and the boundary conditions at the cooling surfaces.

The criteria for the carbonizing and annealing furnace are discussed briefly in Section 2 , and the furnace operation and thermal design are described in Section 3. The furnace design provided the basis for deve1opment of two-dimensional mathematical heat transfer models in the form of nodal layouts of the furnace. The HEATING4 computer program, which is a modification of the generalized heat conduction program HEATING3, ${ }^{1}$ was used to obtain steady-state temperature distributions in these models. The HEATING programs have been used at ORNL for several years and have been updated during this period with new solution techniques and new boundary condition subroutines to the extent that any of the main variables can be expressed as functions of the other variables. The feature of anisotropic conduction was added to the program capabilities for analysis of the furnace. This feature was necessary inasmuch as the fual elements, furnace liner, and some of the insulation have different axial and radial thermal conductivities.

The mass movement of fuel elements through the furnace was simulated to obtain heat input data for the HEATING4 program analysis of the furnace thermal design. This simulation is described in section 4. The heat transfer models used in the computer analysis are described and the furnace boundary conditions developed for the analysis are discussed in Section 5. The thermal conductivity data for the furnace materials of construction used in the steady-state analysis are given in Section 6 , and the results of the analysis are discussed in Section 7 . The conclusions drawn from the results of the analysis are also presented in Section 7 , as are recomendations relative to future analyses. 


\section{CRITERIA}

The refabricated HTGR fuel elements wich the carbonizing and annealing furnace was designed to accomodate are the type to be used in the active core of the Fort St. Vrain Reactor (FSVR). As illustrated in Fig. i, a typical FSVR fuel element is a hexagonal prism that is 14.17 in. across the flats and 31.22 in. long at room temperature. The prism or fuel block is to be fabricated from inirradiated needle-coke (type H-327) grapinite as manufactured by the Great Lakes Carbon Company. The block may possibly be fabricated from type $\mathbf{1 - 4 5 1}$ graphite at a later date. As indicated in Fig. 1, each HTGR fuel element will contain six holes for burnable poison, 108 coolant holes, and 210 fuel holes. The fie 1 holes will be loaded with "green" fuel rods comprised of a mixture of graphite-coated uranium-oxide and thorium-oxide particles bonded with pitch. These holes will then be sealed with graphite plugs cemented in place at the top. Each assenbled fuel element will have a maximum weight of approximately $300 \mathrm{lb}$.

The thermal criteria for the carborization and anneaiing of HTGR fuel rods placed in the graphite blocks specify a beginning minimum carbonization temperature of $300^{\circ} \mathrm{C}$ and a thermal rise not to exceed $10^{\circ} \mathrm{C}$ per minute up tu a temperature of $800^{\circ} \mathrm{C}$, resulting in a carbonization period of $5 C$ rinutes. Following carbonization, an annealing step is required to completely drive off any remaining volatile materials. During this step, the temperature of the graphite must be maintaired above $1750^{\circ} \mathrm{C}$ and below $1850 \mathrm{C}$ for a period of at least 15 minutes but not to exceed 90 minutes. Before discharge from the iurnace, each fuel element mist be cooled so that the temperature of eny graphite exposed to ambient air will be be low $200^{\circ} \mathrm{C}$. 


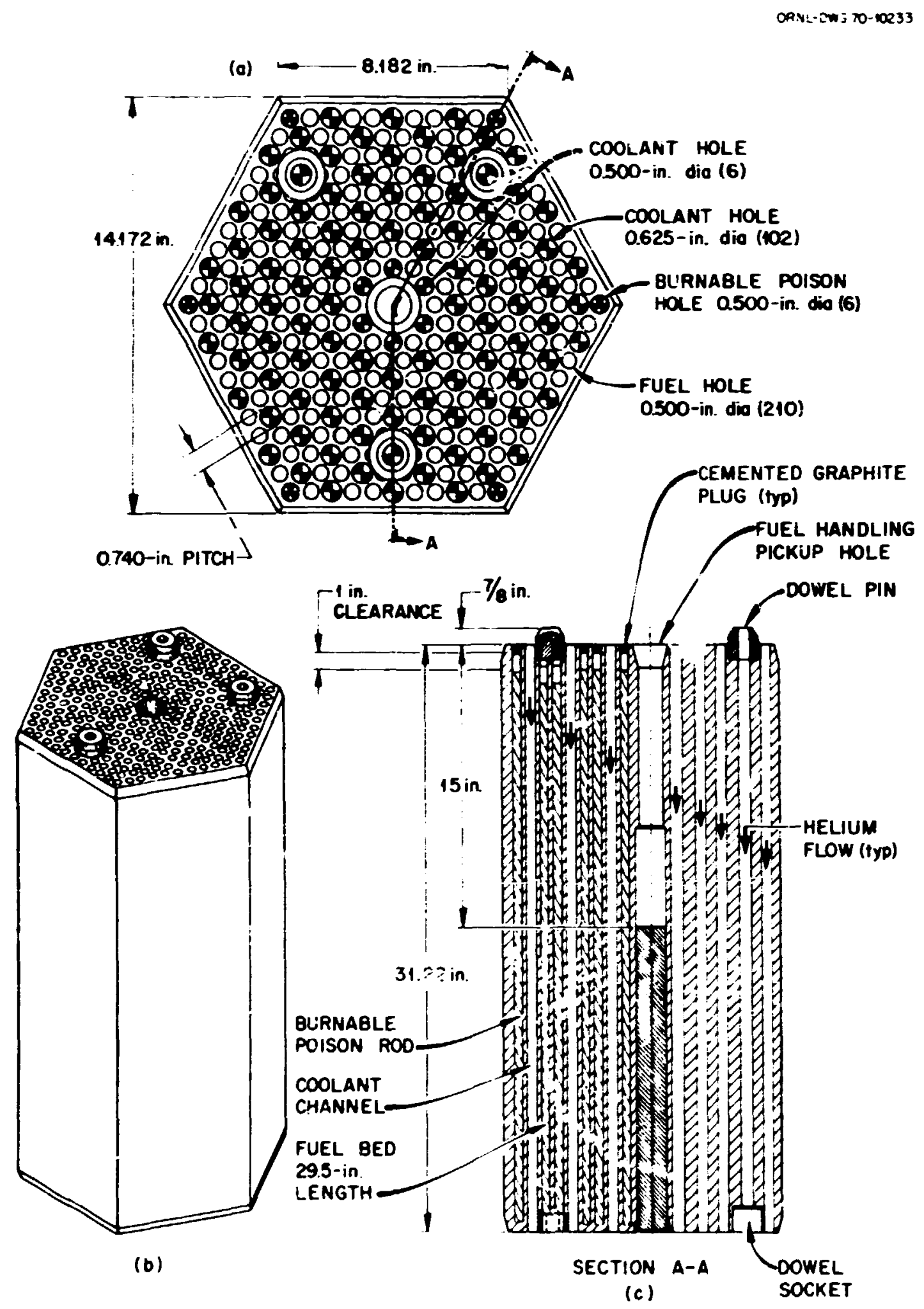

Fis. 1. Typical Fort St. Vrain Active Core Element. 


\section{CARBONIZING AND ANNEALING FTRNACE}

A vertical furnace was designed for the carbonization and annealing step in the remote HTGR fuel slement refabrication process. The vertical design, illustrated in Fig. 2, was considered the best configuration with respezt to hot-cell space. From top tc bottom, the furnace proressing chamber is comprised of a charging gate valve, three temperature-controlled heating zones, two cooling zones, and a discharge gate valve. The processing chamber, with an overall length of approximately 203 in- between valve disks, is enclosed with $;$ doukle-wall water-ccoled metal shell wich surrounds the heating elements and insulation in the heating zones and provides containment in the ccoling zones for the inert atmosphere maintained within the chamber.

The overall height of the furnace is increased about $52 \mathrm{in.}+\mathrm{y}$ the discharge chamber located below the discharge valve. This chamber provides additional cooling for fuel elements leaving the processing chamber ani serves as a double-port lock to maintain the inert atmosphere in the furnace processing chamber during discharging and unloadiag of fuel elements.

The furnace can accommodate a maximum of six fuel elements and seven spacer pailets at any one time. Fuel elements travel downward through the furnace at an essentially continuous ate, and the furnace is furged continuously with argon gas in a flow path opfosite the downard movement of the fuel elemen... The furn-c.? has a design processing capacity of about 14 elements a foy, and its operacion and thermal des.gn are discussed in the fol owing subsections.

\section{Furnace Opiration}

A fuel element and its attendént space: pallet are -b" "Jduceu into the furnace processing chamber from a portable charging chamber seated on the upper face of the charging valve. A pallet is placed on top of each element introduced into she furnace to receive the next element 


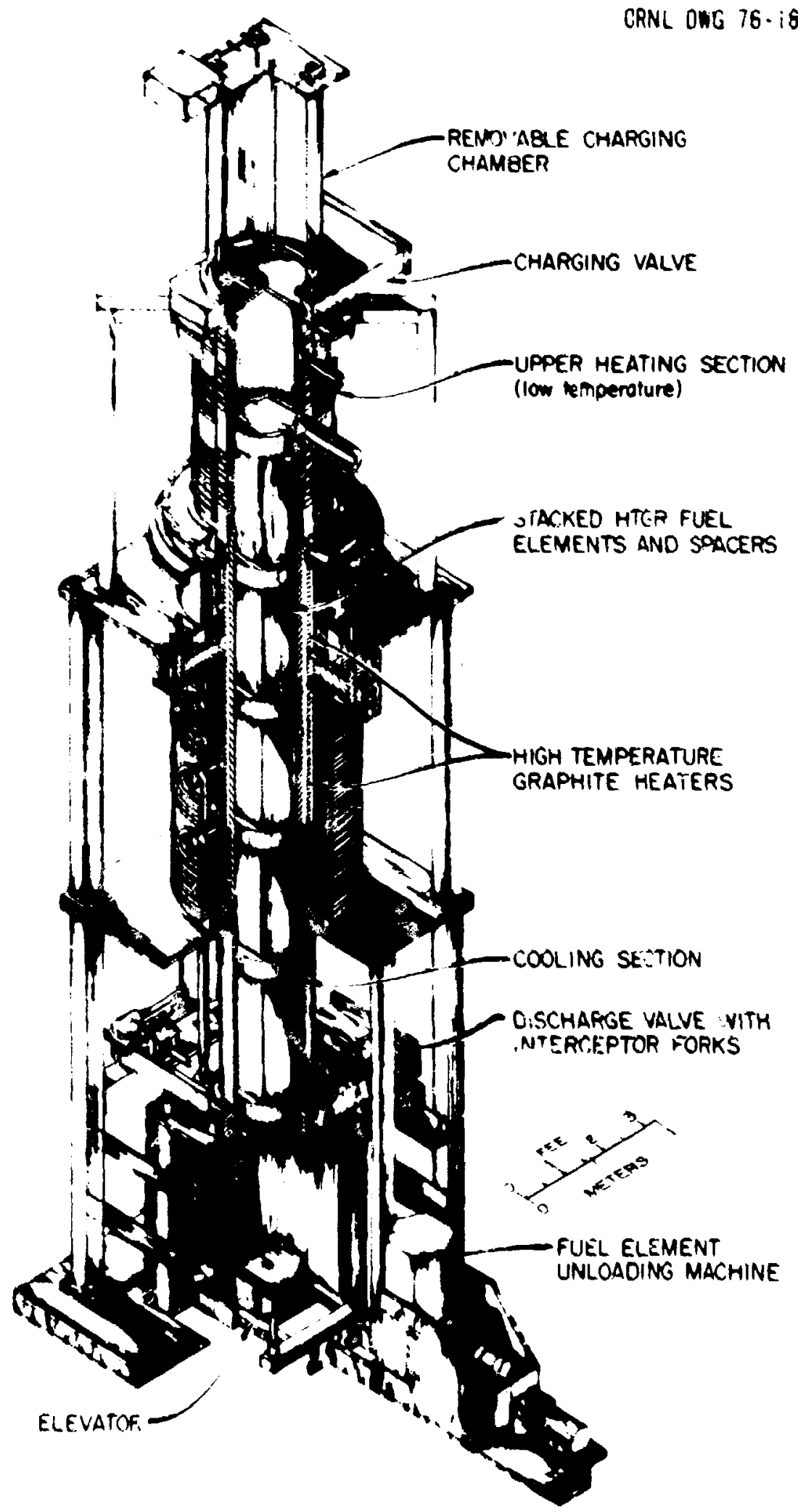

Fig. 2. Proposed HTGR Fuel filc..ent Vertical Cárbonizing and Annealing furnace. 
introduced. This space pallet is a 5-in.-thick clrcular disk with a hexagonally shaped socket about $1.5 \mathrm{in}$. deep $\mathrm{mllled}$ into each face to fit the tops and bcttoms of fuel elements. The :-za.-thick hexagonal web of each pallet is drilled to match the 109 coolant passages of the fuel elements. The seated ch rging chamber is purged with argon, the upper valve gate is opened, and the charging chamber hoist is driven dormward to introduce the element and pa!let into the processing chamber. The bottom of the element is seated in the pallet resting on top of the fucl element be low it in the processing chamber.

The entire column of elemerts and pallets is supported on a motordriven elevator platform in the discharge chamber. This elevator controls the downward movement of the elements through the furnace heating and cooling zones to the bottom of the discharge chamber. When the spacer pallet on top of the bot $\mathrm{cm}$ element in the column is a prescribed disiance above the horizortally retractable support forks, which are wunted in the housing of the furnace discharge valve immediately above the valve disk, the downward movement of the elevator is continued while the forks are inved inward under the pallet. These forks provide interim support for the column of elements and pallets above while the bottom element is lowered by the clevator to the bottom of the discharge chamber. The discharge value is closed, the unloading door in the discharge chamber is opened, and the fuel element and its supporting pallet are removed from the furnace. The unloading door is then closed and the discharge chamber is purged with argon, the discharge valve is opened, and the elevator platform is raised to again support the column of elements ard pallets in the processing chamber. The support firks are retracted, the downward travel of the column is resumed, another fuel elemelt is charged into the top of the furnace processing chamber, and the cycle is repeated.

A furnace cycle begins with what can be termed a "top-loaded" configuration consisting of six elements and seven pallets over the distance marked " $\mathrm{A}$ " in Fig. 3. About 90 minutes later, each ciement has mov A down to comprise the "bottom-loaded" configuration over the distance marked " $B$ " In Fig. 3. Production considerations led to the use of an average element movement of $3 / 8 \mathrm{in}$. per minute. Based on in element length of $31.22 \mathrm{in}$. And a pallet web thickness of about $2 \mathrm{in.}$, the 


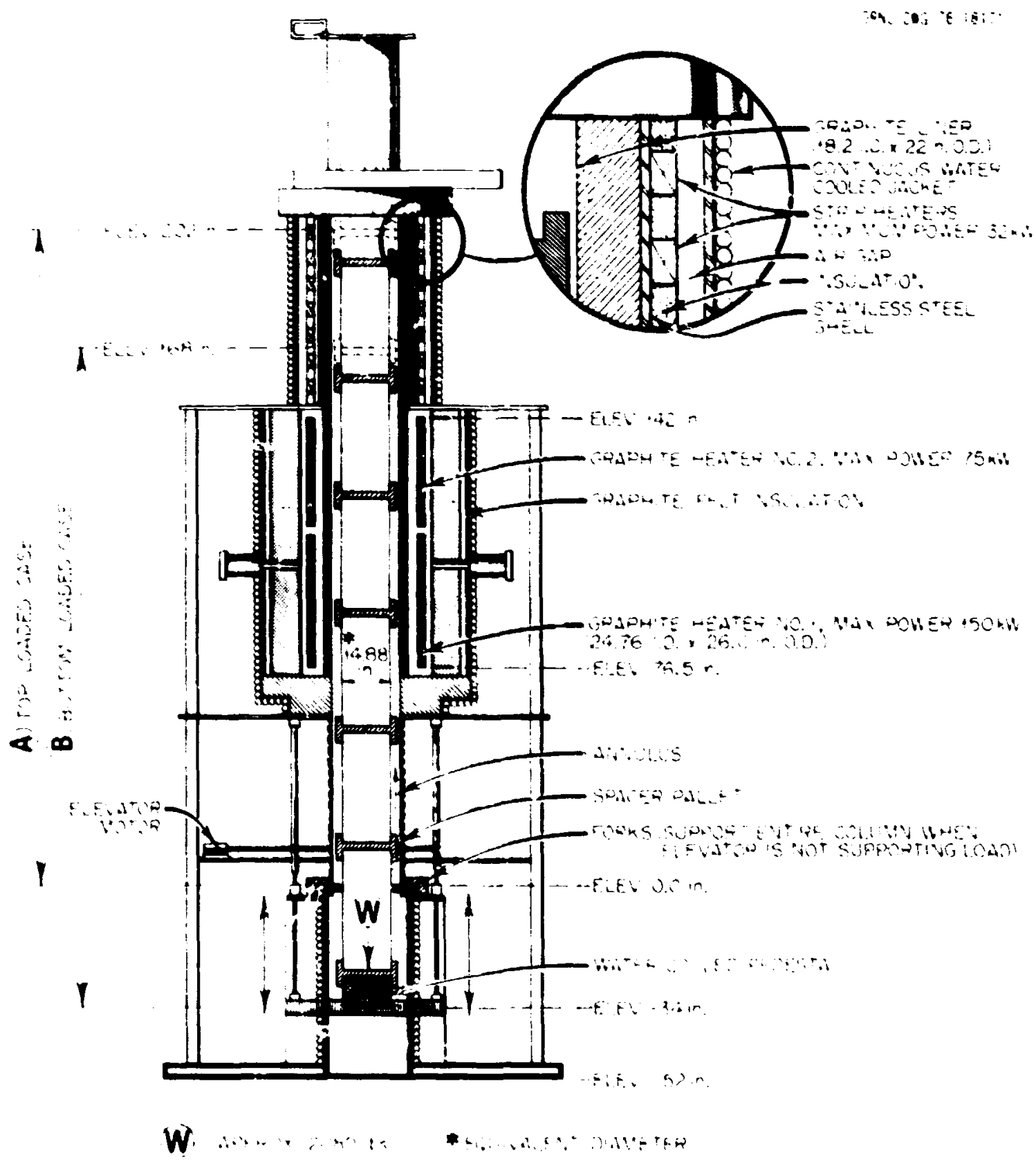

Fig. 3. Operational Diagram of Furnace Design. 
travel time for a complete element unit from the top-loaded to the bottom-losded configuration is 88.6 minutes. About 10 minutes more are requited for unloading and loajing procedures, resulting in an average production rate of about 14 fuel elements per day. However, the thermal analysis reported herein was based on the assumption of continuous mass wovement of $3 / 8 \mathrm{in}$. per minute.

\section{Thermal Design}

The thermal criteria for carbonization of the HTGR fuel rods in place in the graphite blocks stipulate heating of the blocks from $300^{\circ} \mathrm{C}$ to $800^{\circ} \mathrm{C}$ at a constant heating rate not to exceed $10^{\circ} \mathrm{C}$ per minute. A uniform theimal gradient of $26.07^{\circ} \mathrm{C}$ per inch $\left(48^{\circ} \mathrm{F}\right.$ per inch) was obtained by dividing the heating rate $\left(10^{\circ} \mathrm{C} / \mathrm{min}\right.$.) hy the mass movement rate $(0.375$ in./min). This information and the annealing criteria were adequate to establish the desired fumace axial temperature profile illustrated in Fig. 4 .

Point $A$ on the curve shown in Fig. 4 is the temperature at the top of the fuel element unit (element plus spacer pallet) or block introduced into the furnace processing chamber at elevation $202 \mathrm{in.}$, and Point B is the temperature at the bottom of that element at furnace elevation 168 in. Print $C$ denotes the beginning of the critical gradient at a temperature of $300^{\circ} \mathrm{C}$ and a furnace elevation of $142 \mathrm{in.}$, and Point $D$ denotes th. end of the critical zone at a temperature of $800^{\circ} \mathrm{C}$ and a furnace elevation of $123.25 \mathrm{in}$. The temperature gradient used for carbonization was maintained during annealing to obtain the location of Point $E$ at a temperature of $1750^{\circ} \mathrm{C}$ and furnace elevation of $87.63 \mathrm{in}$. Point $F$, the inflection point of the gradients, is the maximum temperature of $1800^{\circ} \mathrm{C}$ reached at furnace elevation $81 \mathrm{in.}$. Any zone above this point requires net heating, while any zone below it requires net cooling.

Point $G$ on the curve is symmetrically adjecent to Point $E$ at a temperature of $1750^{\circ} \mathrm{C}$ and a furnace elevation of $74.37 \mathrm{in}$. A heat balance must be achloved and, although it does not have to be, Point $H$ was conveniently located at furnace elevation $40 \mathrm{in.}$, resulting in a temperature 


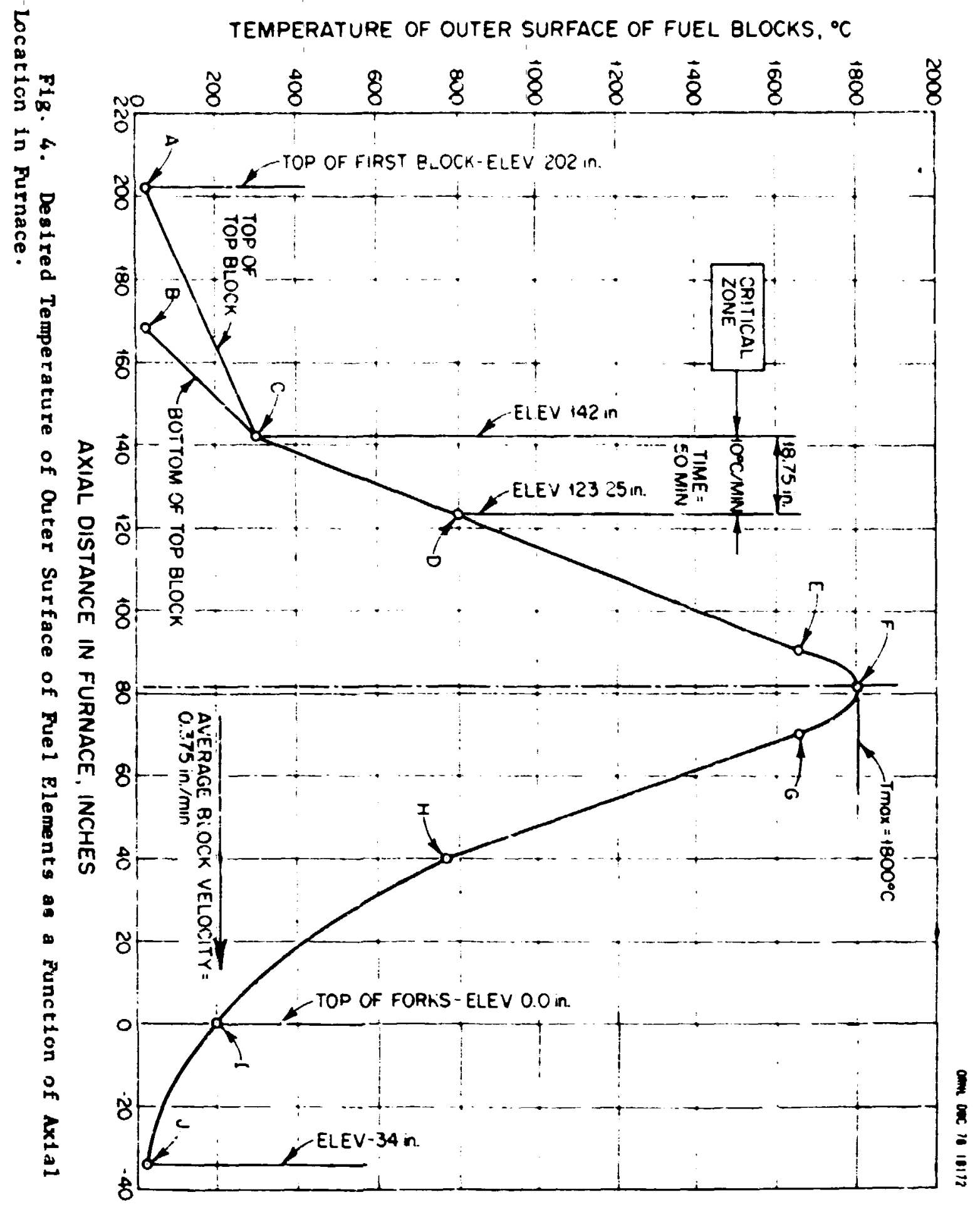


of $770^{\circ} \mathrm{C}$. Point I denotes the desired temperature of $200^{\circ} \mathrm{C}$ at furnace elevation 0 in., while Point $J$ derwtes the ambient temperature of $25^{\circ} \mathrm{C}$ at furnace elevation $-34 \mathrm{in}$.

As previously discussed, the thermal criteria for carbonization of the fuel rods specify a beginning minimum temperature of $300^{\circ} \mathrm{C}$. However, if the temperature in the uppermost portion of the furnace rocessing chamber were permitted to exceed $300^{\circ} \mathrm{C}$, the gasket used in the charging valve would fail. If the temperature of the surface of the charging valve Internal to the processing chamber were allowed to fall below $200^{\circ} \mathrm{C}$, hydrocarbons would condense out on this surface. The furnace was therefore designed to provide an axial temperature profile ranging from $200^{\circ} \mathrm{C}$ in the upper section up to a maximum temperature of $1800^{\circ} \mathrm{C}$ in the center section and back down to a temperature of $200^{\circ} \mathrm{C}$ in the bottom section, with the temperature range up to about $800^{\circ} \mathrm{C}$ for carbonization and that between 800 and $1800^{\circ} \mathrm{C}$ for annealing.

Attainment of the desired axial temperature profile within the furnace processing chamber, and thus in the fuel elements, is based on the provision of three controlled heating zones, each designed to increase the temperature of a fuel element by a differing amount, and three cooling zones. Two of the cooling zones are within the furnace processing chamber (above the discharge valve), and the third is the discharge chamber below the processing chumber. Completion of the processing of an element in the furnace is a function of time and temperature in the various zones.

The first controljed heating zone in the furnace processing chamber below the charging valve, the low-temperature heating zone, is approximately 60 in. long and is heated with metallic strip heating elements interspersed with ceramic fiber insulation. When first introduced into the fumace processing chamber, a fuel element will be at hot-call ambient temperature, which will be about $25^{\circ} \mathrm{C}$. Upon leaving the low-temperature heating zone and entering the intermediate-temperature heating zone, the fuel element is expected to have an outer surface temperature of approximately $300^{\circ} \mathrm{C}$. As indicated in Fig. 4, the temperature of the outer surface of the bottom of the fuel element is expected to increese from $25^{\circ} \mathrm{C}$ to $300^{\circ} \mathrm{C}$ in approximate ly $26 \mathrm{in}$. of travel. At $0.375 \mathrm{in}$. per minute, this would amount to an increase of about $4^{\circ} \mathrm{C}$ per minute. 
The intermediate-temperature zone in the processing chmber is heated by a graphite resistance heater about 22 in. long th.3t is surrounded with insulation. The evolution of volatiles from the pitch bondIng material in the fuel rods (carbonization) will begin at a temperature of about $300^{\circ} \mathrm{C}$ and will be completed at temperature of about $800^{\circ} \mathrm{C}$. The coke yield, atrix-particle interaction, and resulting quality of the rods in each element are dependent upon the heating rate in the carbonization range $\left(300\right.$ to $\left.800^{\circ} \mathrm{C}\right)$. The critical heatjng rate in the intermediate terperature zone mist be maintained at near $10^{\circ} \mathrm{C}$ per minute, and carbonization is expected to be completed when the fuel element leaves this heatIng zone with a surface temperature of about $800^{\circ} \mathrm{C}$.

A fuel element leaving the intermediate-temperature zone enters the third (high-temperature) heating zone wherein the fuel rods are annealed in place in the element. A graphite resistance heating element about 43.5 in. Iong surrounded with insulation is used in the high-temperature zone to attain the maximum element surface temperature of $1300^{\circ} \mathrm{C}$ required to remove the last traces of volatiles and produce dimensionally $8 \pm a b l e$ fuel rods. The heating zate in the annealing zone is not critical. Once the maximum temperature has been reached, the temperacure $c f$ the fuel element will be lowered as rapidly as possible. The surface temperature of an elerent is expected to already have begun falling from the $1800^{\circ} \mathrm{C}$ maxinum as the element leaves the high-temperature heating zone and enters the high-temperature cooling zone.

Graphite is used in the high-temperature cooling zone, which is about 26 in. long, to conduct heat to the water-cooled surface of the processing chamber, thereby reducing the temperature of the fuel element as it progresses through the zone. It is estimated that the temperature of an element will be about $1050^{\circ} \mathrm{C}$ as it laves the first cooling zone and enters the second or low-temperature cooling zone. The water-cooled surface of the chamber is in close proximity to a fuel element as it progresses through the 50-in. long low-temperature cooling zone. It is estimated that the surface temperature of the fuel element will be between 200 and $400^{\circ} \mathrm{C}$ as the element leaves the low-temperature cooling sone and enters tile discharge chamber, which serves as the final cooling zone. The temperature of the element is expected to be reduced to at least $200^{\circ} \mathrm{C}$ during the time it is retained in the discharge chamber prior to unlouding. 
The radial thermal gradient in the column of fiel elements will also rary along the vertissl iength $: \dot{r}$ che furnace. The radial gradieut is expected to be at a minimum in tie center of the colum of fuel elements at mid-cycle. At the top of the column, the temperature at the center of an element gisould be less than that at the outer surface, while the temperature at the center is expected to be higher than tinat at the surface of an element at the bottow of the column. The temperature of the outer surface of an element in the intermediate-temperature heating zone, wherein carbonization takes place, is expected to be slightly higher than that at the center of the element. This means that the surface of an element subjected to the "critical-zone" temperature increase will reach the desired $800^{\circ} \mathrm{C}$ temperature sooner than the center of an element. It is estimated that the temperature 1 ag will be less than $50^{\circ} \mathrm{C}$. 


\section{ENERGY TRANSPORT SIMULATION IN THE MOVING COUUN}

The basic problem in performing a thermal analysis of the furrace design was to determine how the heating and cooling should be distributed in the moving column $=\bar{f}$ fuel elements to ackieve a Gaussian temperature profile along the axis of the column. In a simple analogy, the colurn of fue 1 elements and spacer pallets can be thought of as a rod. If the rod were stationary, it could be heated at its mid-point with a single heating zone and cooled at both ends to achieve the desired axial temperature profile. The heaters would be insulated on the outside to curtail heat losses. However, when the rod is moving, nore heat must be added in the heating zone to account for the heat absorbed by the moving mass and more cooling must be provided in the downstream cooling zone to account for the teat released by that mass.

The material properties of the graphite spacer pallets were assumed to be this same as those of the fuel. elements. On the basis of an avarage element weight of $295 \mathrm{lb}$ and an assumed pallet weight of $40 \mathrm{lb}$, the column of elements and pallets in the furnace will weigh approximately $10.08 \mathrm{lb}$ per linear inch. At an average mass flow rate of $3 / 8 \mathrm{in}$. per minute, the furnace will process 3.78 lb of graphite a minute but only about $88 \%$ of this weight will be comprised of element material.

If a mean value of $0.33 \mathrm{Btu} / 1 \mathrm{~b} \cdot{ }^{\circ} \mathrm{F}$ is assumed as the specific heat of the moving column of graphite in the furnace, about $70 \mathrm{~kW}$ of power will be required to provide the heat absorbed by this mass movement. Continuirg the simplified analogy, heat would be lost at both ends of the moving rod by conduction. This would annunt to about $5 \mathrm{~kW}$ at the top and about $4.7 \mathrm{kH}$ at the bottom. To this, heat must also be added to account for that lost by the heaters through the furnace insulation. This radial heat loss was estimated at about $10 \mathrm{~kW}$. Thus, a rough estimate of the total power required for the furnace is about $90 \mathrm{~kW}$. These estimated values indicate that the axtal heat loss resulting from mass flow will be about seven times the loss from conduction and about $77.8 \%$ of the total heat input. Simulation of the mass movanert is therefre quite important in obtaining a realistic solution to a stesdy-state analysis of the furnace. 


\section{Determination of Volumetric Heat Generation Rate}

The amount of heat required to account for that given up or lost by the mass movement of graphite elements and pallets through the furnace was determined by evaluating an internal heat generation rate duplicating the mass flow loss. A negative heat generation rate was applied at the top of the furnace above elevation $81.0 \mathrm{in.,}$ and a positive heat generation rate was used below this elevation for both the top- and bottomloaded configurations 1.1 lustrated in Fig. 3 .

Argon gas is to be introduced at the bottom of the furnace at an upward flow rate of $7.0 \mathrm{scfm}$ and a temperature of $25^{\circ} \mathrm{C}$. A flow of $5.0 \mathrm{scfm}$ will be maintained through the fuel element coolant chanrels via distribution channels mactined in the horizontal surfaces of the spacer pallets. The remaining $2.0 \mathrm{scfm}$ of argen will fiow through tive annular space between the colum of fuel elements and the furnace processing chamber liner. A total of about 6 scfm of argon gas will be in contact with the elements, and the total hea: capacity of the fiowing gas is about $4.35 \mathrm{~kW}$. The gas will be moving at an average velocity of about $C .333 \mathrm{ft}$ per seinnd $w$ : h a mass flow rate of $0.6204 \mathrm{lb} /$ minute and a mass veiocity of $122 \mathrm{lb} / \mathrm{h}$ iur $\cdot \mathrm{ft}^{2}$. The resulting heat transfer coefficient is 1 ese than $2.0 \mathrm{Btu} / \mathrm{hr} \cdot \mathrm{ft}^{2} \cdot{ }^{\circ} \mathrm{F}$, and this linits the mean difference betwee', the temperature of the argon gas and the fuel elements to about $25^{\circ} \mathrm{\sim}$. Since the direction of the gas movement in the furnace will be opposite that of the elements, the heat from the argon mass flow was subtractec. Instead of acting as a heat sink, the gas will act as a distributor of heat. As for the fuel element movement, the volumetric heat generation rate at each increment will pro vide for the heat transport assuriated with the flow of argon gas.

The equation used to determine the net incremental volumetric heat generation rate is as follows.

$$
q_{i}^{\prime \prime \prime}=\left(Q w_{1}-Q A_{i}\right) / A_{x},
$$

where

$$
\begin{aligned}
& q_{f}^{\prime \prime \prime}=\text { net incremental volumetric heat generation rate, Btu/min.in. }{ }^{3} \text {, } \\
& Q W_{i}=\text { heat input per unit length from mass movement of fuel elements, }
\end{aligned}
$$


$Q A_{1}=$ heat input per unit length from mass flow of argon gas, Btu/min.in., and

$A_{x}=$ cross-sectional area oi fuel element $=173.93 \mathrm{in} \cdot{ }^{2} / \mathrm{in}$.

The heat input resulting from the mor 3 movement of fuel elements

$$
Q w_{1}=w_{8} C_{8}(d T / d z)_{1} \text {. }
$$

where

$$
\begin{aligned}
w_{g} & =\text { mass flow rate of fuel elements }=3.78 \mathrm{lb} / \mathrm{min}, \\
C_{g} & =\text { specific heat of unirradiated fue } \mathrm{j}=\text {, went composites } \\
& =\mathrm{f}_{1}(\overline{\mathrm{T}}) \mathrm{Btu} / \mathrm{lb} \cdot{ }^{\circ} \mathrm{F} \\
& \text { where } \overline{\mathrm{T}}=\text { mean temperatur. of increment in }{ }^{\circ} \mathrm{F} \text {, and } \\
(\mathrm{dT} / \mathrm{dz})_{1} & =\text { incremental axial thermal gradient in fuel elements } \\
& =\mathrm{f}_{2}(\mathrm{z})=\mathrm{d}(\mathrm{T} / \mathrm{z})_{\mathrm{i}} .
\end{aligned}
$$

The incremental axial thermal gradients were determined from data illustrated in Figs. A.1 and $\mathbf{1 . 2}$ in Appendix $A$ for the top-loaded furnace configuration and Figs. A.8 and A.9 for the bottom-loaded configuration. These figures show modified profiles of the temperature distribution on the surface of the column of graphite elements and pallets in the topand bottom-loaded furnace configurations. The desired temperature profile illustrated in Fig. 4 was used as a guide for these curves. Since inflections cannot be obtained in a real system, smooth functions were used to generate the more realistic temperature criteria profiles shown In Figs. A.1, A.2, A.8, and A.9. These profiles were broken dcin into poiynomial functions of the sixth order or less, and it was a simple matter to obtain the derivatives of ihe functions to evaluate the desired incremental quantities.

The heat input resuliting from the mass flow of argon gas

where

$$
Q A_{1}=w_{a} C_{a}(d T / d z)_{1} \text {, }
$$

$$
\begin{aligned}
& w_{a}=\text { mass flow rate of argon gas }=0.607 \mathrm{lb} / \mathrm{minute} \text { and } \\
& C_{a}=\text { specific heat of argon gas }=0.125 \mathrm{Btu} / \mathrm{lb} \cdot{ }^{\circ} \mathrm{F} .
\end{aligned}
$$




\section{Heat Balance ir. Graphite Column}

A heat balance was made on incremental sections of the column of fuel elements and spacer pallets as encountered in the furnace. The heat inputs from the first and last increments wer? obtained from the prevailing boundary conditions. The heat entering the second increment by the process of conduction and mass flow of both the graphite and argon was subtracted from the sumation for the first increment. The difference is the result of either an external heat input or rejection, depending on the sign. Successive summations were made over the complete range of the fuel elements to obtain the net external heat requirements.

An attempt to perform this heat balance manually by using rather large increments caused anomalies in the plots. The calculations were programed and processed on the computer with much better results. Different heating and cooling rates resulted from not including the heat lost from the heaters through external surfaces of the furnace in the calculations. The difference between the heating and cooling requirements provides a rough estinate of this loss.

The incremental heat input per unit length crom external sources resuiting from conduction in the axial direction

$$
Q X_{i}=\left(Q C_{i+1 / 2}-Q C_{i-1 / 2}\right) / d z_{i} \text {, }
$$

where

$$
\begin{aligned}
& \mathrm{QC}_{\mathrm{i}+1 / 2}=\text { heat flow across increment by conduction } \\
& =-k_{\varepsilon}{ }^{d}(\mathrm{dT} / \mathrm{dz})_{i+1 / 2} \text {, } \\
& Q C_{i-1 / 2}=-k_{8} A_{x}(d T / d z)_{i-1 / 2} \text {, and } \\
& \begin{aligned}
k_{g}= & \text { axsal thermal conductivity of specified fuel element } \\
& \text { composite, Btu/min.ft }{ }^{\circ} \mathrm{F} \text {. }
\end{aligned}
\end{aligned}
$$

The-ofore,

$$
\begin{aligned}
Q_{1} & =-k_{8} A_{x}\left[(d T / d z)_{i+1}-(d T / d z)_{i-1} ? / d z_{i}\right. \\
& =-k_{8}{ }^{A}{ }_{x}\left(d^{2} T / d z^{2}\right)_{i} .
\end{aligned}
$$

The equations used to perform the heat balance expressed the total heat per unit leigth (QT) supplied to each increment(i) from an external scurce 19 follow. 


$$
Q T_{i}=Q N_{1}+Q X_{i}-Q A_{i} \text {. }
$$

The pertinent quantities were calculated for each increment of the topand bottom-loaded configurations of the furnace. The results for fuel element units or composites fabricated from H-327 graphite as a function of axial position in the furnace for the top-loaded configuration are given iñ Idule A.l of Appendix A, and those for the bottom-loaded configuration are given in Table A.2. Comparable data for fuel element composites fabricated from $\mathrm{H}-451$ graphite are given In Tables B.1 and B.2 in Appendix B.

A graphics subroutine was written to plot the output data, and the resulting plots for the fuel element composites fabricated from $\mathrm{H}-327$ graphite are shown in Appendix $A$. The axial heat transfer resulting from the mass flow of fuel elements is shown in Fig. A.3, that from conduction in fuel elements is shown in Fig. A.4, and the axial heat transfer from the mass flow of argo gas is shown in Fig. A.5. The sum of the heat input by all mechanisms is shown in Fig. A.6, which gives a good idea of the power distribution required to produce the desired temperature distribution. The composite axial power distritution for the top-loaded furnace configuration is shown in Fig. A.7. Comparable data for the bottom-loaded configuration are shown in Figs. A.10 through A.14.

The internal volumetric heat generation rate required for simulation of the mass movement of fuel elements fabricated from $\mathrm{H}-327$ graphite is illustrated in Fig. 5 for the top-loaded furnace configuration and in Fig. 6 for the bottom-loaded configiration. se data are required as input to the HEATING4 computer program. used to analyze the thermal design of the furnace. Tabular functions were used to put the data in the program to produce the desired internal heat generation for the steady-state analysis. It should be noted that simulation of the mass flow of material using internal heat generation causes a radial gradient in the fuel elements that really is not supposed to be present. This gradient amounts to about $100^{\circ} \mathrm{C}$ at the point of maximum heat generation and practically nothing at the ends of the column of fuel elements and pallets. Therefore, only the temperatures at the outer surfaces of the fue 1 elements were used for temperature comparisons. 


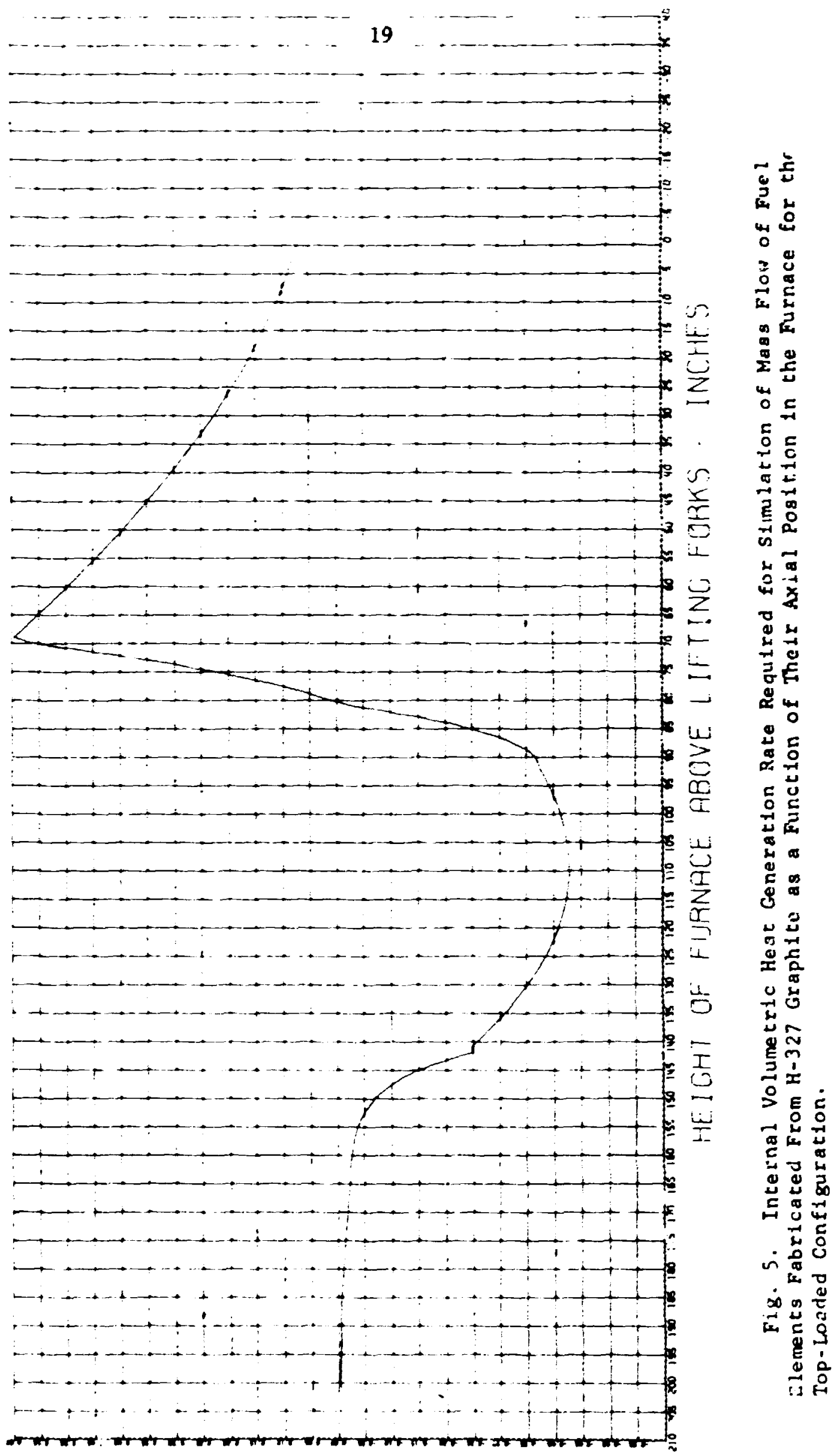

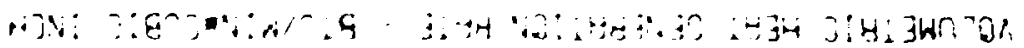




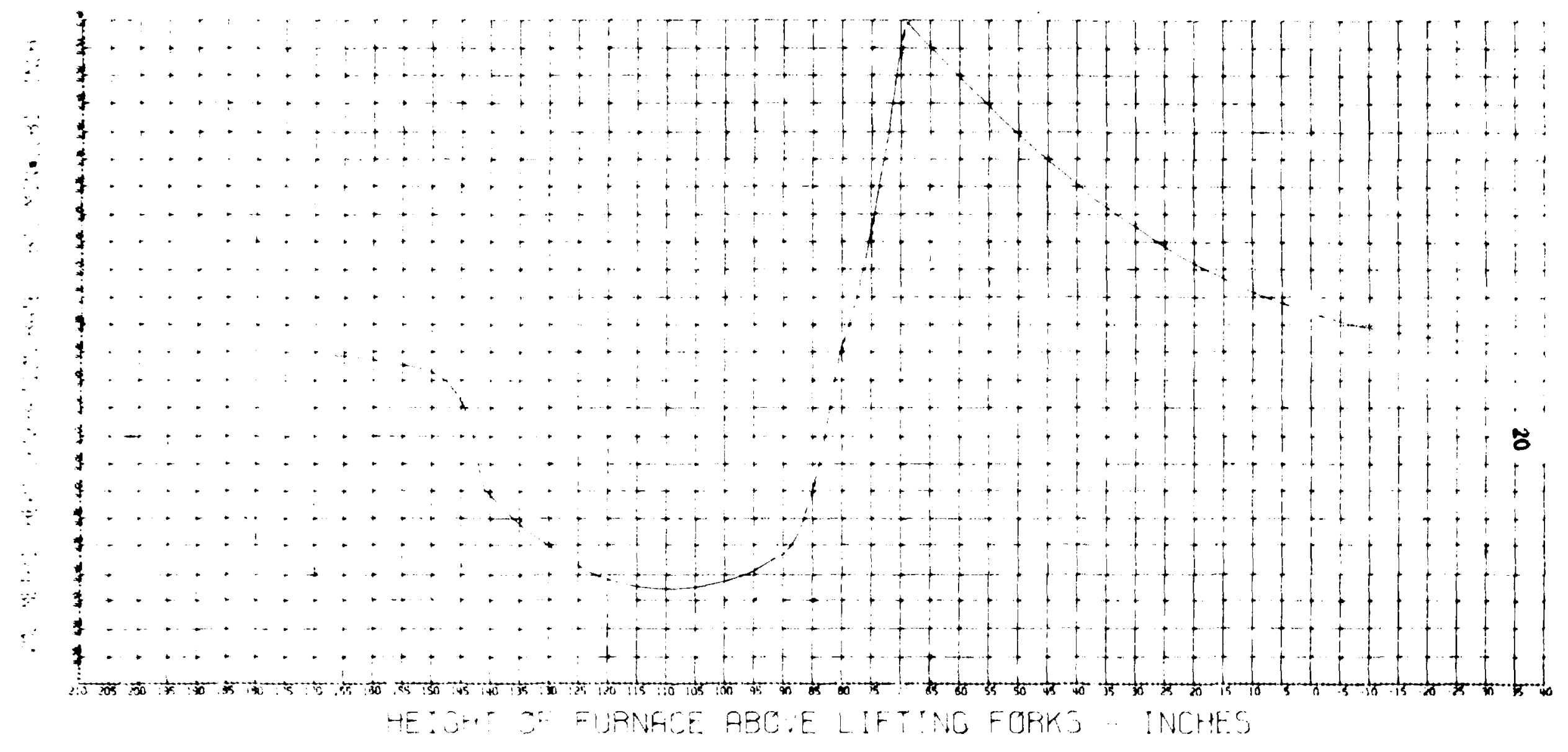

F1g. 6. Internal Volumetric Hea: Generation Rate Required for Simulation of Mass Flow of Fuel Elements Pabricated From $H-327$ Graphite as a Function of Theit Axial Postion in the Furnace for the Bettom-Loaded Conf 1 guration. 


\section{HEAT TRANSFER MODELS AND BOUNDARY CONDITIONS}

The mathematical heat transfer models used in the computer analysis of the thermal design for the HTGR fuel element carbonizing and annealing furnace we formulated from the actual furnace design and the operational diagram 1 llustrated in Fig. 3. To furnace heat transfer mdels were made: one for the top-loaied configuration and the other for the buttomloaded configuration. The top-loaded model, shown in Figs. 7, 8, and ?, contalus 1005 nodes ganerated from 77 regions. (A node is generated at the intersection of bilaceral grid lines.) The colum of fuel elements and spacer pallets extends from about furnace elevation $202 \mathrm{in}$. downard to elevation $0.0 \mathrm{in.}$ in the top-loaded model.

The bottcm-1t aded model, shown in Figs. 1n, 8, and 11, contains 1036 nodes generated by 76 regions. In this model, the column of elements and pallets extends from furnace elevacion $168 \mathrm{in}$. downard to about elevation - $34 \mathrm{In}$. This configuration differs from the top-loaded one only in the extent to wich the column extends into the discharge chamber, with more colum length being exposed to cooling and less to heating.

Both heat transfer models are axisymetric and cylindrical, with the cross-sectional area of the modeled cylindrical fuel element being equal to that of the actual hexagenal element. In both configurations, the column of elements and pallets was assumed co be continuous and unt form. The models were divided into regions, and the data for cach region included its material properties, dimensions, heat generation and initial imperature functions, and boundary conditions. Twenty-four rngions in the heat cransfer models were used to depict furnace heaters.

The low-temperature heating zone in the furnace processing chamber is heated with 16 electric strip heaters, and the regions in the models representing these heaters ware programed individually for internal heat generation. To keep the temperature of the bottom surface of the charging value at the top of the chamber from falling be $10 \mathrm{w} 200^{\circ} \mathrm{C}$, the region depicting the valve gate was programed with internal heat generation representing a heater.

Both the intermediate- and high-temperature heating zones in the furnace procissing chamber are heated electrically with individual, three 


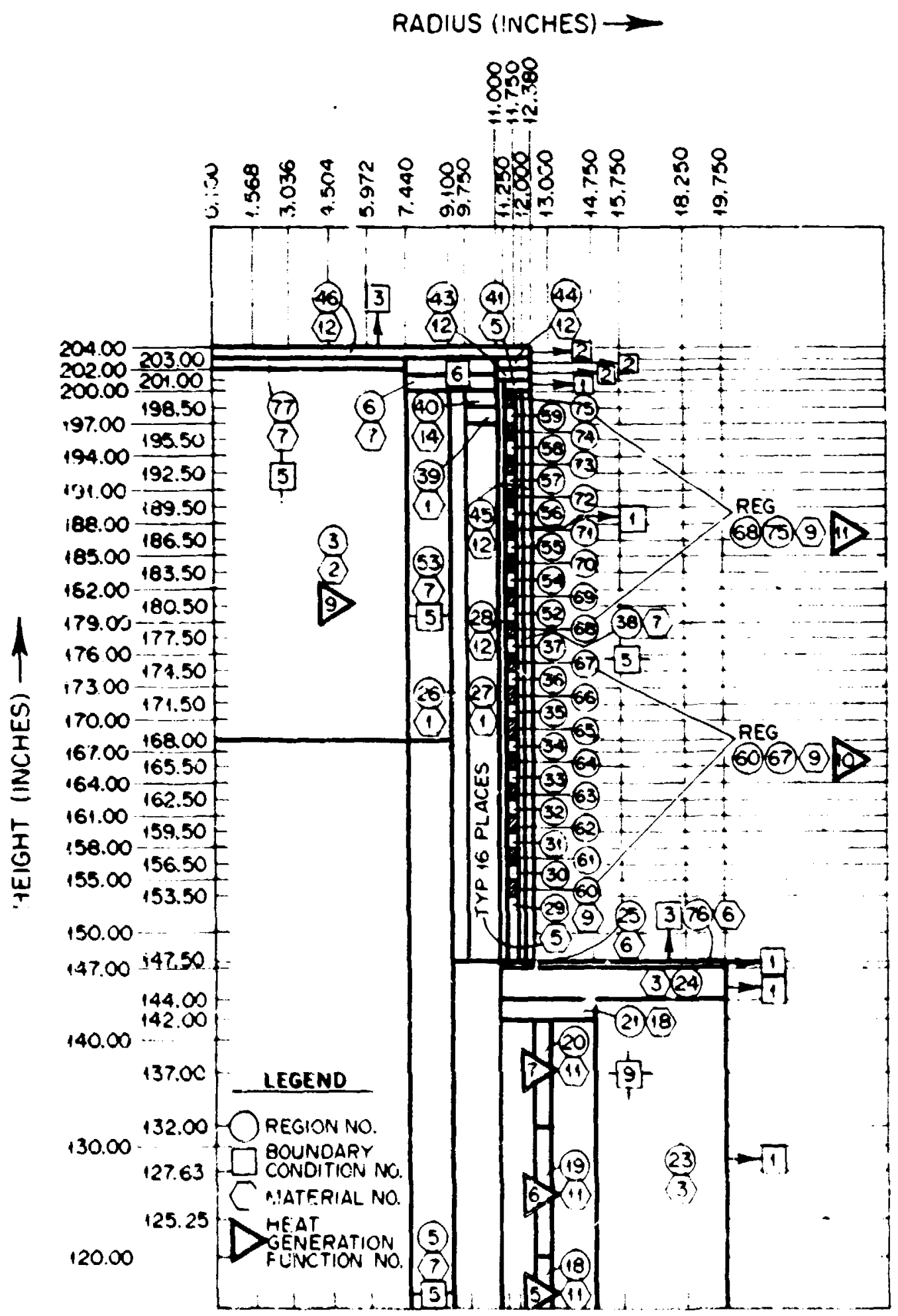

Fig. 7. Computer Model of Upper Portion of Furnace for TopLaded Configuration. 


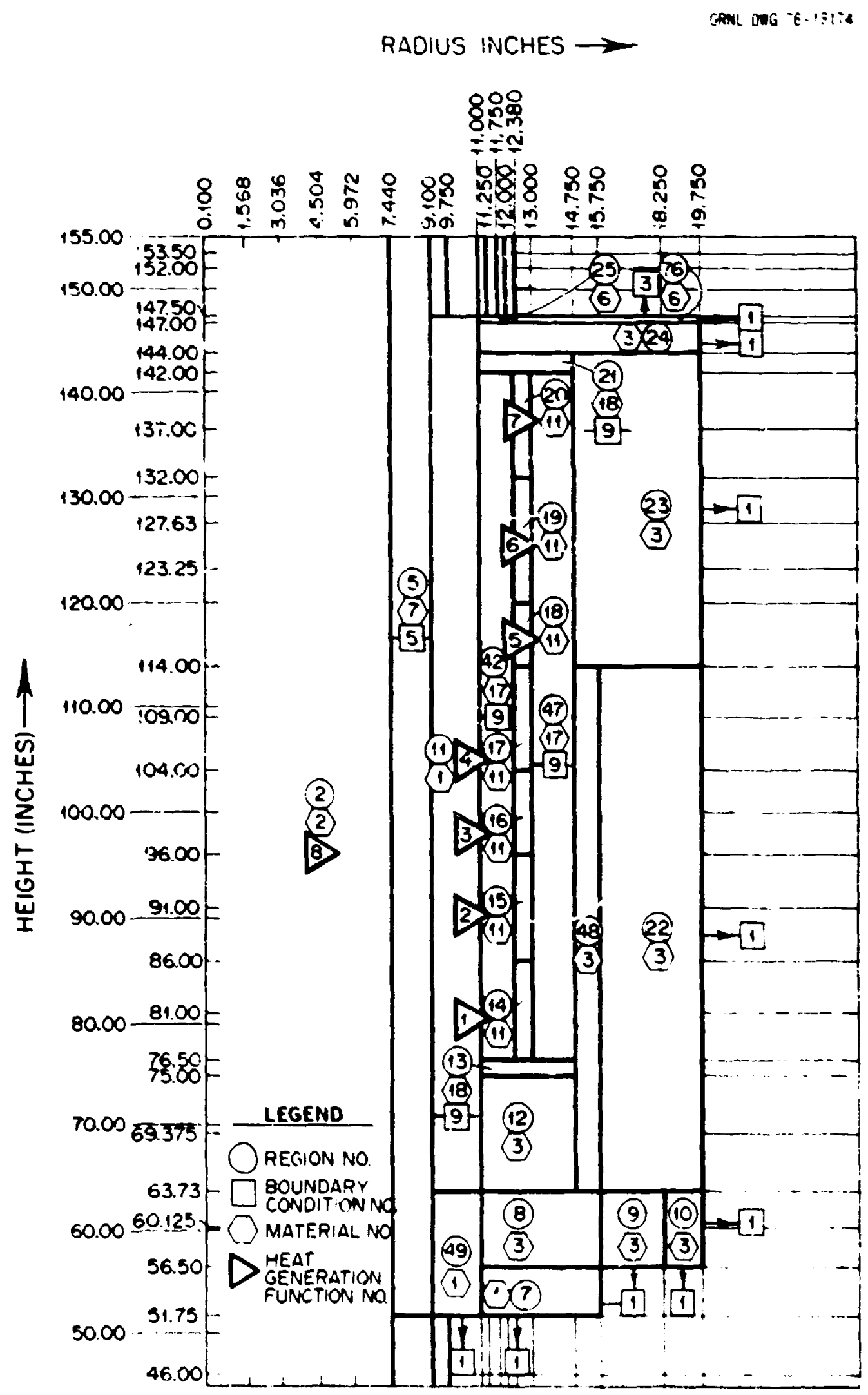

Fig. 8. Computer Model of Middle Portion of Furnace for Topand Bottom-Loaded Configurations. 


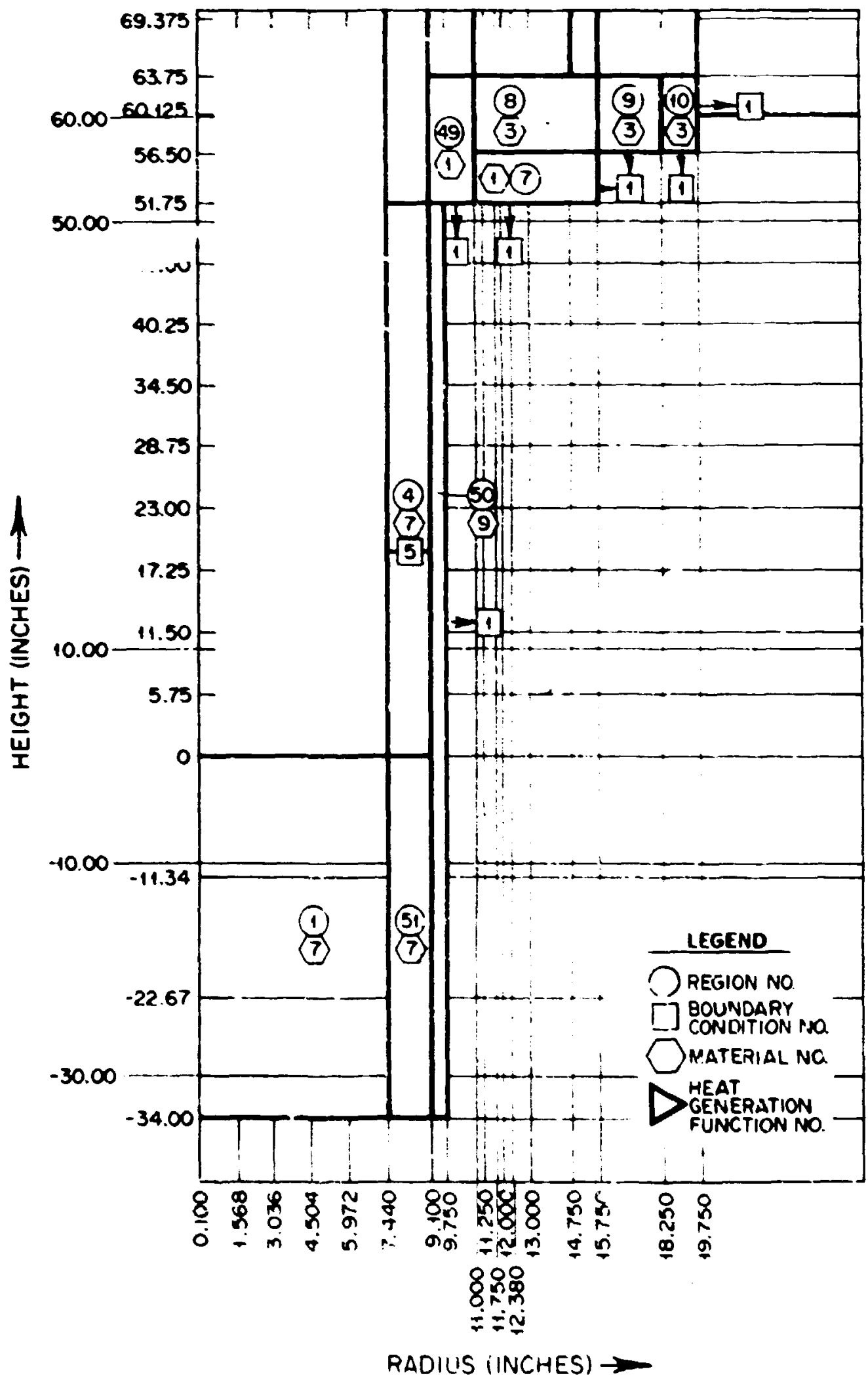

Fig. 9. Computer Model of Lower Portion of Furnace for TopLosded Configuration. 


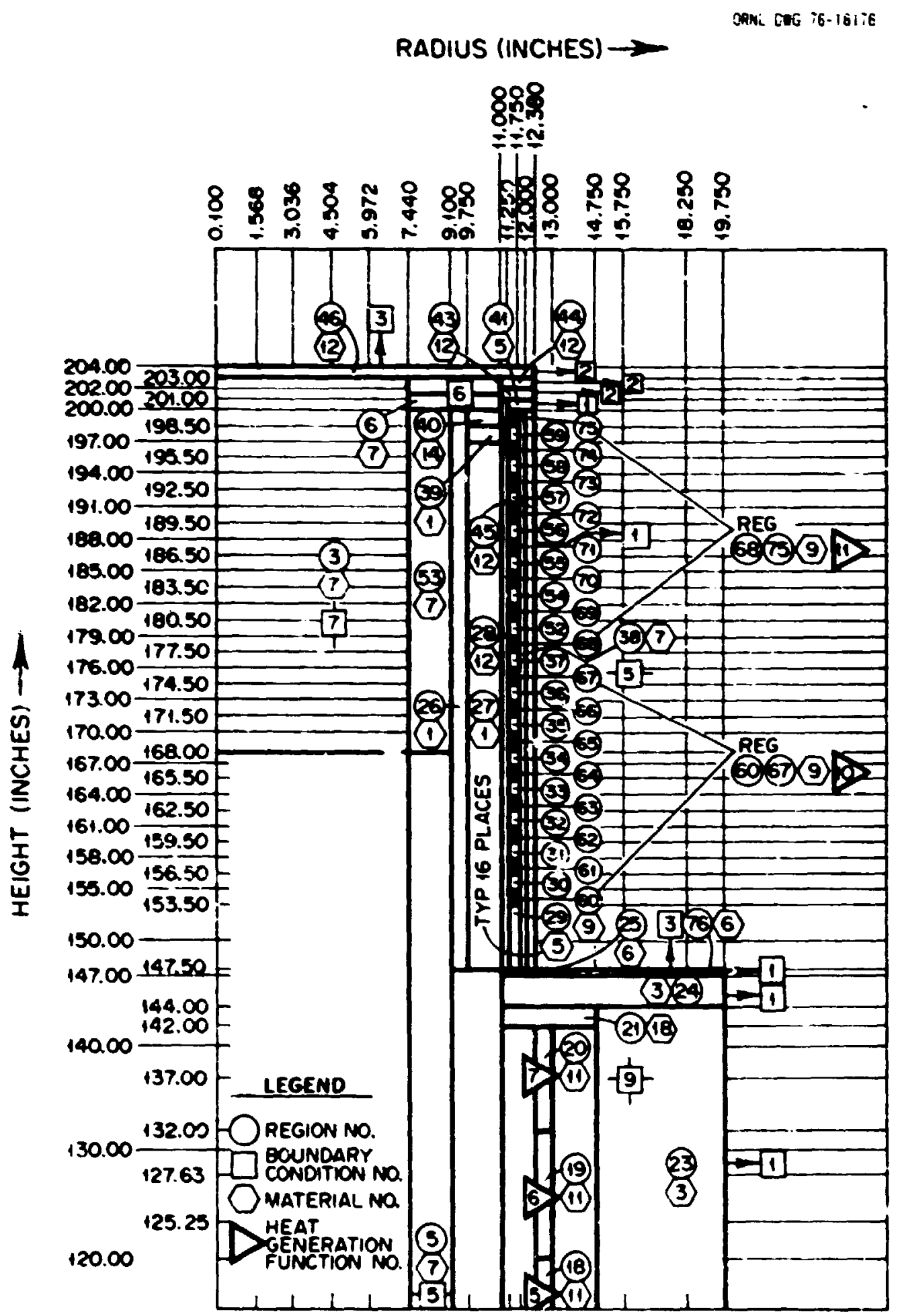

Fig. 10. Computer Model of Upper Portion of Furnace for BottomLaded Configuration. 


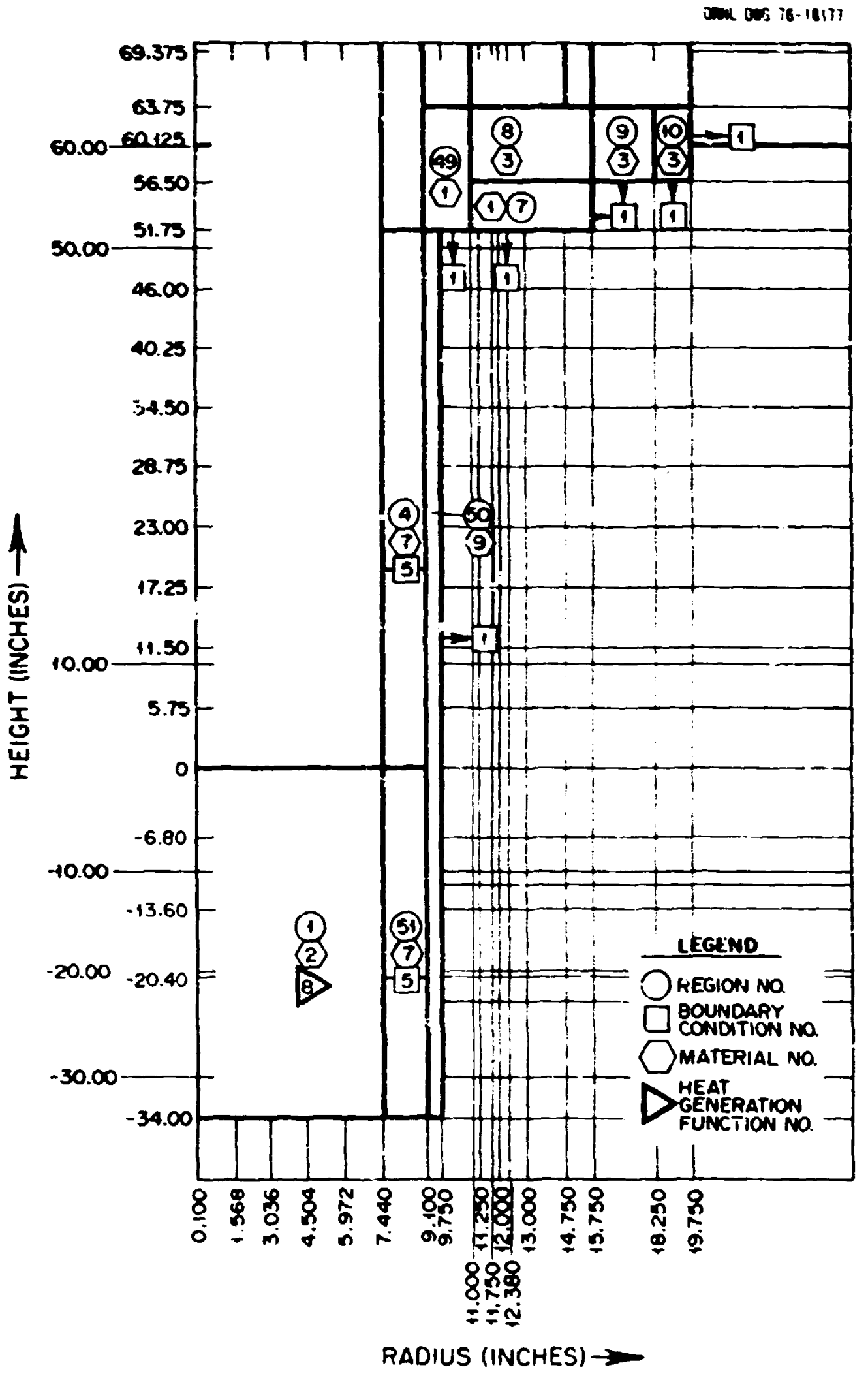

Fig. 11. Computer Model of Lower Portion of Furnace for BottomLoaded Configuration. 
phase, delra-connected graphite beaters supplied by individual circuits. In the heat transfer models, the two graphite heaters are shown in seven regions of internal heat generation. The upper heater, supplying the intermediate-temperature zore, is represented in the models by two regions; while the lower heater, supplying the high-temperature heating zone, is represented by five regions. These regions were based on variations in the cross-sectional area of the heater corductor. Theoretically, it probably would have been better to have used seven separate heaters with individual controls, but bacause of space limitations and complexity, the rower supply to this area of the furnace was limited to two circuits (one for each heater). This means that power cannot be increased in one region of a heater without increasing it proportionately in all other regions of the heater supplied by the same circuit. The cross-sectional area of the conductor can be changed to vary the power distribution in the different regions of heater only within certain linits based on the strength of the graphite.

Several ondes of heat transfer at the furnace boundaries were accounted for in the thermal analysis. Internal heat was expected to be radiated to the bottom surface of the charging val se at the top of the furnace chamber, and as previously. ssed, this surface was assumed to be held at a constant temperature of $200^{\circ} \mathrm{C}$. Internal heat is expected to be transferred by forced convection to cooling surfaces, and it was assumed that these surfaces could be maintained at a constant temperature by using water-cooled plates. The colum of graphite elements and pallets will be cooled directly along water-cooled surface length of about $86 \mathrm{in}$. In the furnace buttom-loaded configuration. The everage heat flix in this configuration is expected to at:ount to about $7000 \mathrm{Btu} / \mathrm{hr} \cdot \mathrm{ft} \mathrm{t}^{2}$, which is normal for this type of cooling.

In the furnace top-loaded configuration, the directly cooled length is reduced to about $52 \mathrm{in.}$. In this configuration, the average heat flux is expected to be about $14,000 \mathrm{Btu} / \mathrm{hr} \cdot \mathrm{ft}^{2}$ at the beginning of the cycle and about $5300 \mathrm{Btu} / \mathrm{hr} \cdot \mathrm{ft}^{2}$ at the end of the cycle then power to the upper (low-temperature) heacers has been reduced. The maximum internal temperature of about $1800^{\circ} \mathrm{C}$ is expected to be reached at a furnace elevation of about $81 \mathrm{in.} \mathrm{Because} \mathrm{of} \mathrm{the} \mathrm{furnace} \mathrm{insulation,} \mathrm{the} \mathrm{heat} \mathrm{flux} \mathrm{on} \mathrm{the}$ 
cooling surface at that location is expected to be about $8000 \mathrm{Bt} / \mathrm{hr} \cdot \mathrm{ft}^{2}$. The maximum heat flux on the cooliriz surface is expected at a furnace elevation of about $51.75 \mathrm{in}$. where the surface is expected to experience temperatures of 700 to $1000^{\circ} \mathrm{C}$, resulting in radiant heat fluxes as high as $40,000 \mathrm{Btu} / \mathrm{hr} \cdot \mathrm{ft}^{2}$.

The difference in these estimated heat fluxes indicates that cooling could be a problem, and it is imperative that the radiation heat exchange to the cooling surfaces be increased as much as possible. To promote radiant heat exchange with the graphite, it was assumeo that all interior metal cocling surfaces of the furnace were coated with "Japon" black, which is a compercially available blacking paint that will withstand temperatures as high as these that cain be vithstood by the metal it covers. For the thermal ana!ysis, a constant boundary condition terperature of $25^{\circ} \mathrm{C}$ was assumed for all water-cooled surfaces. The furaace elevator platform that supports the column of graphite elements and pallets was also assumed to have a constant temperature of $25^{\circ} \mathrm{C}$ by virtue of cooling. Heat transfer across the furnace annuli or gaps is expected to be by conduction, convection, and radiation with the shape factors varying from 0.5 to 0.75 . All interior argon gas gaps adjacent to the colum of fuel elemerts and spacers have a total spectral emissivity of 0.8 , and the shape factor was determined for infinitely long concentric cylinders. Gas radiation is not a factor in the transfer of heat inasmuch as argon is not a rerdiating gas. However, the argon must be kept free of mois sure because of the reradiation properties of water vepor as we 11 as the posstbility of a chemical reaction with the giaphite. It was assumed that the volatiles produced during cerbonization would have no reradiation efferts. The net result would be a slight decrease in the efficiency of the furaac:. Radiation in the coolant holes of the fuel elements and pallets was accounted for in the calculated antsotropic conductivity of the graphite.

Heat transfer from the exterior surfaces of the furnace is expected to be by combined natural convection. and radiation to the surrounding atmosphere. An emissivity of 0.6 was assumed for ell external surfaces of the furnace. 


\section{MATERIAL PROPERTIES USED IN THERMAL ANALYSIS}

In a steady-state thermal analysis, the physical property of primary concern is the thermal conductivizy of the waterials involved. The thermal conductivities of the twelve material conditions involved in the furnace analysis are $g$ iven in Tables 1 and 2 . The three materials given in Table 1 are anisotropic. At a given temperature, the thermal corductivity of such a material in the axial direction is different from that in the radial direction. As indicated in Figs. 7, 9, and 10, material number one in iable 1 (HLM graphite) was used as a liner material in the furrace, and the thermai conductivity data given for this material were obtained from prıor investigations..$^{-}$Material 3, Fiberform insulation, was used as a primary insulating material in the furnace, and its thermal conductivities were obtained from manufacturer's data.?

The thermal conductivities of the fuel element composite, material 2 in Table 1, were developed by using formulations set forth in Ref. 4. The conductivities developed and given in Table 1 are based on the use of a fuel block fabricated from unirradiated needle-coke (H-327) graphite as manufacturej by the Great Lakes Carbon Comp.my. The total crosssectional area of the hexagonal graphite prism used for the reference Fort St. Vrain fuel element is $173.93 \mathrm{in}^{2}$ To calculate the thermal conductivities of the reference fuel elements in the furnace, it was estimated that $56.95 \%$ of the total cross-sectional area of an elenent is comprised of graphite, $24.38 \%$ is comprised of fuel holts, ant $18.67 \%$ is comprised oi voids or coolant holes. These coolant holes will be filled with argon gas at atmospheric pressure when the fuel element is being nrocessed in the carbonizing and annealing furnace, and they will be filled with hellum gas under pressure when the element is in the reactor. However, the intended contents of the coolant holes will have little or no effect on the thermal conductivities of the fuel element composite.

The relationstips required to calculate the axial and radial thermal conductivities of the fue 1 element composite as a function of temperature were programmed for the computer. Essentially, these relationships are as follows. The axiol thermal conductivity of tie fuel element was 
Table 1. Thermal Conductivities of Anisotropic Materials Used in Furnace Analysis

\begin{tabular}{|c|c|c|c|c|c|}
\hline \multicolumn{2}{|c|}{ Material } & \multirow{2}{*}{$\begin{array}{c}\text { Temper- } \\
\text { ature } \\
\left({ }^{\circ} \mathrm{F}\right)\end{array}$} & \multicolumn{2}{|c|}{$\begin{array}{l}\text { Conductivity in } \\
\text { Btu/min-in.- }{ }^{\circ} \mathbf{F} \\
\end{array}$} & \multirow{2}{*}{$\begin{array}{l}\text { Ref. } \\
\text { No. }\end{array}$} \\
\hline No. & Name & & Radial & Axial & \\
\hline 1 & $\begin{array}{l}\text { HLM } \\
\text { Graphite }\end{array}$ & $\begin{array}{r}0 \\
500 \\
1000 \\
1500 \\
2000 \\
2500 \\
3000 \\
3500 \\
4000 \\
4500 \\
5000\end{array}$ & $\begin{array}{l}0.08189 \\
0.06250 \\
0.05000 \\
0.04100 \\
0.03430 \\
0.02920 \\
0.02630 \\
0.02390 \\
0.02220 \\
0.02110 \\
0.02060\end{array}$ & $\begin{array}{l}0.11940 \\
0.09780 \\
0.07080 \\
0.05900 \\
0.04860 \\
0.04160 \\
0.03740 \\
0.03400 \\
0.03190 \\
0.03050 \\
0.02960\end{array}$ & 2 \\
\hline 2 & $\begin{array}{l}\text { Fuel } \\
\text { Element }\end{array}$ & $\begin{array}{r}0 \\
200 \\
400 \\
600 \\
800 \\
10 C 0 \\
1200 \\
1400 \\
1600 \\
1800 \\
2000 \\
2200 \\
2400 \\
2600 \\
2800 \\
3000 \\
3200 \\
3400 \\
3600 \\
3800 \\
4000 \\
4200 \\
4400 \\
4600 \\
4800\end{array}$ & $\begin{array}{l}0.04429 \\
0.03857 \\
0.03420 \\
0.03104 \\
0.02893 \\
0.02767 \\
0.02703 \\
0.02678 \\
0.02670 \\
0.02664 \\
0.02653 \\
0.02634 \\
0.02607 \\
0.02573 \\
0.02535 \\
0.02494 \\
0.02448 \\
0.02400 \\
0.02348 \\
0.02292 \\
0.02233 \\
0.02170 \\
0.02105 \\
0.02040 \\
0.01979\end{array}$ & $\begin{array}{l}0.10770 \\
0.09167 \\
0.07859 \\
0.06798 \\
0.05942 \\
0.05255 \\
0.04705 \\
0.04267 \\
0.03919 \\
0.0364 ? \\
0.03423 \\
0.03250 \\
0.03116 \\
0.03013 \\
0.02938 \\
0.02888 \\
0.02861 \\
0.02656 \\
0.02871 \\
0.02905 \\
0.02956 \\
0.02,20 \\
0.03094 \\
0.03168 \\
0.03236\end{array}$ & $\begin{array}{l}4 \\
\& \\
5\end{array}$ \\
\hline 3 & $\begin{array}{l}\text { Fiberform } \\
\text { Insulation }\end{array}$ & $\begin{array}{r}0 \\
800 \\
1300 \\
1700 \\
2000 \\
2500 \\
3000 \\
3500 \\
4000\end{array}$ & $\begin{array}{ll}3.472 & E-5 \\
6.944 & E-5 \\
8.681 & E-5 \\
i .157 & E-4 \\
1.505 & E-4 \\
2.315 & E-4 \\
2.697 & E-4 \\
3.669 & E-4 \\
5.208 & E-4\end{array}$ & 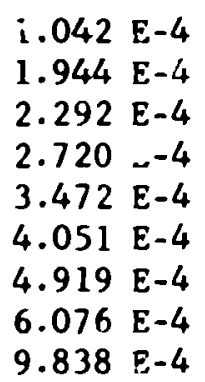 & 3 \\
\hline
\end{tabular}


Table 2. Thermal Conductivity of Isotropic Materials Used in Furnace Analysis

\begin{tabular}{|c|c|c|c|c|}
\hline \multicolumn{2}{|c|}{ Material } & \multirow{2}{*}{$\begin{array}{c}\text { Temper- } \\
\text { ature } \\
\left({ }^{\circ} \mathrm{F}\right)\end{array}$} & \multirow{2}{*}{$\begin{array}{c}\text { Conductivity } \\
\left(\text { Btu/min-in. }{ }^{\circ} \mathrm{F}\right)\end{array}$} & \multirow{2}{*}{$\begin{array}{l}\text { Ref. } \\
\text { No. }\end{array}$} \\
\hline No. & Name & & & \\
\hline 5 & Fiberfrax - H & $\begin{array}{r}0 \\
500 \\
1000 \\
1500 \\
2500 \\
2500 \\
3000 \\
3500\end{array}$ & $\begin{array}{l}0.00002315 \\
0.00004630 \\
0.00009028 \\
0.00014470 \\
0.00021060 \\
0.00030210 \\
0.00036460 \\
0.00043400\end{array}$ & 6 \\
\hline 6 & $\begin{array}{l}\text { Modifled } \\
\text { Stainless } \\
\text { Steel }\end{array}$ & $\begin{array}{r}0 \\
1000 \\
1800\end{array}$ & $\begin{array}{l}0.001260 \\
0.001420 \\
0.001530\end{array}$ & \\
\hline 7 & Argon & $\begin{array}{r}0 \\
400 \\
800 \\
1200 \\
1600 \\
2000 \\
2400 \\
2800 \\
3200 \\
3600 \\
4000 \\
4400 \\
4800 \\
5200\end{array}$ & $\begin{array}{l}0.00001250 \\
0.00002000 \\
0.00002640 \\
0.00003330 \\
0.00003820 \\
0.00004170 \\
0.00004510 \\
0.0000486 C \\
0.00005130 \\
0.00065550 \\
0.00005830 \\
0.00006250 \\
0.00006520 \\
0.00006670\end{array}$ & 9 \\
\hline 9 & $\begin{array}{l}\text { Strip } \\
\text { Heaters }\end{array}$ & 0 & 0.3330 & \\
\hline 11 & $\begin{array}{l}\text { Electrode } \\
\text { Grade } \\
\text { Graphite }\end{array}$ & $\begin{array}{r}0 \\
200 \\
400 \\
600 \\
800 \\
1000 \\
1200 \\
1400 \\
1600 \\
1800 \\
2260 \\
2800 \\
3200 \\
3632 \\
4532 \\
5432\end{array}$ & $\begin{array}{l}0.10560 \\
0.09310 \\
0.08 ; 30 \\
0.07500 \\
0.06810 \\
0.06110 \\
0.05560 \\
0.05000 \\
0.04610 \\
0.0 \$ 310 \\
0.03860 \\
0.03470 \\
0.03190 \\
0.03010 \\
0.02780 \\
0.02640\end{array}$ & 7 \\
\hline
\end{tabular}


Table 2 (continued)

\begin{tabular}{|c|c|c|c|c|}
\hline \multicolumn{2}{|c|}{ Material } & \multirow{2}{*}{$\begin{array}{c}\text { Temper- } \\
\text { atur? } \\
(\because \%)\end{array}$} & \multirow{2}{*}{$\begin{array}{c}\text { Conductivity } \\
\left(\text { Ptu/min·in. }{ }^{-} \text {F }\right)\end{array}$} & \multirow{2}{*}{$\begin{array}{l}\text { Ref. } \\
\text { No. }\end{array}$} \\
\hline No. & Name & & & \\
\hline 12 & $\begin{array}{l}\text { Type } 304 \\
\text { Stainless } \\
\text { Steel }\end{array}$ & $\begin{array}{r}0 \\
1000 \\
i 900\end{array}$ & $\begin{array}{l}0.01260 \\
0.01420 \\
0.01530\end{array}$ & 8 \\
\hline 14 & $\begin{array}{l}\text { Po:ous } \\
\text { Carbon }\end{array}$ & $\begin{array}{r}0 \\
5000\end{array}$ & $\begin{array}{l}0.001290 \\
0.007640\end{array}$ & 7 \\
\hline 17 & Argon-3 & $\begin{array}{r}0 \\
500 \\
1000 \\
1500 \\
2000 \\
2500 \\
3000 \\
3500\end{array}$ & $\begin{array}{l}0.00010400 \\
0.00007180 \\
0.00006270 \\
0.00006040 \\
0.00006580 \\
0.00007430 \\
0.00008330 \\
0.00009030\end{array}$ & $\begin{array}{c}9 \\
\& \\
10\end{array}$ \\
\hline 18 & Argon-4 & $\begin{array}{r}0 \\
500 \\
1000 \\
1500 \\
2000 \\
2500 \\
3000 \\
3500\end{array}$ & $\begin{array}{l}0.00012300 \\
0.00008790 \\
0.00007160 \\
0.00006900 \\
0.00006780 \\
0.00007430 \\
0.00008330 \\
0.00009030\end{array}$ & $\begin{array}{c}9 \\
\& \\
10\end{array}$ \\
\hline
\end{tabular}

calculated by using the following equation."

$$
\mathrm{K}_{\mathbf{a}}=\mathrm{Ak_{ \textrm {g } }}+\mathrm{Bk_{ \mathbf {f } }}+\mathrm{C \mathbf {k } _ { \mathbf { r } }} \text {, }
$$

where

$K_{a}=$ the axial thermal conductivity of the fuel element composite as a function of temperature, Btu/hr-ft. ${ }^{\circ} \mathrm{F}$,

$A=$ ratio of cross-sectional area of grapitite (G) in in. ${ }^{2}$ to total cross-sectional area of fuel element compesite $(Z ;=G / Z$

$=99.053 / 173.93=0.5695$,

$k_{g}=$ the axial thermal conductivity as a function nf temperature of the particular graphite used in the fuel element, Btu/hr.ft. $\mathrm{F}$,

$B=$ ratio of cross-sectional area of fuel holes (F) in in. ${ }^{2}$ to total cross-sectional area of fuel element composite $(Z)=F / 7$

$=42.404 / 173.93=0.2438$, 
$k_{f}=$ thermal conductivity of the fuel rods

a a constant $3.0 \mathrm{Btu} / \mathrm{hr} \cdot \mathrm{ft} \cdot{ }^{\circ} \mathrm{F}$,

$C=$ ratio of cross-sectional area of coolant holes ( $V$ ) in in. ${ }^{2}$ to total cross-sectional area of fuel element composite $(Z)=v / Z$ $=32.473 / 173.93=0.1967$, and

$k_{r}=$ net equivalent thermal conductivity resulting fron radiation across the coolant holes, Btu/hr.ft. ${ }^{\circ} \mathrm{F}$.

The axial thermal conductivities as a function of temperature $\left(k_{g}\right)$ used in Eq. 6.1 for the $\mathrm{B}-327$ graphite were those reported by Frice ${ }^{5}$ for the unirradiated matezial. The net equivalent thermal conductivity resulting from radiation across the coclant holes in the referer:e fue 1 element is given by the following eçution.4

$$
k_{r}=\left(0.444 \times 10^{8}\right) \sigma \epsilon d \pi^{3} \text {, }
$$

where

$$
\begin{aligned}
\sigma & =\text { Stefan-Boltzmann constant } \\
& =0.171 \times 10^{-9} \mathrm{Btu} / \mathrm{hr} \cdot \mathrm{ft}^{2} \cdot{ }^{\circ} \mathrm{R}^{4}, \\
\epsilon & =\text { emissivity of granhite }=0.8, \\
\mathrm{~d} & =\text { diameter of coolant hole }=0.625 \mathrm{in} \cdot, \text { and } \\
T & =\mathrm{T}_{\mathbf{R}} / 1000 \\
& \text { where } \mathrm{T}_{\mathbf{R}}=\text { mean temperature of fuel element, }{ }^{\circ} \mathrm{R} .
\end{aligned}
$$

The algorithm used to calculate the radial thermal conductivity $\left(K_{r}\right)$ of the composite fuel element in $B t i / h r \cdot f t \cdot{ }^{\circ} \mathrm{F}$ is as follows. 4

$$
k_{T}=\left(C_{1} k_{g}\right) \frac{1+C_{2} T / k_{g}\left[\left(C_{4}+k_{g} / k_{f}\right) /\left(C_{g}+k_{g} / k_{f}\right)\right]}{1+C_{3} T / k_{g}\left[\left(C_{5}+k_{g} / k_{f}\right) /\left(C_{g}+k_{g} / k_{f}\right)\right]}
$$

where

$$
\begin{aligned}
k_{\mathbf{B}}= & \text { radial theral conductivity as a function of termerature } \\
& \text { of the particular graphite used in the fuel element compos- } \\
& \text { ite, Btu/hr} \cdot \mathrm{ft} \cdot{ }^{\circ} \mathrm{F}, \\
\mathrm{T}= & \mathrm{T}_{\mathrm{R}} / 1000, \\
\mathrm{k}_{\mathrm{f}}= & \text { thermal conductivity of fuel rods }=\text { a constant } \\
= & 3.0 \mathrm{Btu} / \mathrm{hr} \cdot \mathrm{ft} \cdot{ }^{\circ} \mathrm{F} \text {, and } \\
\mathrm{C}_{1}-\mathrm{C}_{\mathbf{B}}= & \text { consta: } \cdot \text { s wose values are defined as } \\
\mathrm{C}_{1}= & 0.360,
\end{aligned}
$$




$$
\begin{aligned}
& c_{2}=0.523, \\
& c_{3}=2.500, \\
& c_{4}=4.100, \\
& c_{5}=1.200, \text { and } \\
& c_{8}=8.700 .
\end{aligned}
$$

The axial and radial thermal conductivities and specific heat of wiererce fuel elements fabricated from unirradiated H-327 graphite were computed as a function of temperature, and the resulting output for temperaturis from zero to $5000^{\circ} \mathrm{F}$ are given in Table $\mathrm{C} .1$ of Appendix $\mathrm{C}$. The cumputed condictivity data are illustrated as a funition of tomperature in Fig. C.l (Appendix C). The thermal conductivities and speciflc hoats were als: computed for réerence fuel elemenis fabricated from unirradiated $\mathrm{H}-451$ graphite. The restiting output is given in Table C.2 of Appendix $C$, and the thermal conductivity data are illustrated in Fig. C. 2 .

The remaining nine materiols or material conditions involved in the steady-state analysis of the furnace thermal design are not anisocropic, and the thermal conductivities for these materiais are given in Table 2. The area between the strip heaters (material 9) was filled with FiberfraxH Felt (material 5), which is a ceramic fiber insulation whose the rmal corductivity data were supplied by the manufacturer. ${ }^{B}$ The strip heaters were given relatively high conductivities to curtail internal gradients. Electrode-grade graphite (material 11) was used as the material of construction for the graphite heaters in the intermediate- and high-temperature heating zones of the furrdce, and the thermal conductivities of this material as a finction of temperature were also obtained from manufacturer's data. ${ }^{7}$ The thermal conductiofty data for type 30 stainless steel (material 12) used in the analysis were reported by Kim. ${ }^{9}$ Those data were modified in some locations (material 6) to permit an increase in nodal spicing and enhance computer running time. For these reasons, strip heater meteral (material 9) was substituted for the thin stainless steel strip connecting the hot interior of the furnace with the watercooled wall and uses as an insulation tnterface, thereby increasing the material thichisss by a factcr of four and reducing the condustutey by a factor of four. 
The thermal conductivities of the argon gas in the main channel of the furnace (material 7) used in the analysis were reported in a National Bureau of Standards Circuiar. ${ }^{9}$ Argon-3 (material 17) and argon-4 (material 18) were defined to account for enhanced thermal conductivity resulting from natural convection in cylindrical annulus filled with stagnant gas. This enhanced conductivity is a function of the Raleigh number and the length-to-diameter ratios of the annuli, 10 and materials 17 and 18 the used in the anaiysis te depict different $L / D$ ratios. No allowance ras made for nztural corvection in the main channel of the furnace inasmuch as the system was designed to curtall this phenomenon. Convection in the interior channels of the fuel elements was accounted for in computing the anisotronir conductivities of the fuel slement composite. 
?. EESULTS OF THERML ANALYSIS, CONCLUSIONS, AND RECORENDATIONS

The HEATING4 program was run on the IBM $360 / 91$ computer at ORNL to perform the thermal analysis of the furnace design described herei-

Like any other generai heat transfer computer program, the HEATING4 program calls for the heat source distribution to be specified by the user. Therefore, the initial task of the analysis was performance of a lengthy trial-and-error process by which the power distribution for the heaters was estimated and the resulting temperatures were compared with the desired axial cemperature profile in the furnace. This process was difficult and time consuming because of the complex interaction between the various zones of the furnace. The best distribucion of heat sources (heaters) and sinics (cooling water) that could be obtained with a reasonable effort was used for the final temperacure distribution analysis. The power input for the top-loaded furnace configuration totaled $101.44 \mathrm{kH}$. Ahout $2.28 \mathrm{kH}$ were supplled to the strip heaters in the furnace low-temperature heating zone in amounts that varied from 286 watts in the last heater co zero watts in the first heater at the top of the furnace processing chamber. The charging valve at the tof of the chamber was supplied with 325 watts of power. The pover if lut to the graphite heaters in the intermediate- and high-temperature heating zones of the furnace totaled $98.83 \mathrm{kH}$. The distribution of power to the regions in these portions of the furnace was $23.12 \mathrm{~kW}$ to graphite ineater region 1 , $17.82 \mathrm{~kW}$ to region $2,12.86 \mathrm{~kW}$ to region $3,14.34 \mathrm{~kW}$ to region $4,7.87 \mathrm{~kW}$ to region $5,12.83 \mathrm{~kW}$ to region 6 , and $9.99 \mathrm{~kW}$ to region 7 .

The power input used for the bottom-loaded configuration was $96.6 \mathrm{~kW}$. No power was input to the charging valve or the strip heaters, and that input for the graphite heatcr regions was the same as for the top-loaded configiration except for region 7. In the hottomm loaded configuration, the power input to graphite heater region 7 was reduced to $8.34 \mathrm{~kW}$. Computer runs were madc using these power distributions, the furnace boundary conditions discussed in Section 5 , the internal heat genaration simulating the energy transport resulting from mass movement discussed in Section 4, and the materials and their conductivities given in section 6 . The 
computed temperative profile is comared with the desired profile for the top-loaded furnace configuration in Fig. 12 and for the bottom-loaded configuration In F18. 13.

As a result if the thermal analysis described hereft; it ras concluded that the furnace destign has the pocential capability of meeting the destred thermal criteria. With respect to the power requirements of the furnace, the results of the computer analysis agree closely with those of the simple mass t-ansfer calculations. Hovever, those results are only as rellable as the thermal transport data used, and the accuracy tolerance assumed for those data was plus or minus 10 to $15 \%$.

The results of the steady-state anglysis indicate that the axial temperature profile in the furnace is quite sensitive to both the input and distribution of power to the heaters, piiiticularly the strip heaters in the upper portion of the furnace processing chamber. It was concluded that the desired temperacure profils can be obtained by further refinement of the power supply and distribution to the strip heaters. Further, the data 11 lustrated In Figs. 14 and 15 indicate that temperature profiles that are both higher and lower than the desired proille can be obtained by varying the type and thickness of the insslation used in connection with the strip heaters in the upper portion of the furnact. This capability will afford a means of adjusting the temperature profile if the thernophysical properties of the furnace were either overestimated or underestimated.

It should be noted that the analysis reported herein was bascd on a continuous steady-state simulation. In reality, there will be a pause of alout $10 \mathrm{~m}$ nutes at the end of every 90-minute cycle for unloading and lciading procedures and a new fuel element and pallet will be introduced into the furnace, resulting in the discurbance of any equilibrium that may hive been achieved. Therefore, it is recoumended that transient therma! analyses of the furnace design be performe't to verify the results obcained from the steady-state analysis described herein. Transient anal.. yses could also be performed to determine the control limications necessary for safe operation of the furnacu by changing the boundary conditions to simulate mechanical fallure, loss-of-cooling, and loss-of-power conditions. 


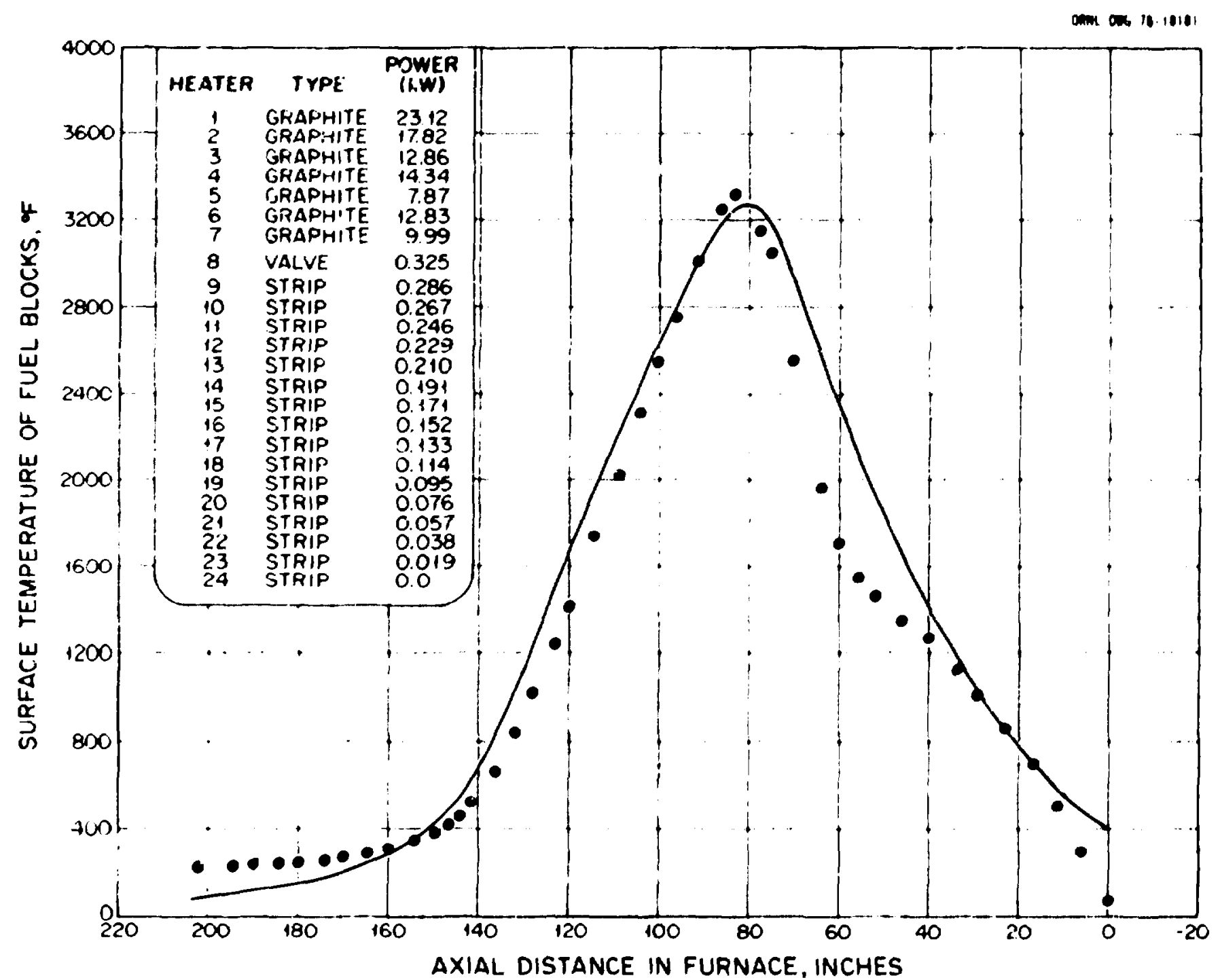

Fig. 12. Results of Computer Analysis of Furnace Design Compared with Desired Temperature Proftle for Top-Loaded Configuration. 


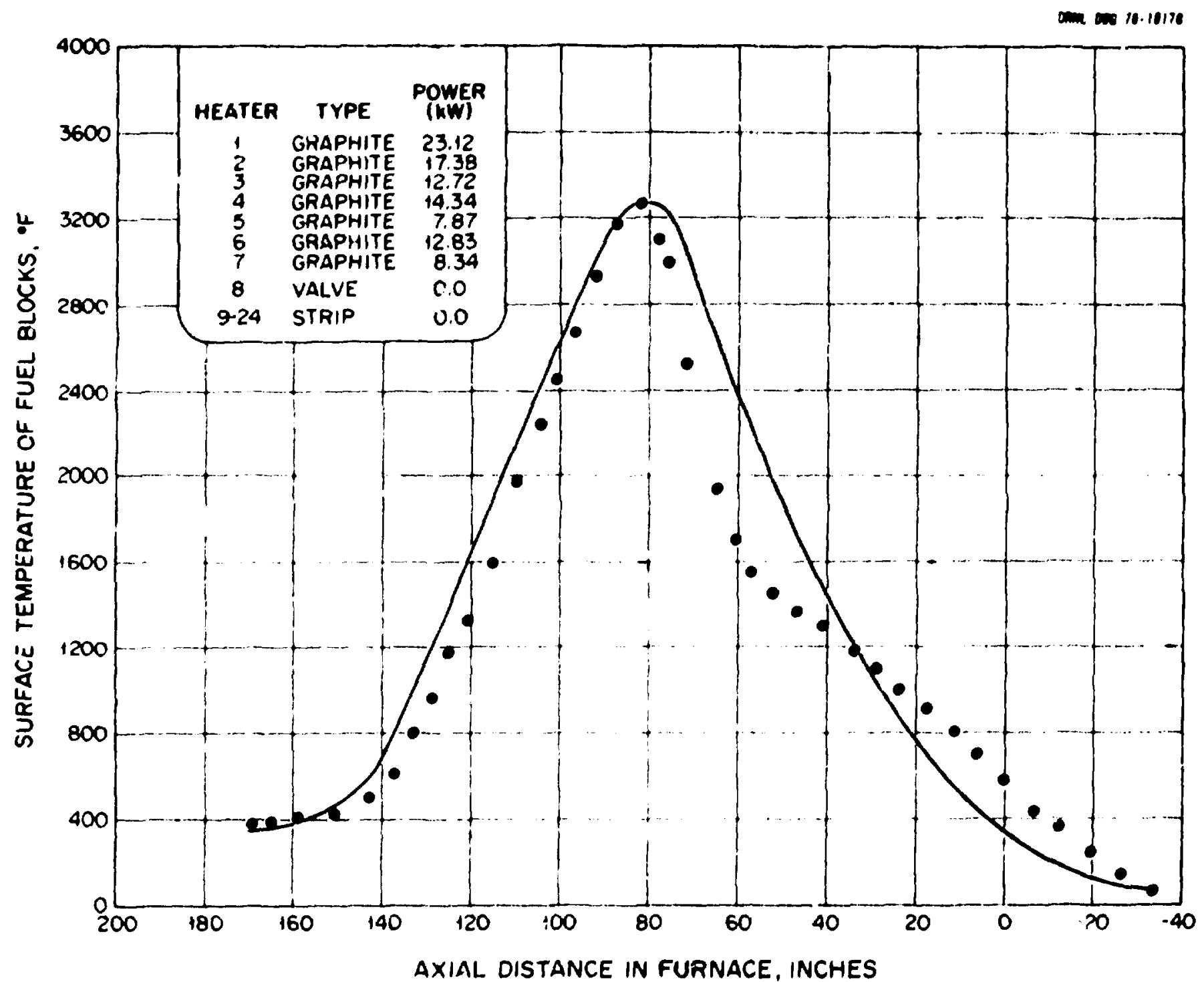

Flg. 13. Results of Computer Analysig of Furnace Design Cumpared With Desired Temperature Profile for Bottom-Loaded Conflguration. 
$\sin 000010.1017$

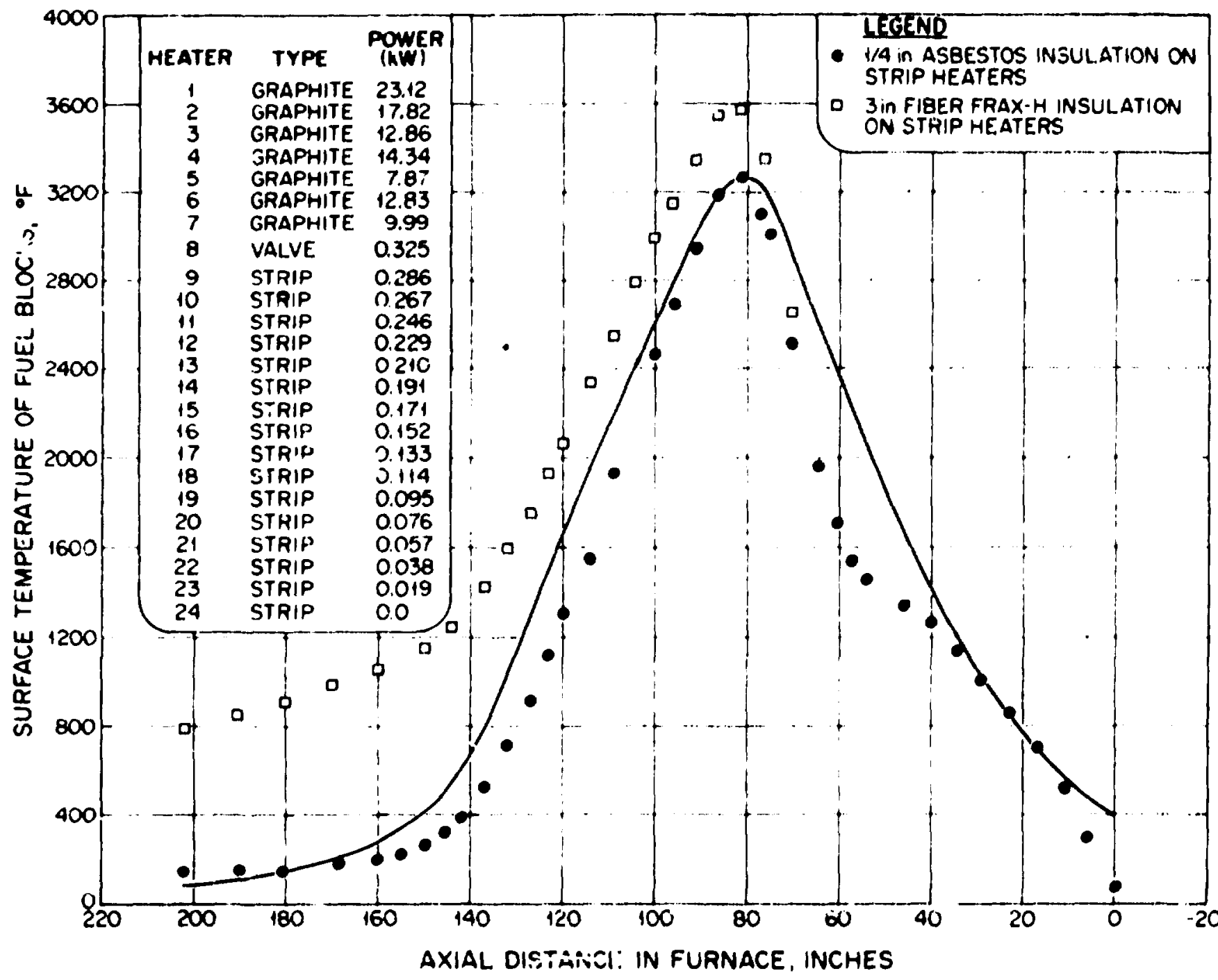

Fig. 14. Regults of Computer Analyses Obtalned By Varylng Insulation in Upper Portion of Furnace Comparet With Desired Temperature Proftle for Top-Loaded Configuration. 
$\operatorname{anc} 100010.10110$

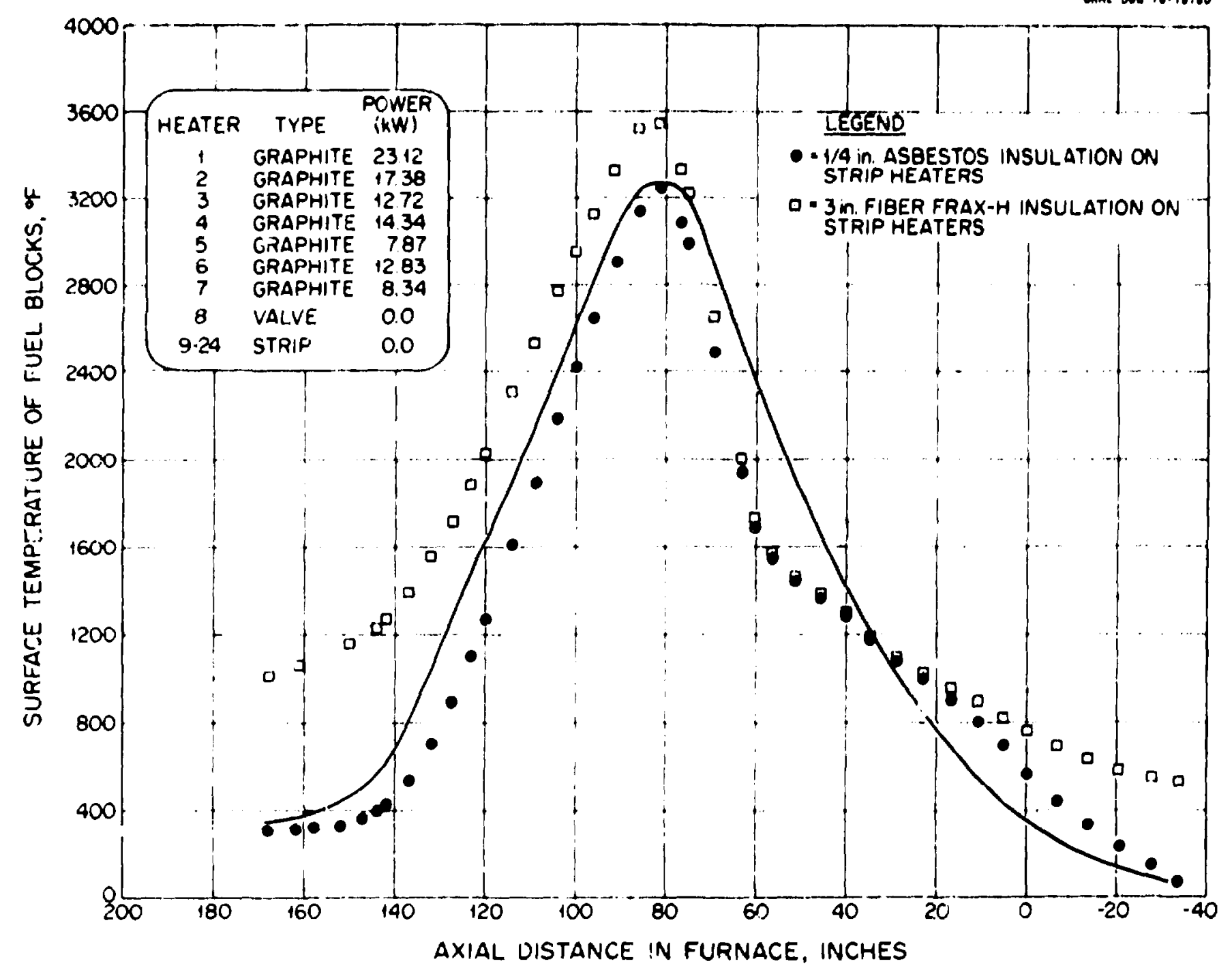

F18. 15. Results of Cumputer Allalyses Obtalned By Varying Ingulation in Upper. Pnrtion of Furnace Compared With Desired Temperature Profile for Bottom-Loaded Configuration. 
REFERENCES

1. W. D. Turner and M. Siman-Tov, "HEATING3-- An IBM 366 Heat Conưuction Program," USAEC Report ORYL TM-3208, Oak Ridge National Laboratory, Oak Ridge, Tennessee, February 1971.

2. W. P. Eatherly, Metals arj Ceramics Division, Oak Ridge National Laboratory, personal communication to G. F. Llewellyn, Oak Pidge Nationa" aboratory.

3. "Product Data," Fiber Materials, Inc., Biadeford Industrial Park, Bidde ford, Maine 04005 .

4. Put lic Service Company of Colorado, page 39 in Section 3 of "Preliminary Safety Analysis Report for the Fort St. Vrain Reactor (Docket Number 50-267)."

5. R. J. Price, "Thermal Conductivity of Neutron-Irradiated Reactor Graphites," Report GA-Ai3157, General Atomic Company, San Diego, California 92138, October 8, 1974 .

6. "Product Specifications," The Carborundum Compary, Refractories and Electronics Division, Ceramic Fiber Plant, Niagara Falls, New York.

7. "Carbon Products Pocke: Handbook," Union Carbi Je Corporation, Carbon Products Division, New York, New York.

8. Choong S. Kim, "Thermophysical Froperties of Stainless Steels," Report ANL-75-55, Argonne National Laboratory, Argonne, Illinois, September 1975.

9. Joseph Milsenrati et al., Tables of Thermal Properties of Gases, National Bureau of Standards Circular 564, U.S. Guve ament Printing Office, Wrishington, D. C., November 1, 19j5, Tatie 3-9, i- 129.

1C. E. R. G Eckert and R. M. Drake, Jr., Heat and Mass Transfer, McGraw-ril 11 Book Company, Inc., New York, New York, 1959, P. 328. 


\section{APPENDICES}


45

Appendix A

MASS-FLON STALLION DATA

FOR FUEL ELEMENTS FABRICATED PROM H-327 GRAPHITE 


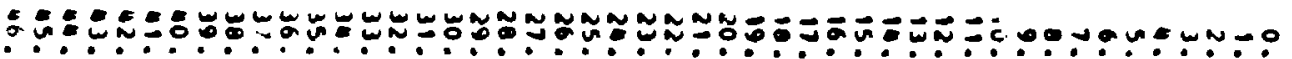

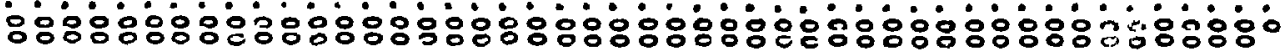

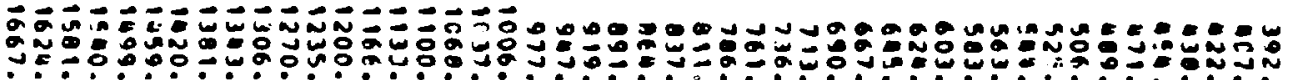

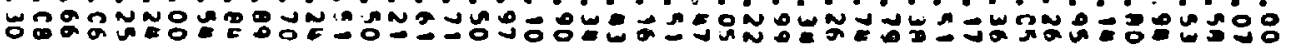

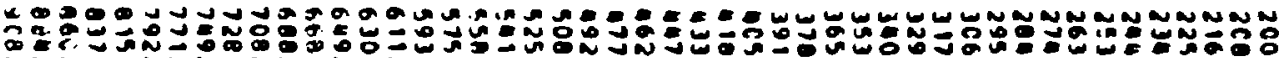

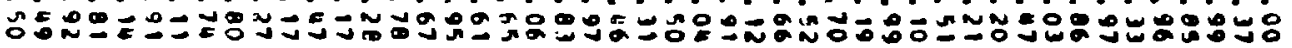

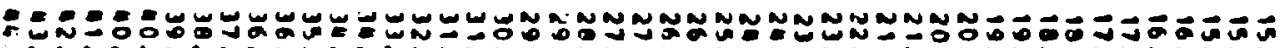

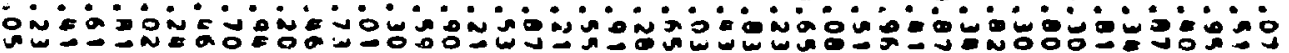

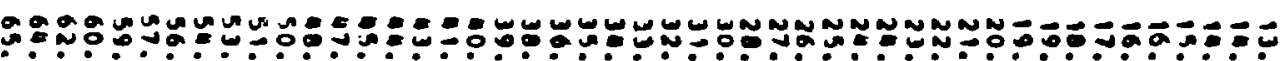
o jus

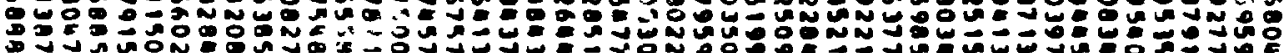

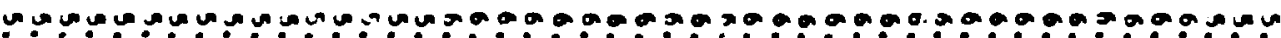
Fon

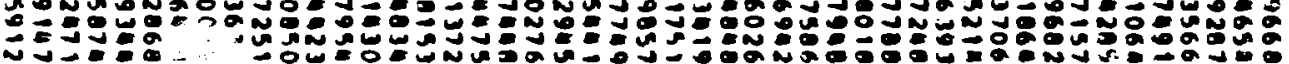

-

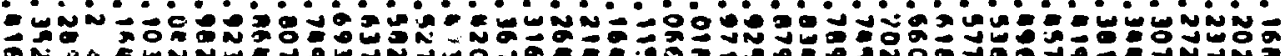

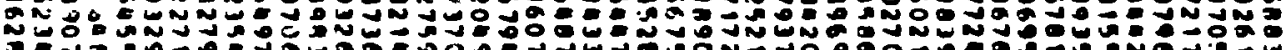

$000000000000000 \mathrm{C}=300000000000000000000000000000$

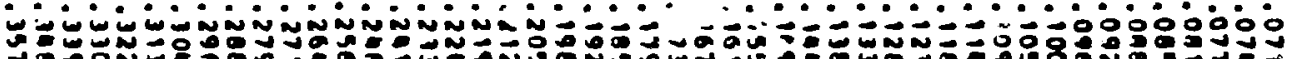

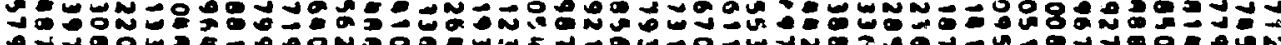

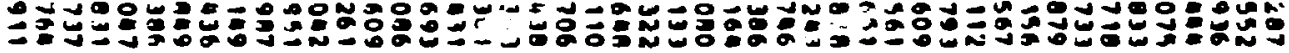

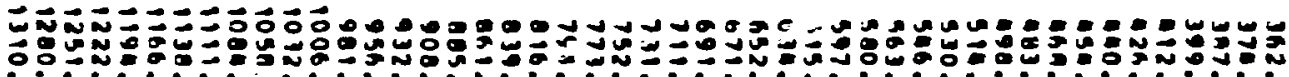

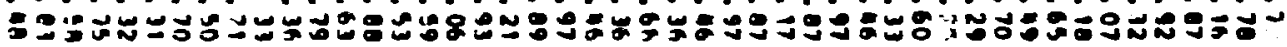

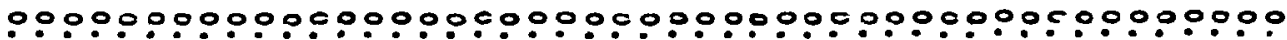

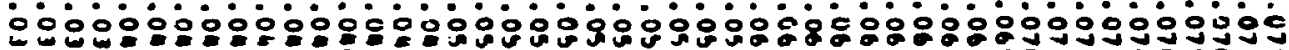

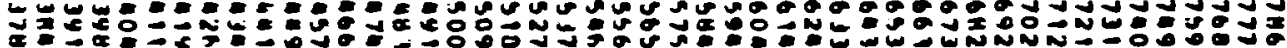

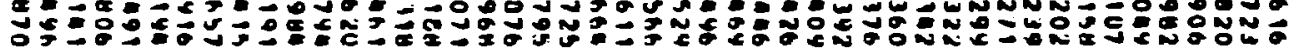

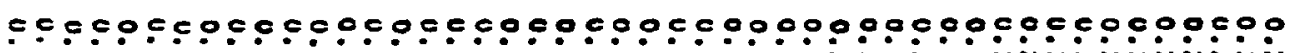

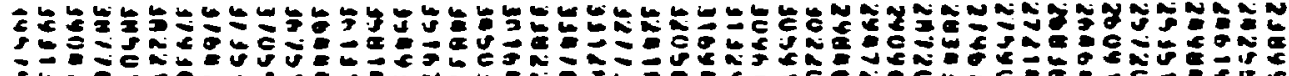

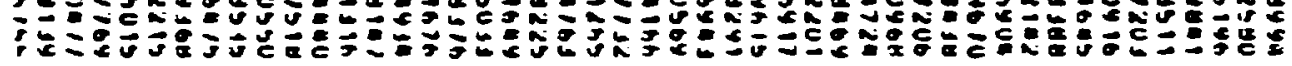




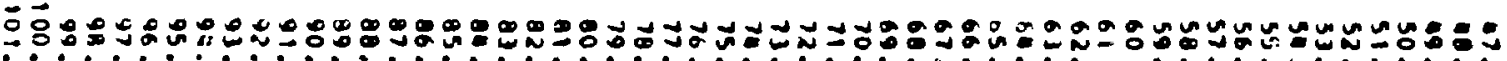

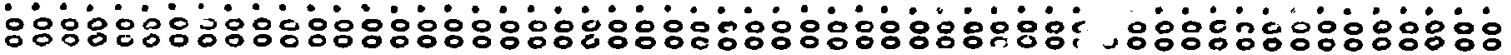

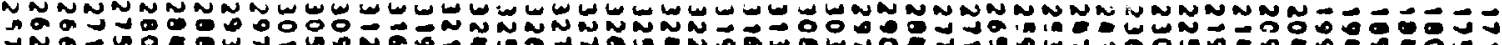

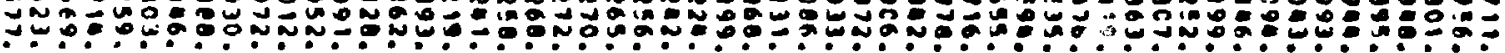

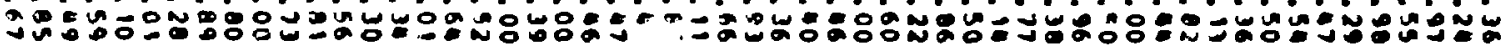

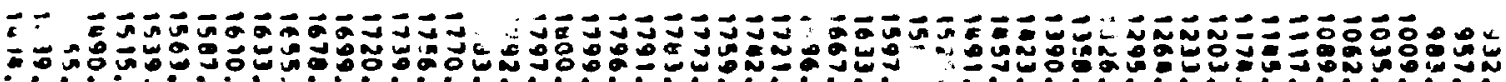

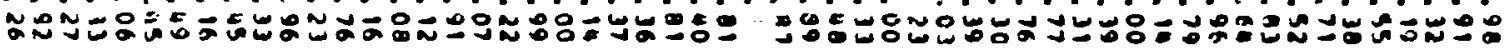

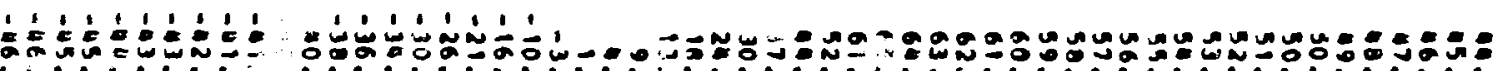

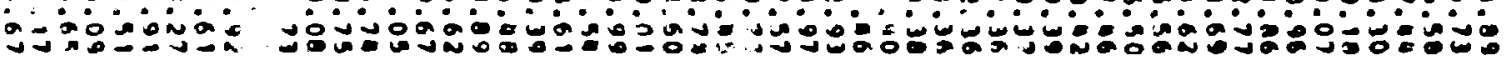

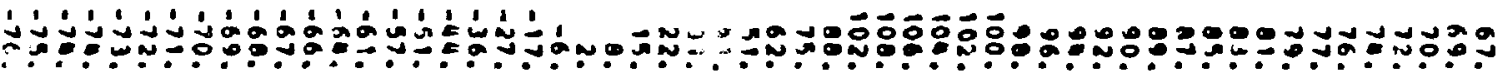
on 0 웅

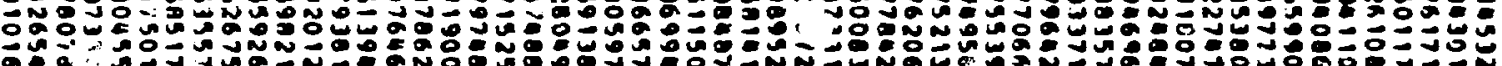

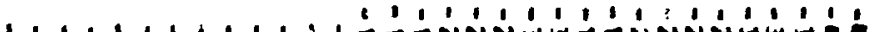

"

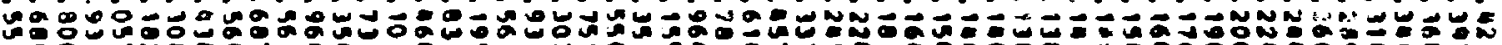

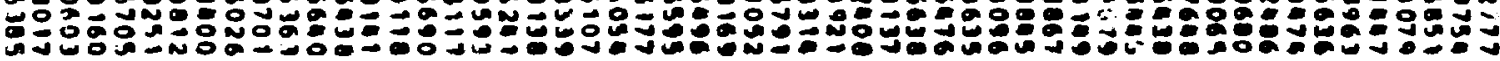

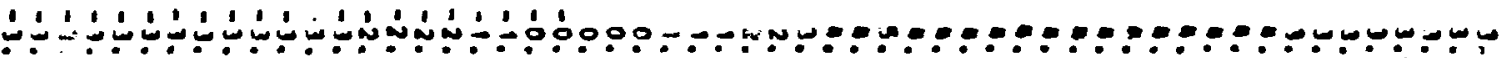

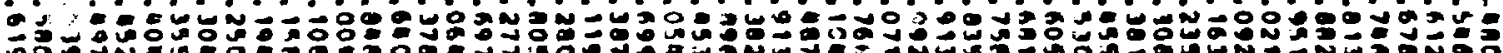

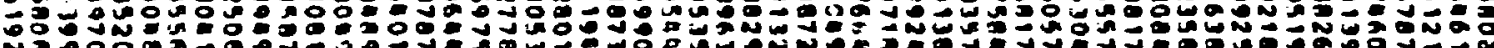

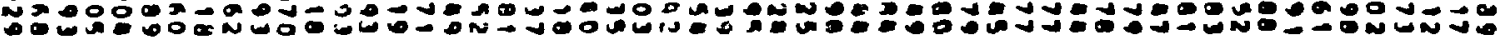

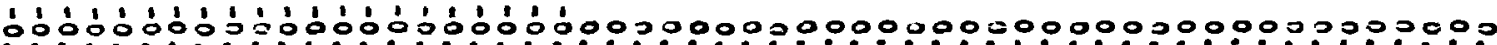

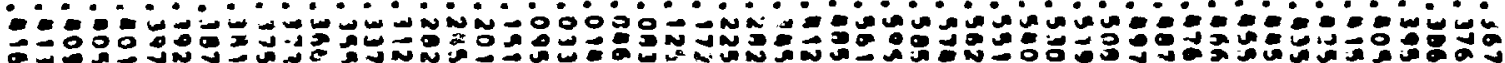

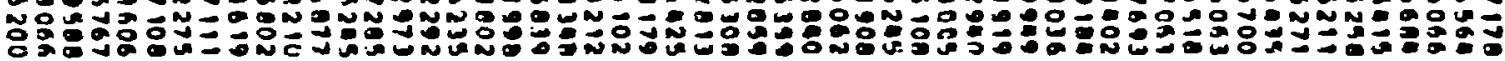

$1,1,1,1,1,1,1,1,1$

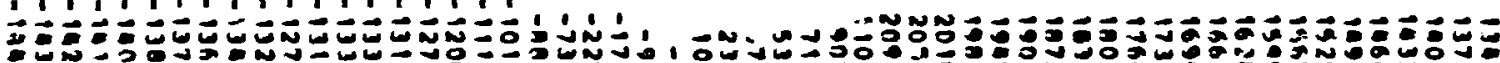

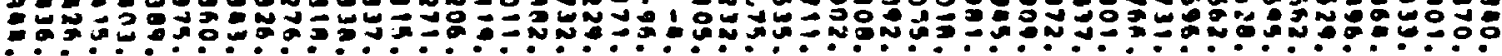

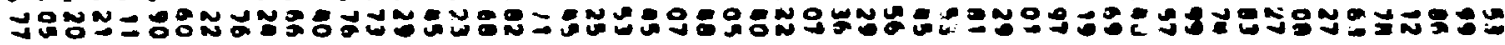

0000000000000000000000000000000000000000000000000000000

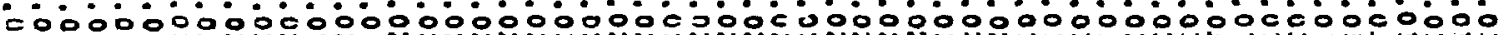

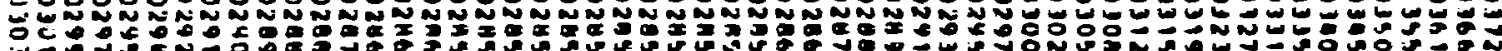

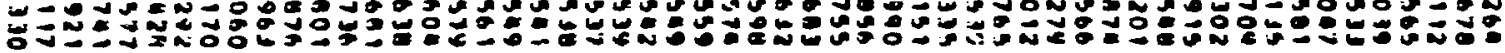

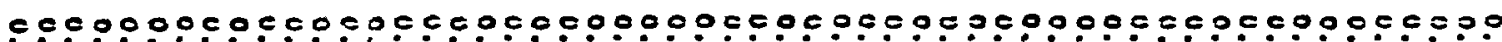
Z6

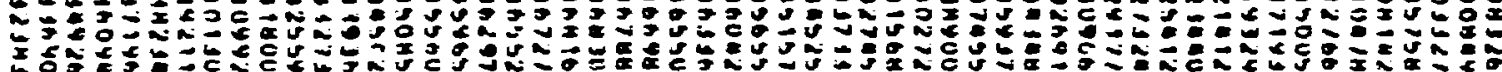




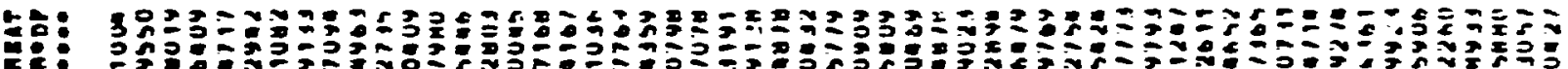
순

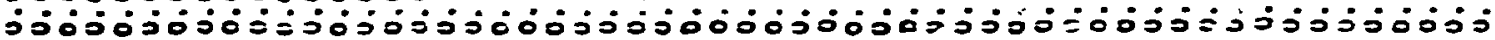

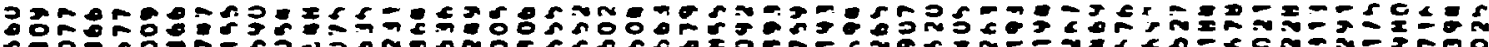

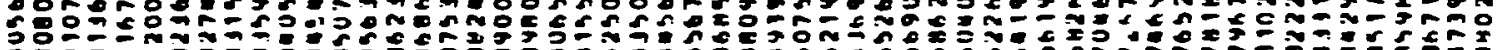

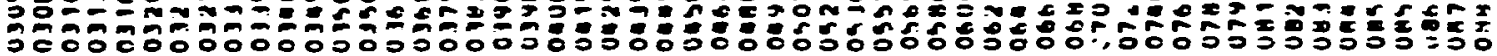

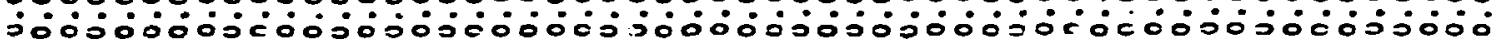

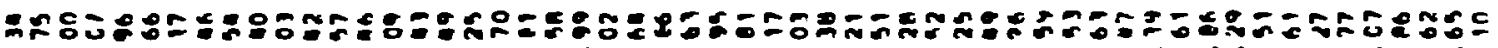

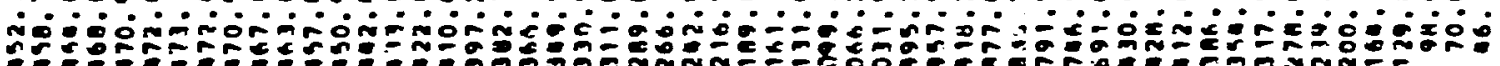

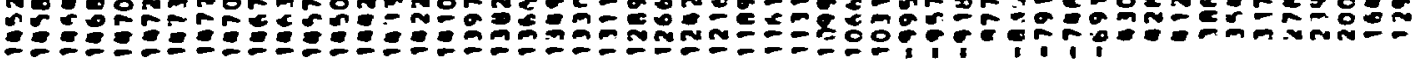

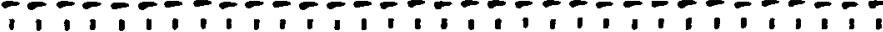

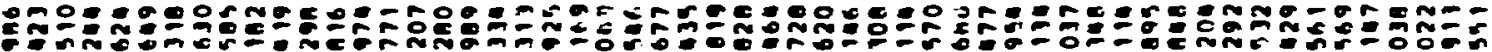

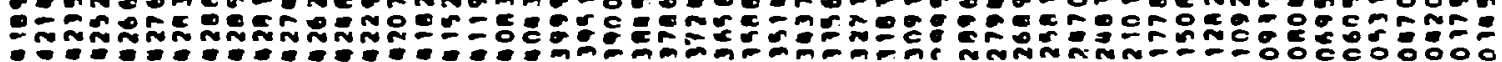

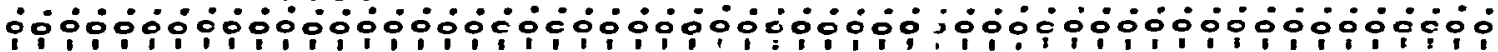

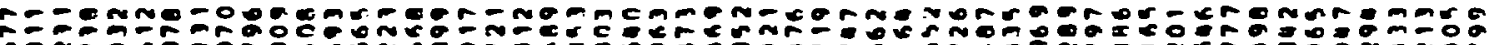

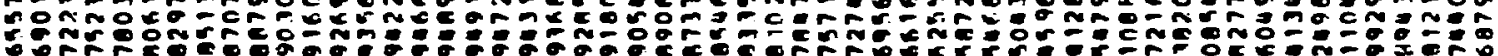

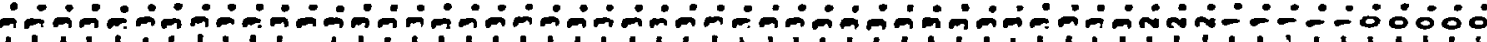

$\because=:$

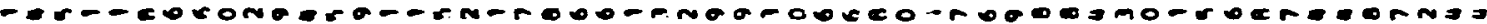

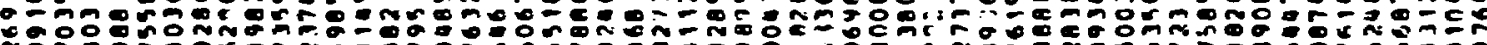

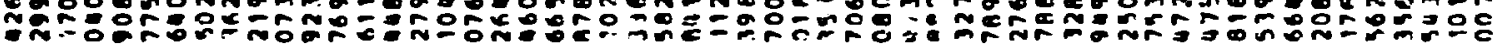

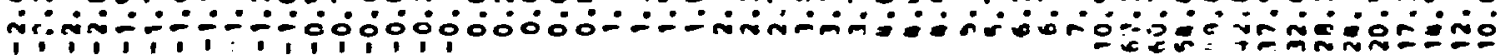

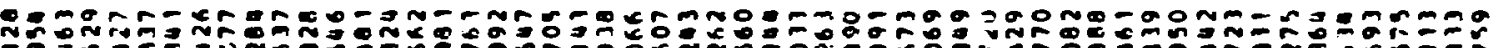

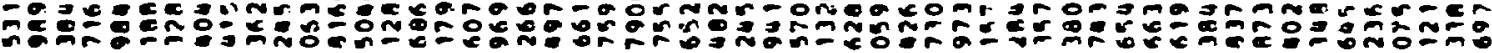

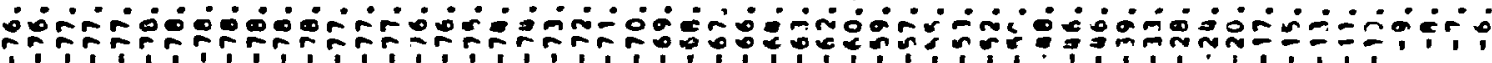

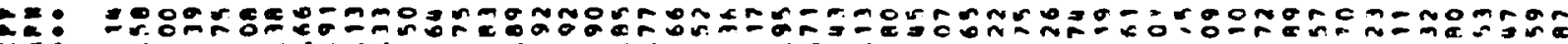

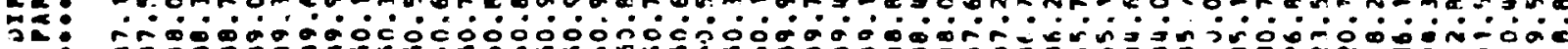
an :

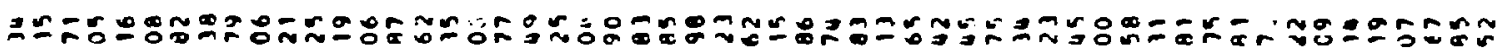

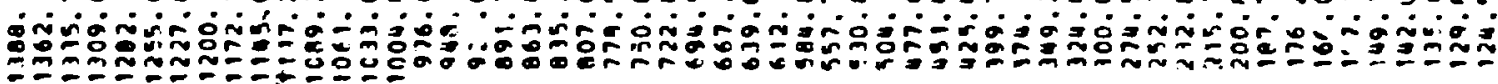

急:

aㄹ.

定:

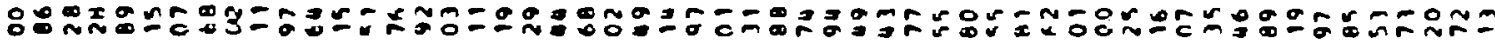

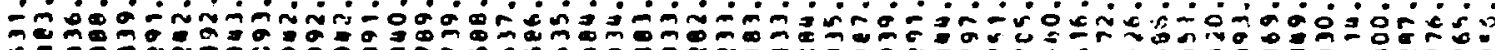

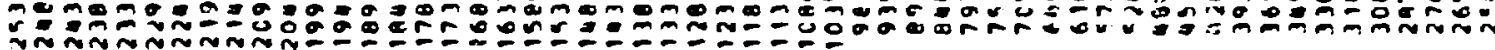

:

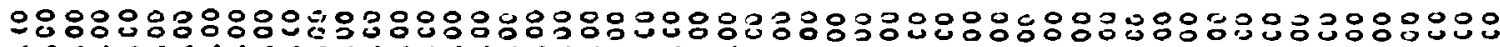

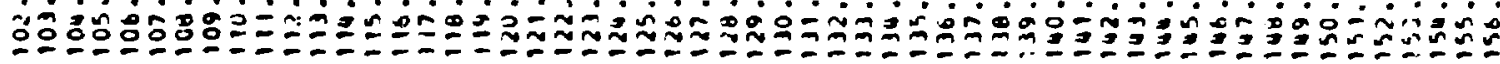


Table A.i (continued)

\begin{tabular}{|c|c|c|c|c|c|c|c|}
\hline 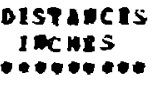 & 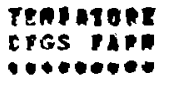 & $\begin{array}{l}\text { TERPATOAE } \\
\text { DEGS CENT } \\
\text { WOOHOE }\end{array}$ & 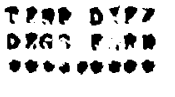 & 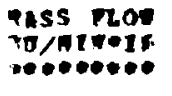 & 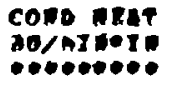 & 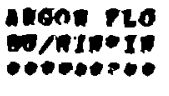 & 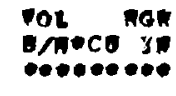 \\
\hline 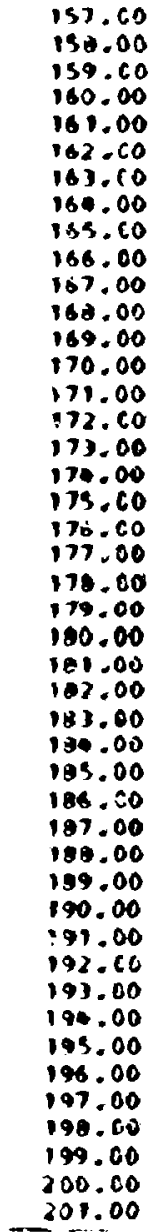 & 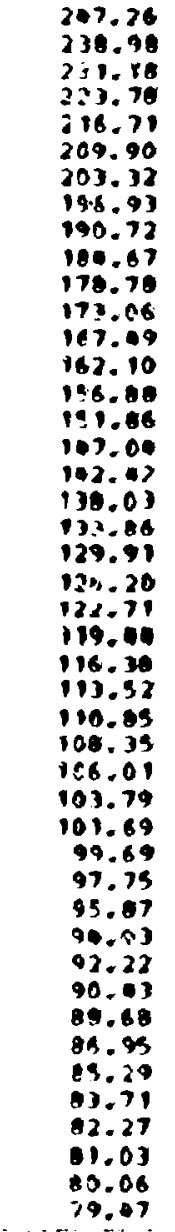 & 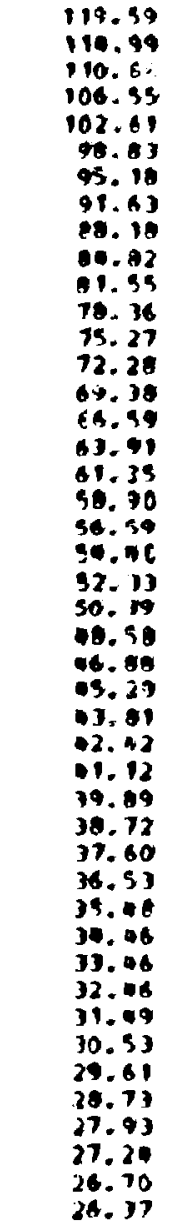 & 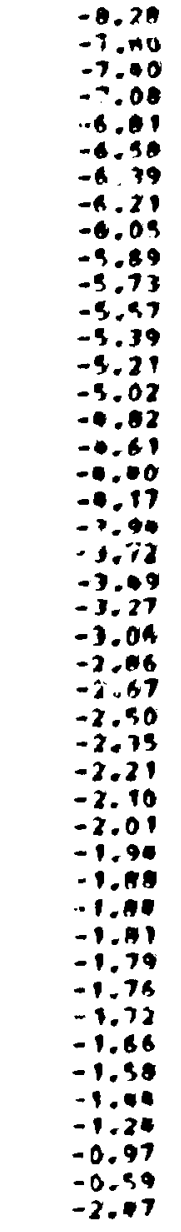 & 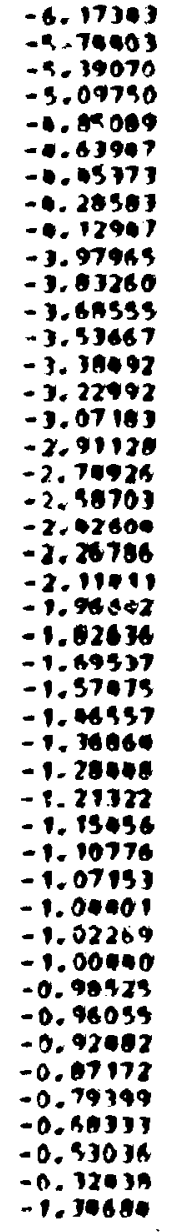 & 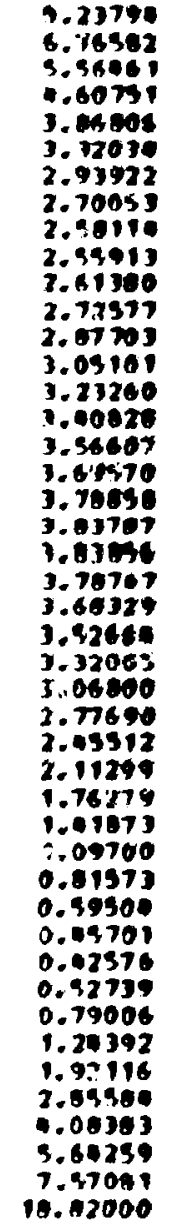 & 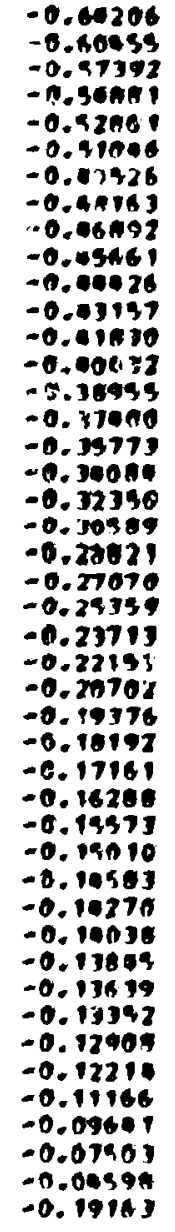 & 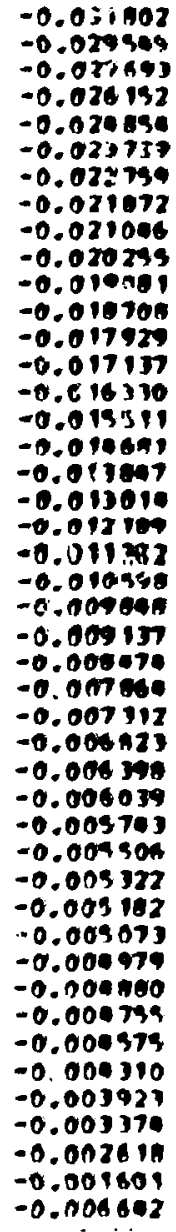 \\
\hline
\end{tabular}

TnTal ron The cono

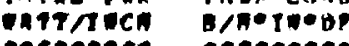

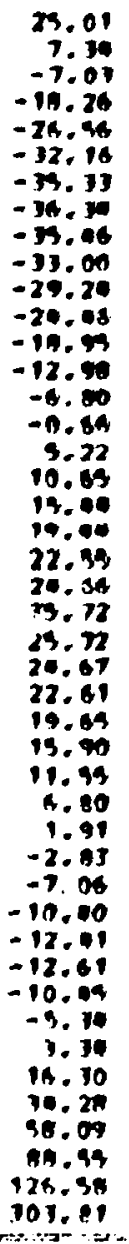

$\mathrm{i} .000 \mathrm{0}: 10$ 8009175 0.30970 0.090712 0.04169 0.091699 0.09116 0.091002 0.093031 .093es? 0.09620 0.09560 0.099046 0.005020 0.0957170 0.096124 $0.09405 x$ 0.096770 0.097067 0.09734 . $0.097 \mathrm{~ns}$ $0.0974 h 1$ 0.097090 0.0913 $0.09 n s$ in 0.09070 $0.09 n$ . 0.09226 0.09317 0.0995 $0.090 \mathrm{n}$ - ogsis 0. $0.100 z$ ar 0.100000 0.1003 is 0.100830 0.10076 0.10044 0.100917 0.101002

SPEC nent sing

- 14 rasta 0.143615 0. 1918

o. mivise

n. intias

O. Inites

o. iniso'

$0.1 ; 0$ ans 0.117010 0.110010 - impras 0.14910 D. 16753

0. 16etes

0.161240

0.142015

0. in 079

0.1596 .6

- is 10

- 157rto

o. 1ent Is

0. 13s/ra

n. iseios

- ingsas

6. 1324

0.1918 az

0.

0. Mon

0.104359

$0.10 n 1 i 0$

Ond

0.109

0. 10 anoo

0.105472

10yoz

0.10324 

5:

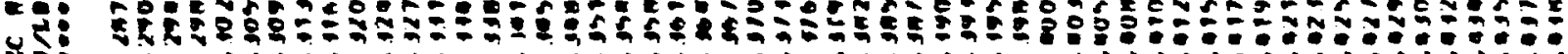

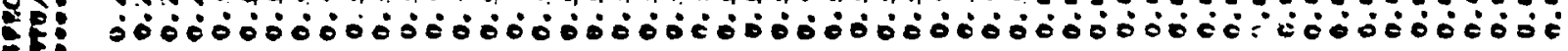

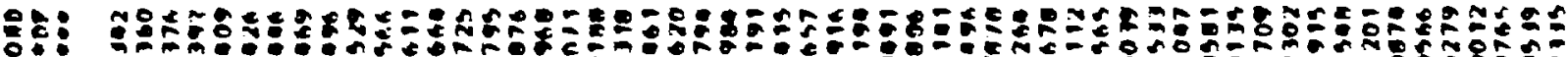

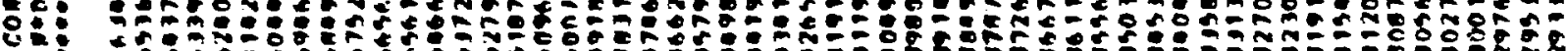

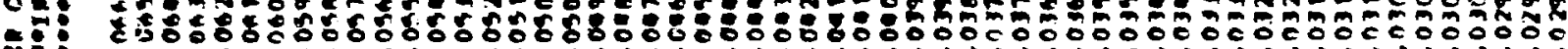

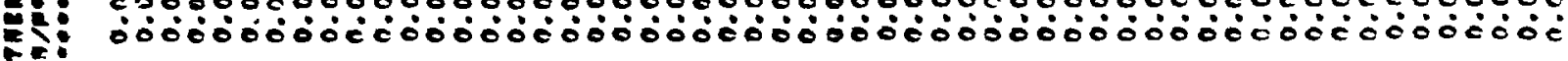

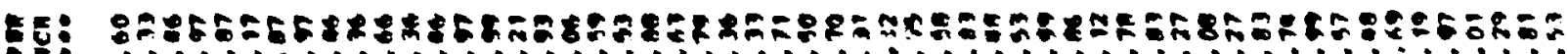

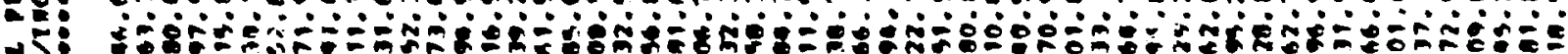

है:

$E:$

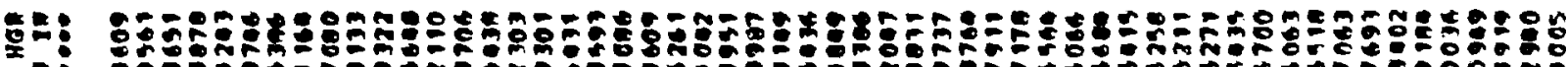

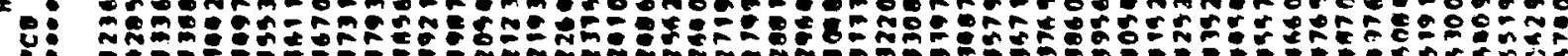

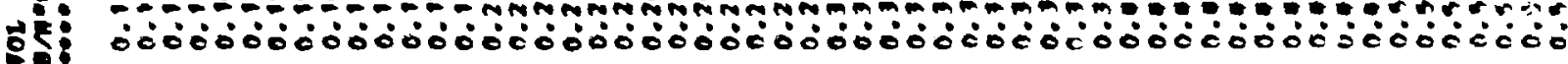

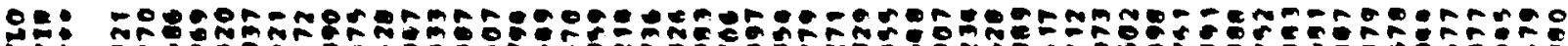

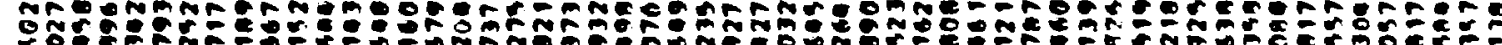

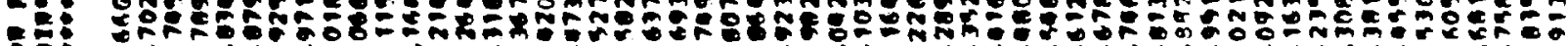

\&: E:

:

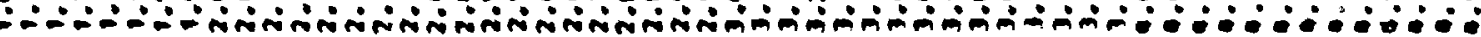

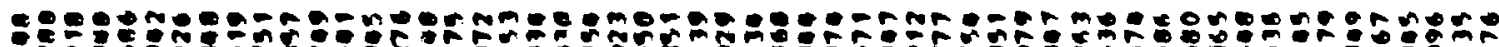
EFO

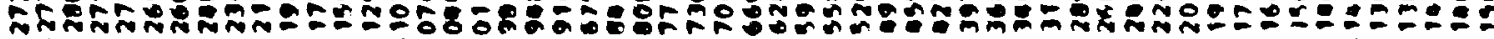

:E:

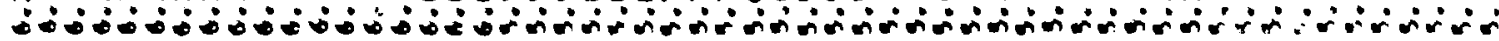

:日:

$+8$

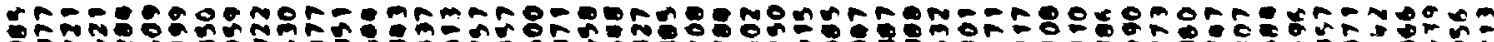

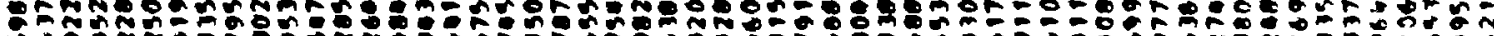
Z825.

in:

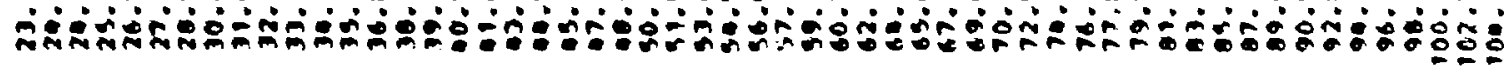

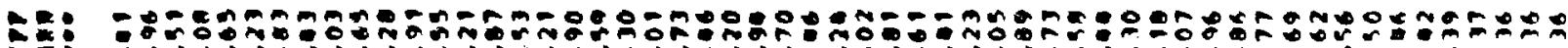

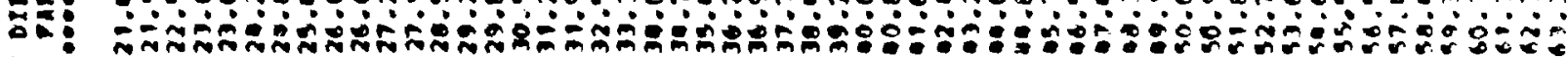
$8:$ E:

E:

:

:

乎

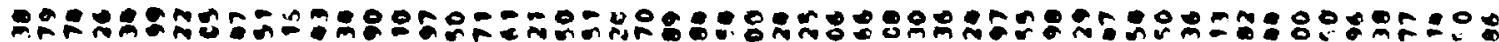

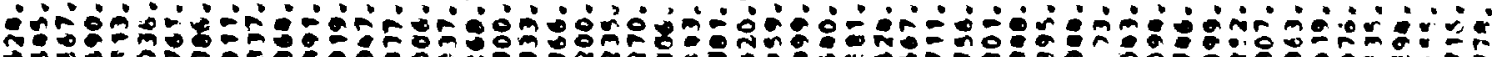

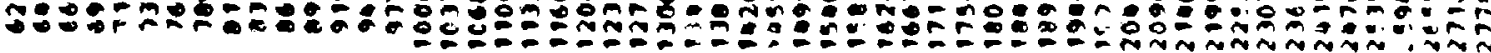

Es:

:

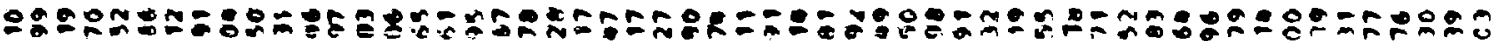

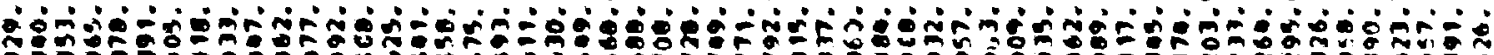

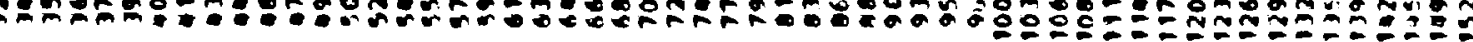

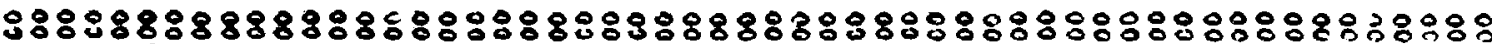
4 :

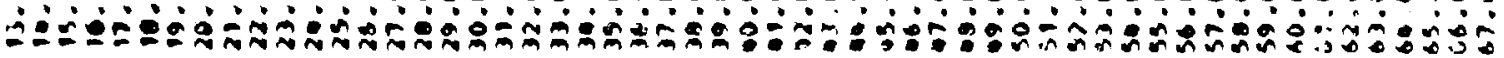




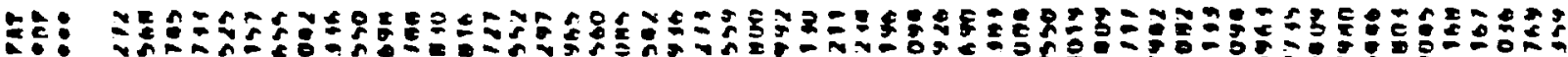
पㄹ :

ZOFFENGRF

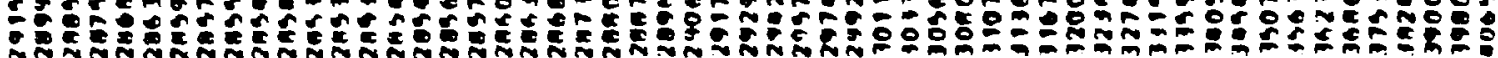

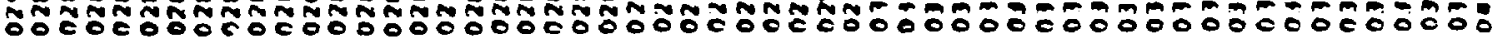

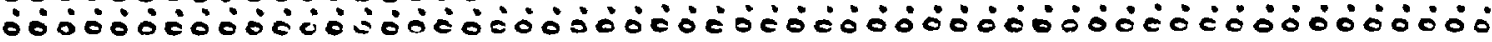

Eㅜㅇ

$5:$

:E:

C:

룰용

-

을

दह

운른

드을

8 8.

늘

른

of:

옹응

둘:

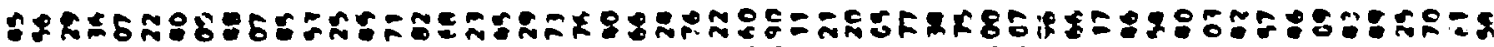

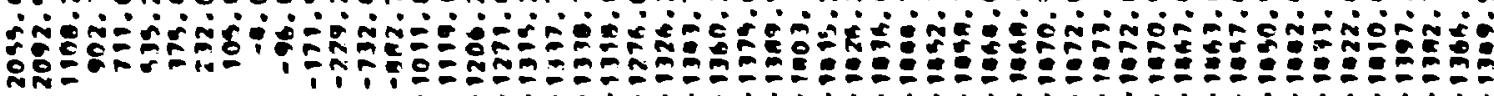

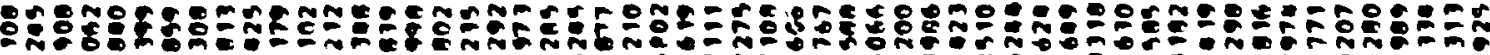

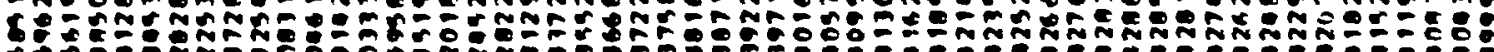

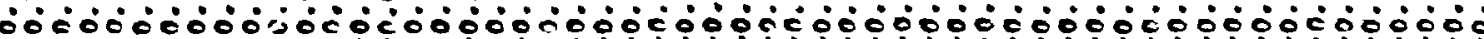

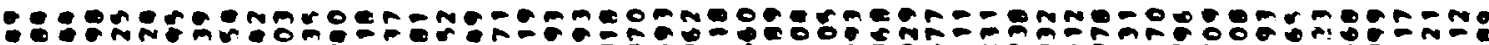

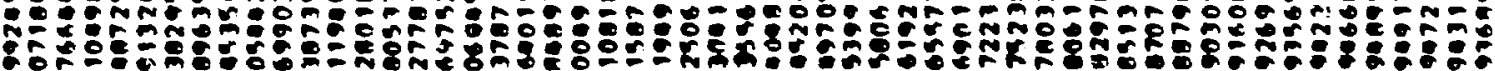

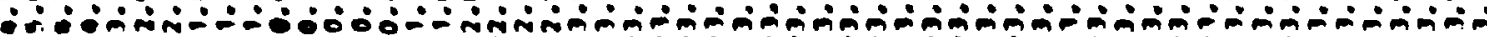
1.

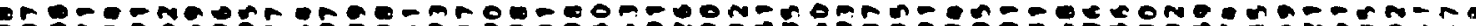

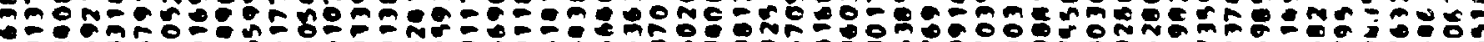

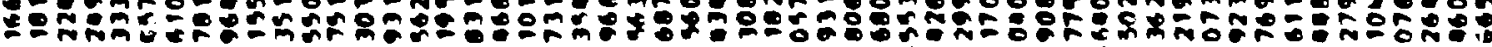
n-

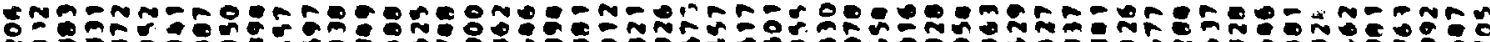

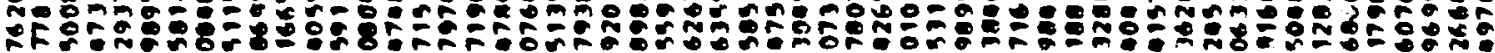

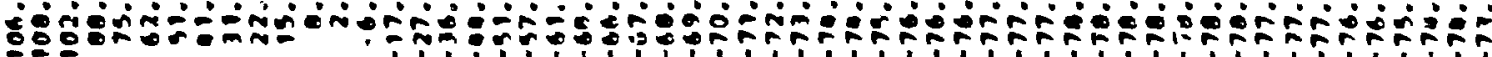

- $=$

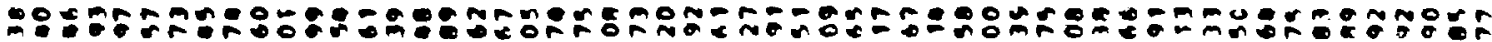

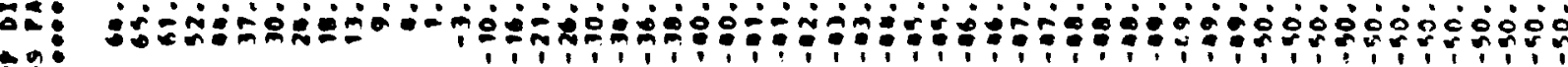

웅:

ㅌ:

:u:

a:

- $1 \div$

ล8์

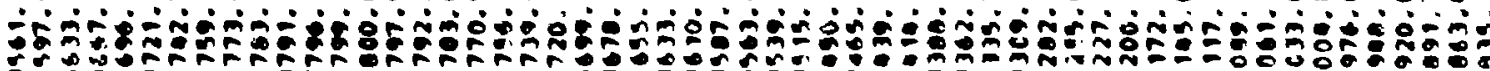

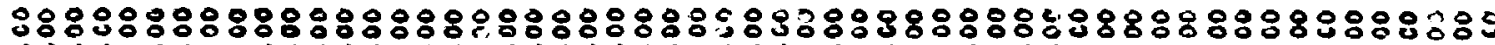

$\stackrel{0}{\rightarrow}:$

을:

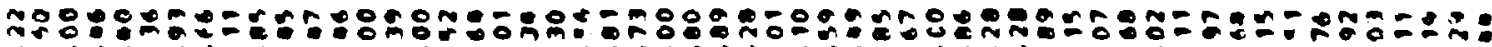

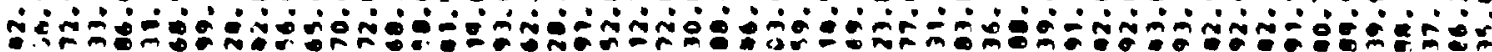

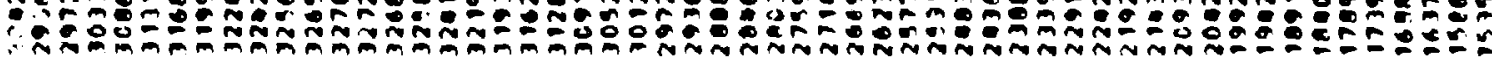

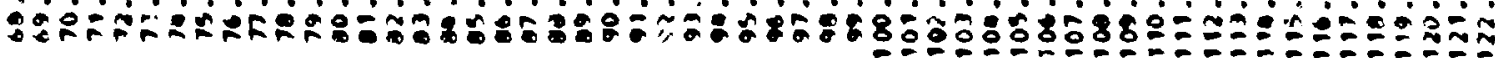


50:

68

8

옹

c:

룽

동

호용

E:

Et:

오:

5:

$8:$

후요

옹:

눌유:

8요

룽

둘

동:

드를

드유:

옹요

뭉:

동

E:

:

가둥:

o

들:

토:

6

인

त)

a:

일

FEz

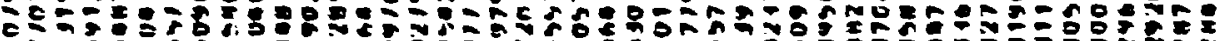

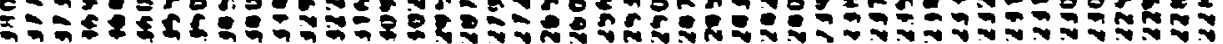

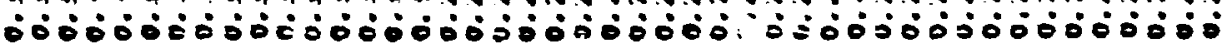

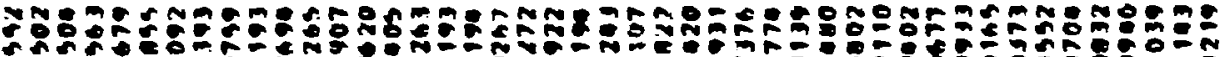

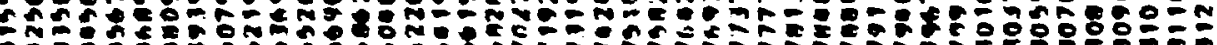

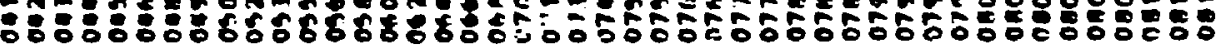

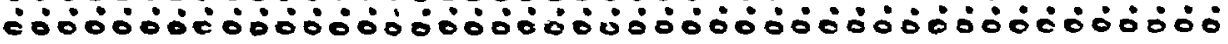

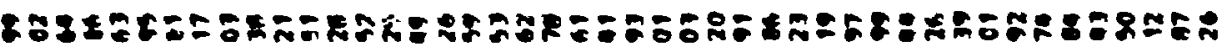

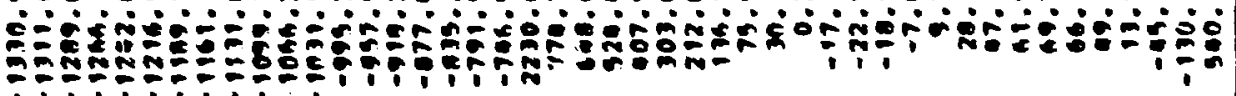

ch

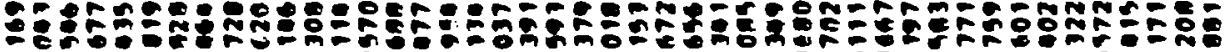

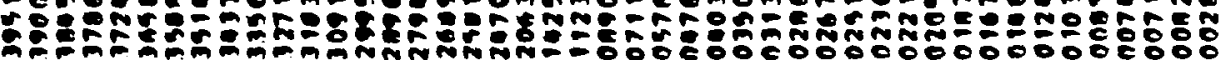

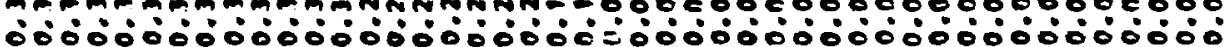
ipipipipipipipipipipipipipipipipipipipipip

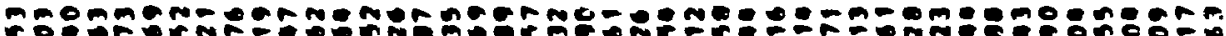

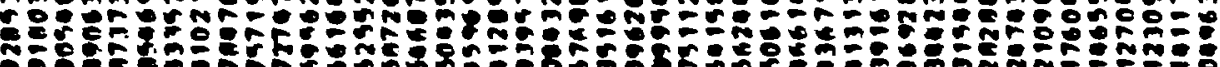

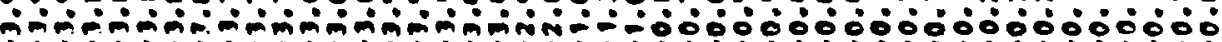

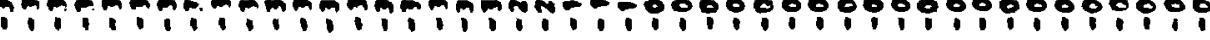

89:Bล5.

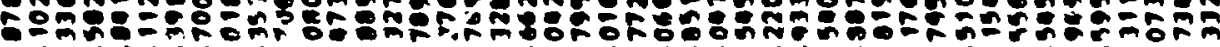

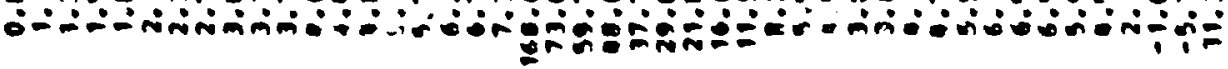

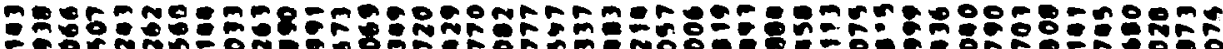

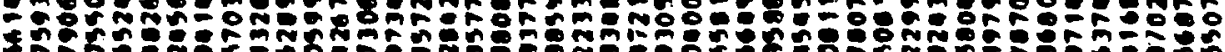
(1)

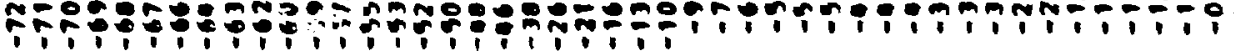

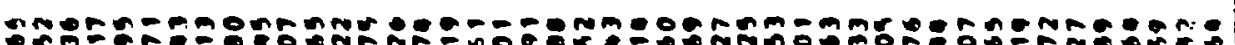
: ópó

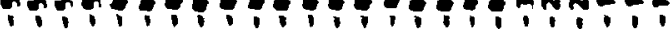

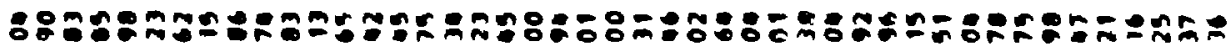

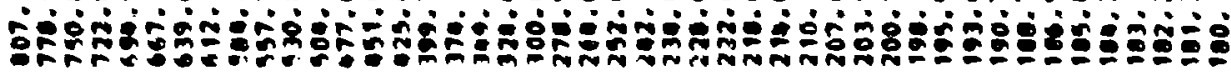

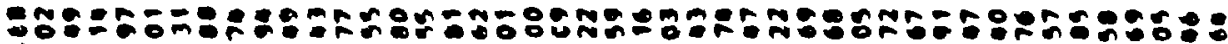

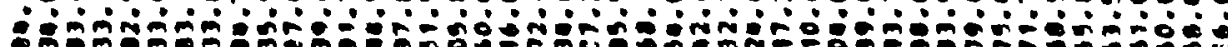

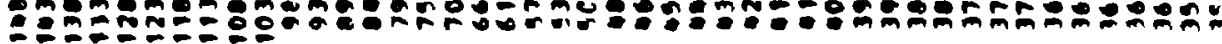

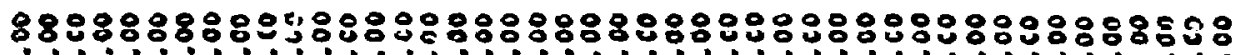

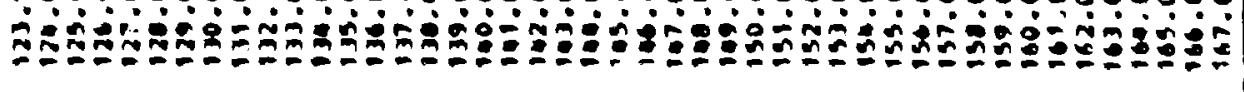




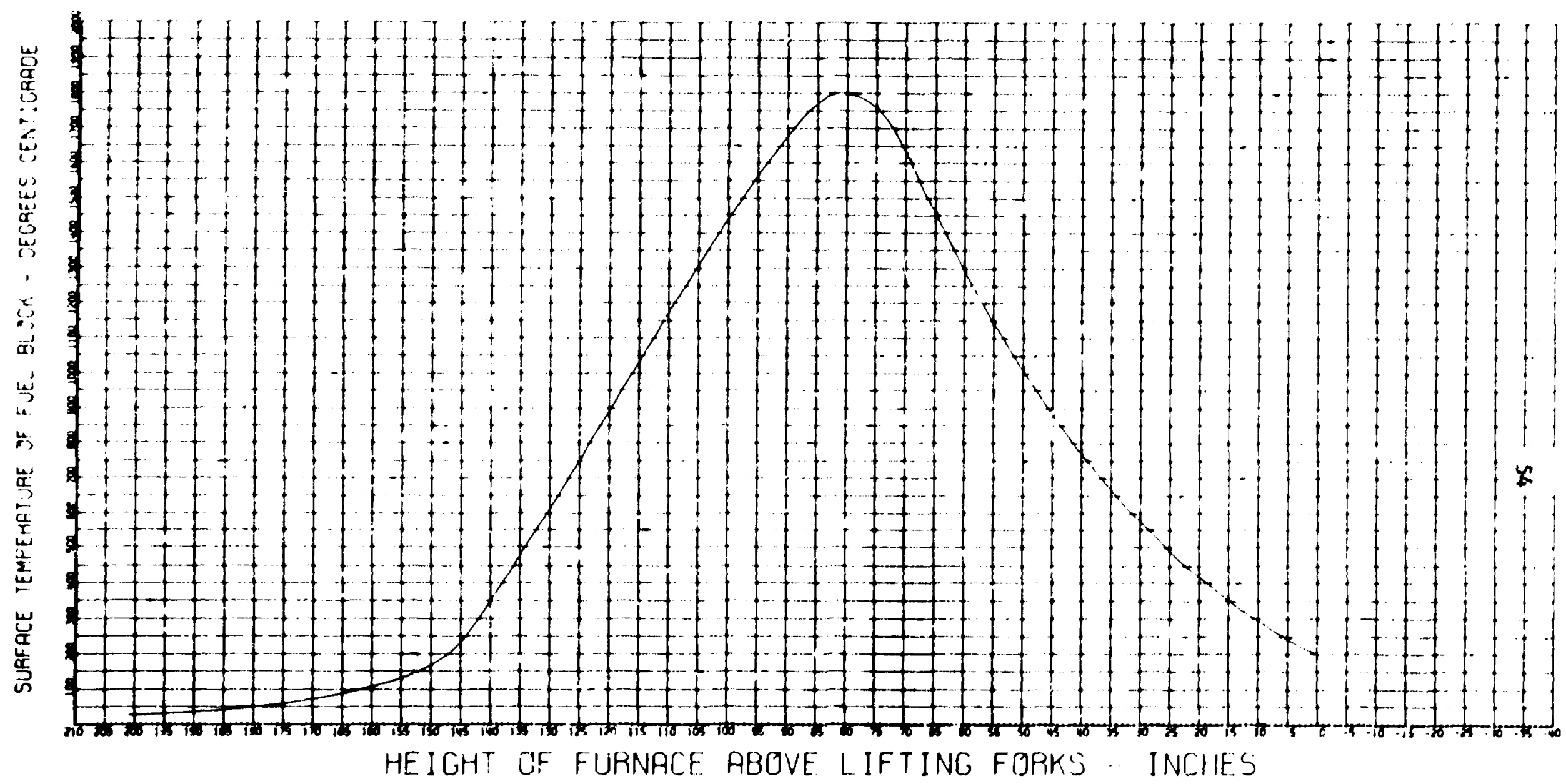

Fig. A.1. Centigrade Temperature Criterla for the Surface of Puel Elements Pabricated Prom H-327 Graphite as a Function of Their Axial Postion in the Furnace for the Top-Loaded Configuration. 
SURFACE TEMPERRTUAE OF FUEL BLOCK - DECREES FAHRENHE!T

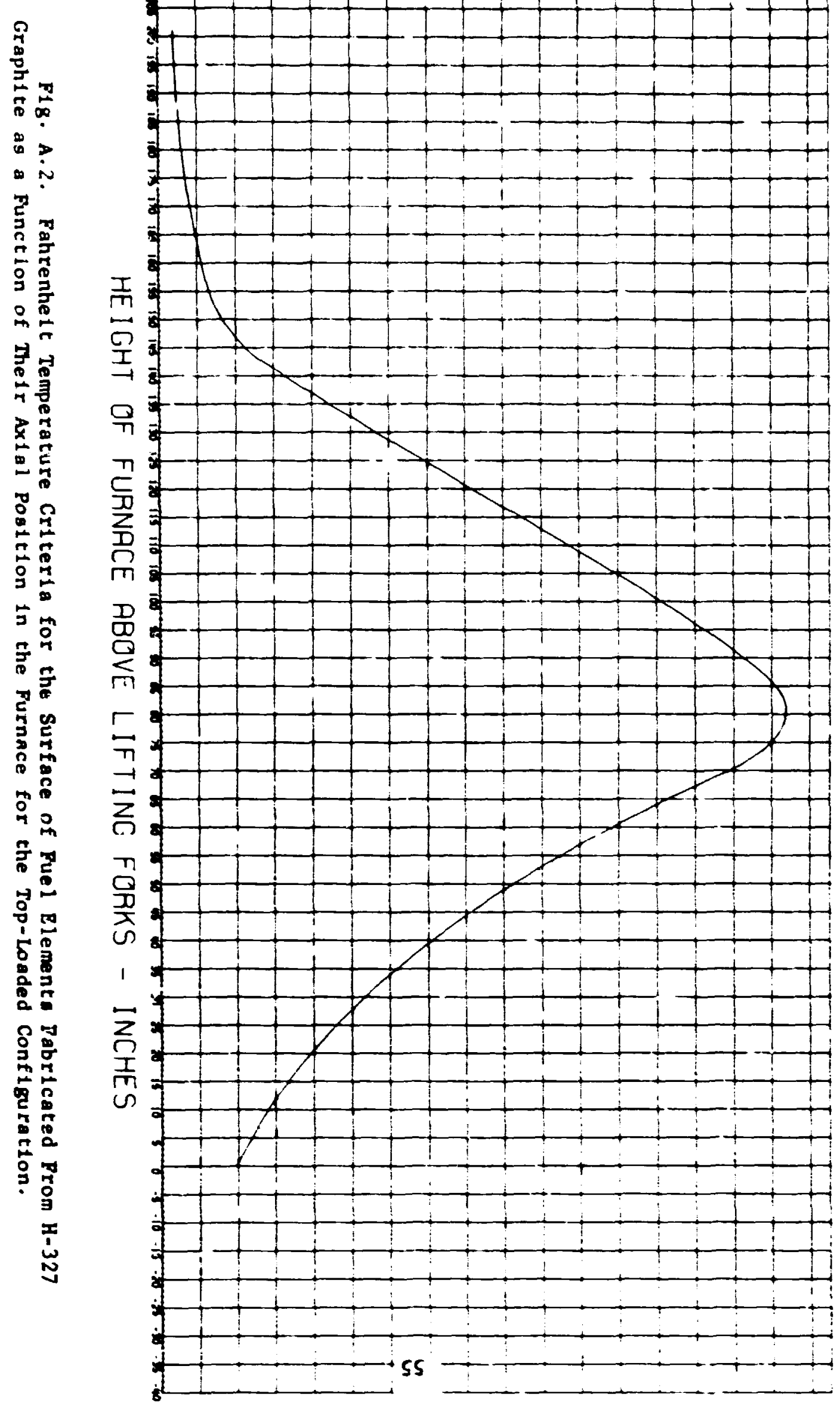




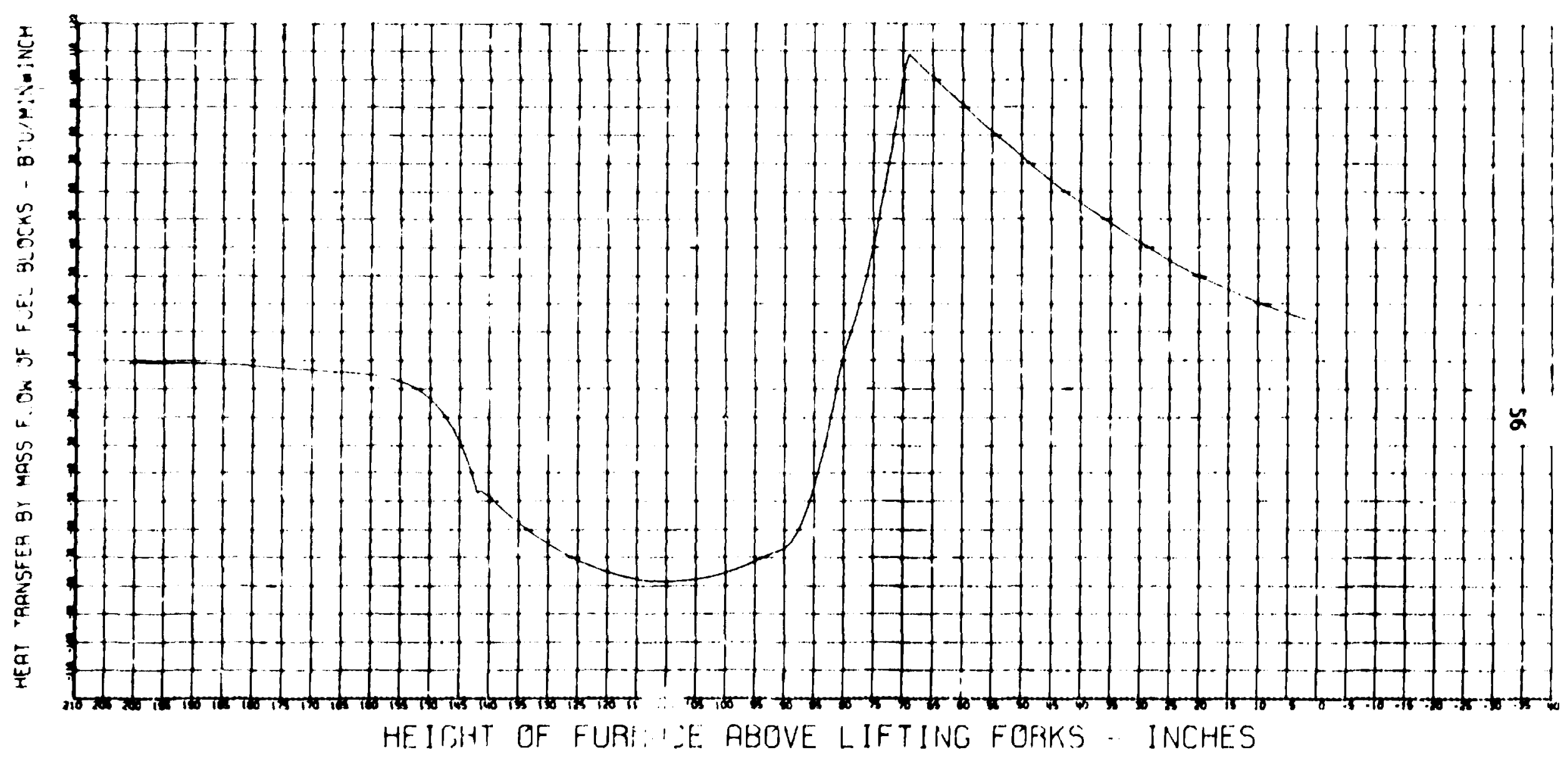

Fig. A.3. Axtal Heat Tranafer From Mass Flow of Fuel Elemente Fabricated Fron H-327 Graphite as a Function of Their Axtal Position in the Purnace for the Top-Loaded Configuration. 


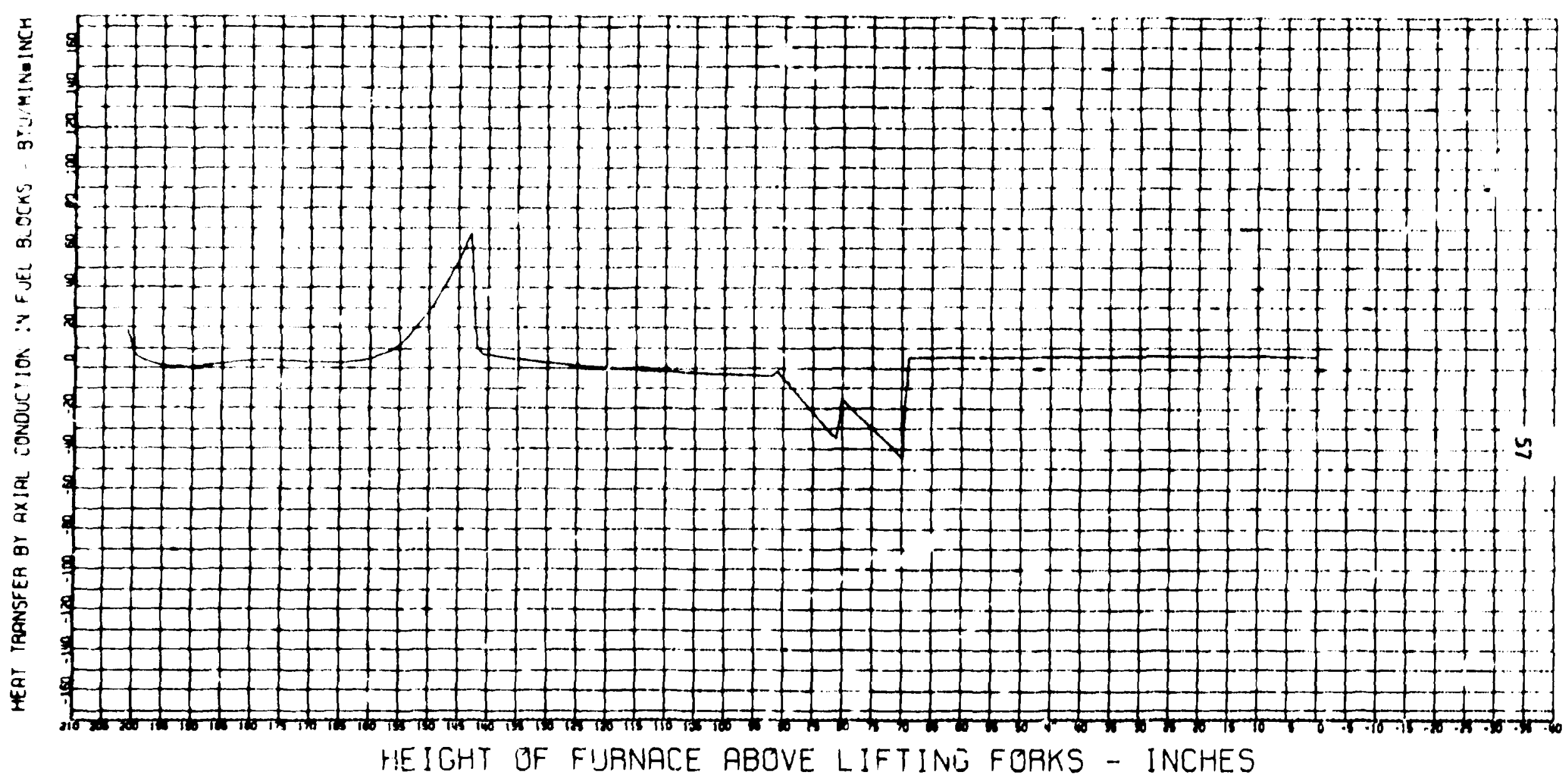

Fig. A.4. Axial Heat Transfer From Axial Conduction 1n Fuel Elements Fabricated From H-327 Graph1te as a Function of Their Axial Pnation in the Purnace for the Top-loaded Configuration. 


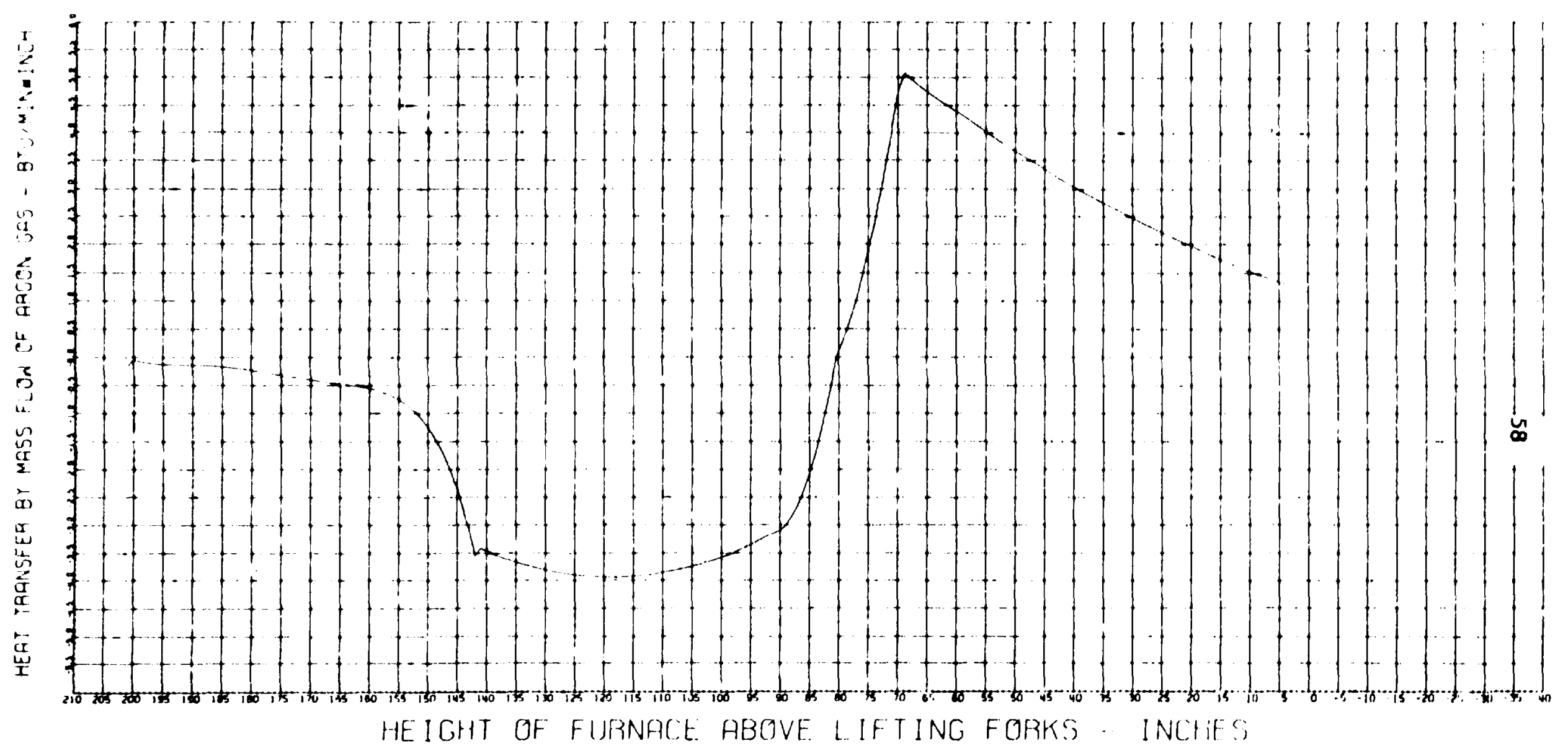

F1g. A.5. Axial Heat Trangfer From Mass Flow of Argon Gas as a Function of Axial Position in the Furnace for the Top-Loaded Configuration. 


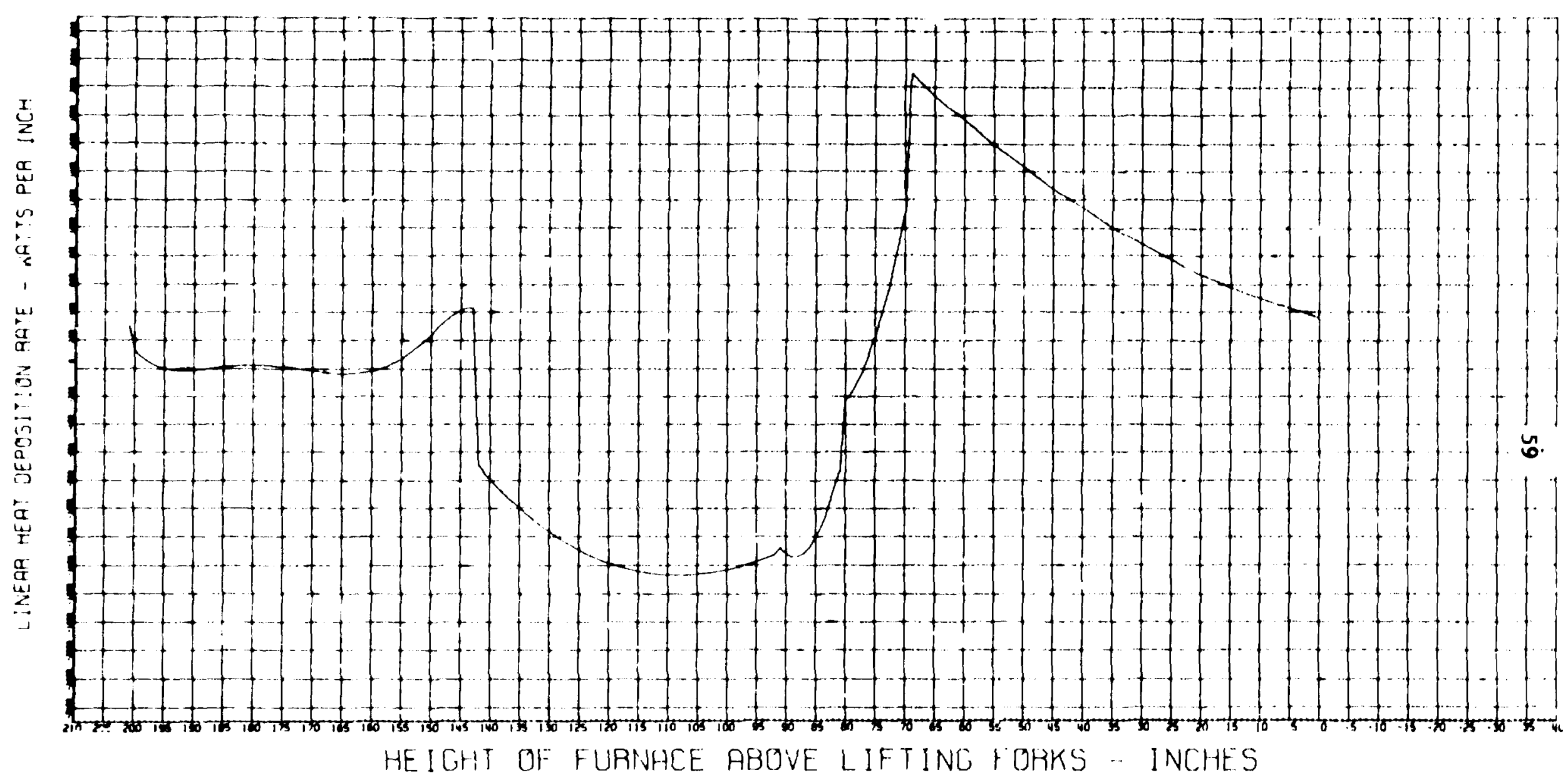

F18. A.6. Total Radtal Power Input, Excluding External Losses, Requ1red to Process Fuel Elements Fabricated From H-327 Graphite as a Function of Their Axial Position in the Furnace for the Top-Loaded Configuration. 


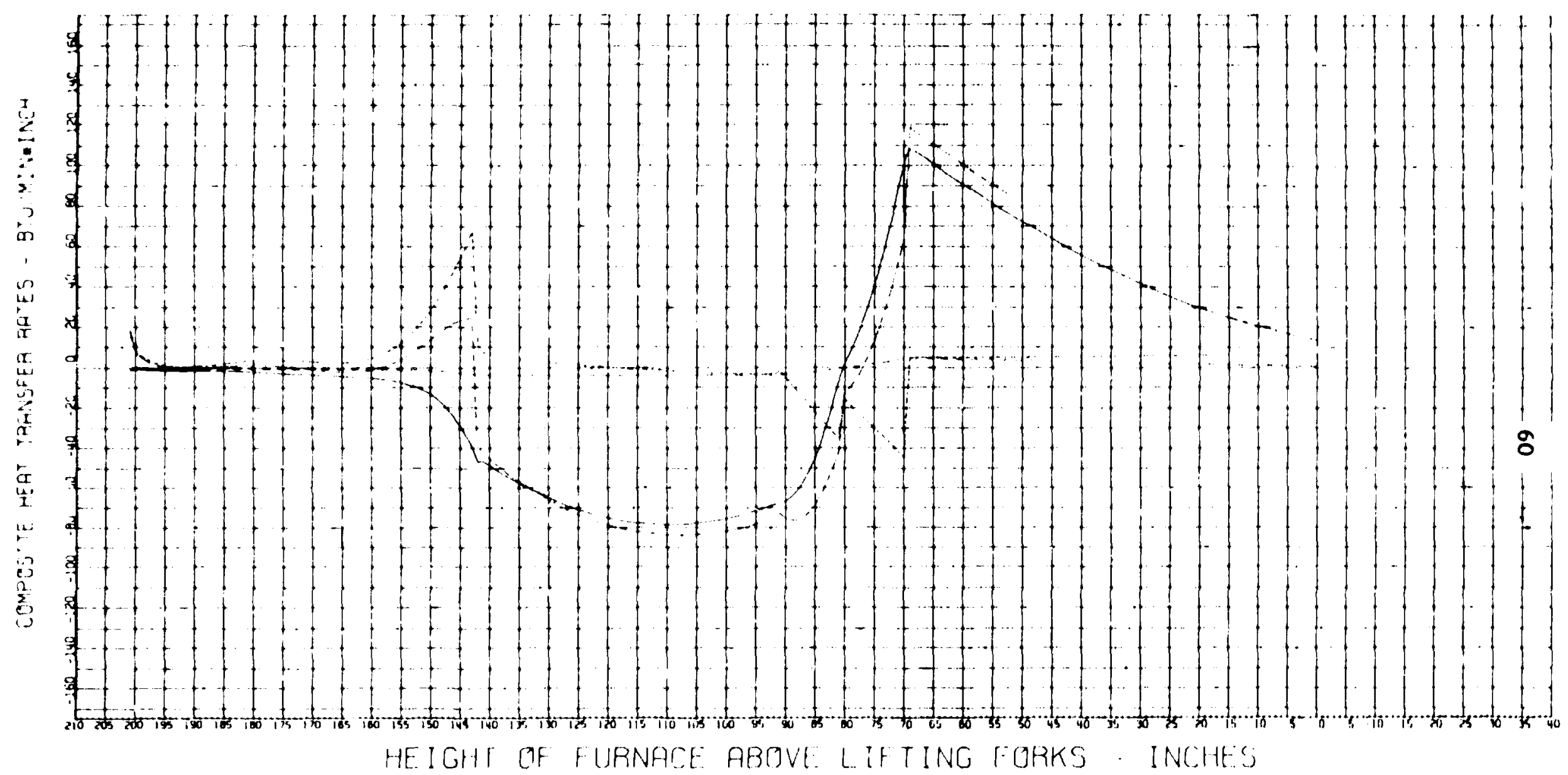

Fig. A.7. Composite Axisl Power Distribution for Processing Fuel Elements Fabricated From H-327 Graphite as a Function of Their Axlal Fosition in the Furnace for the Top-Loaded Configuration. 


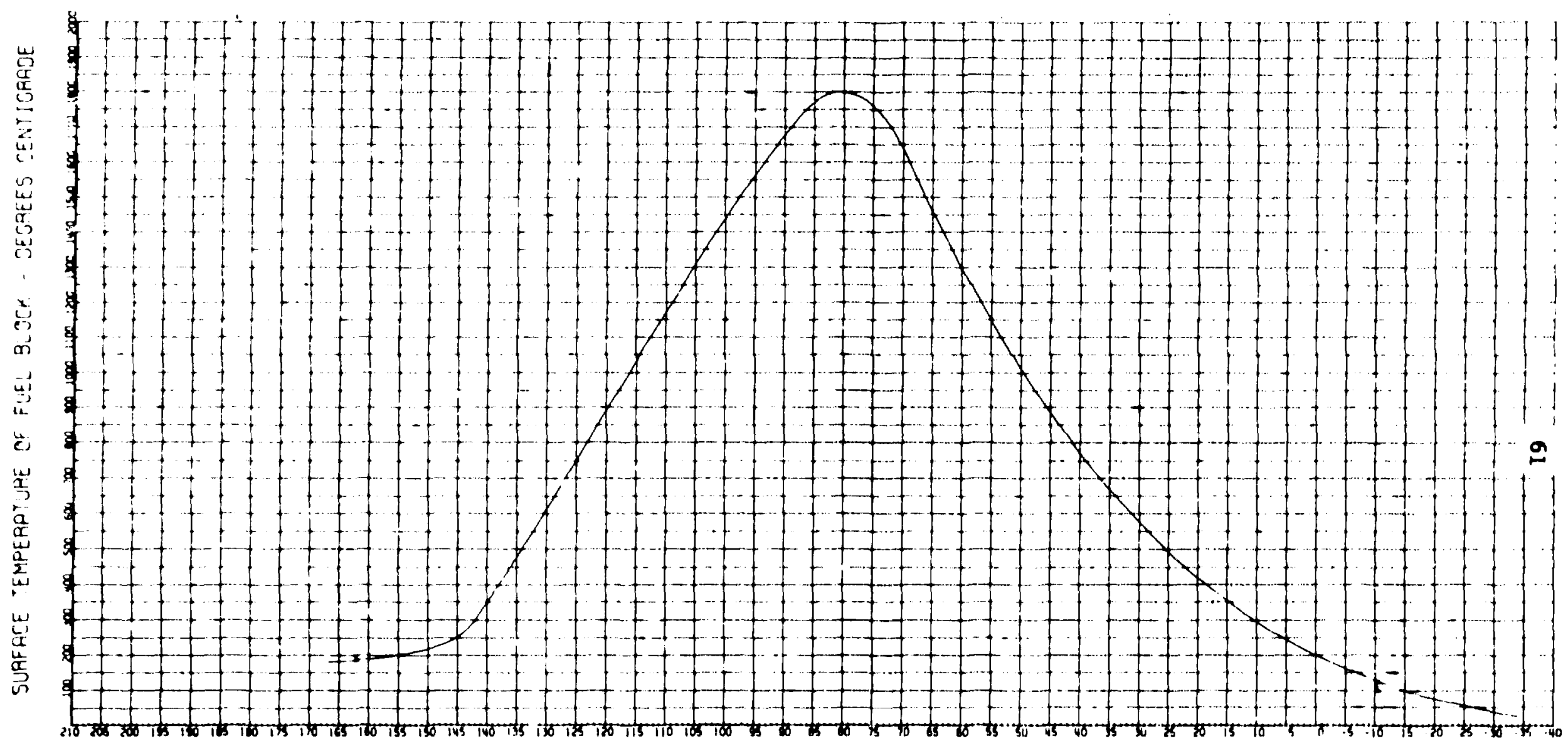

HEIGHT OF FURNACE ABOVE LIFTING FORKS - - INCHES

F1g. A.8. Cent1grade Temperature Criterla for the Surface of Fuel Elements Fabricated From H-327 Grapht te as a Function of Their Axial Position in the Furnace for the Bottom-Loaded Conflguration. 


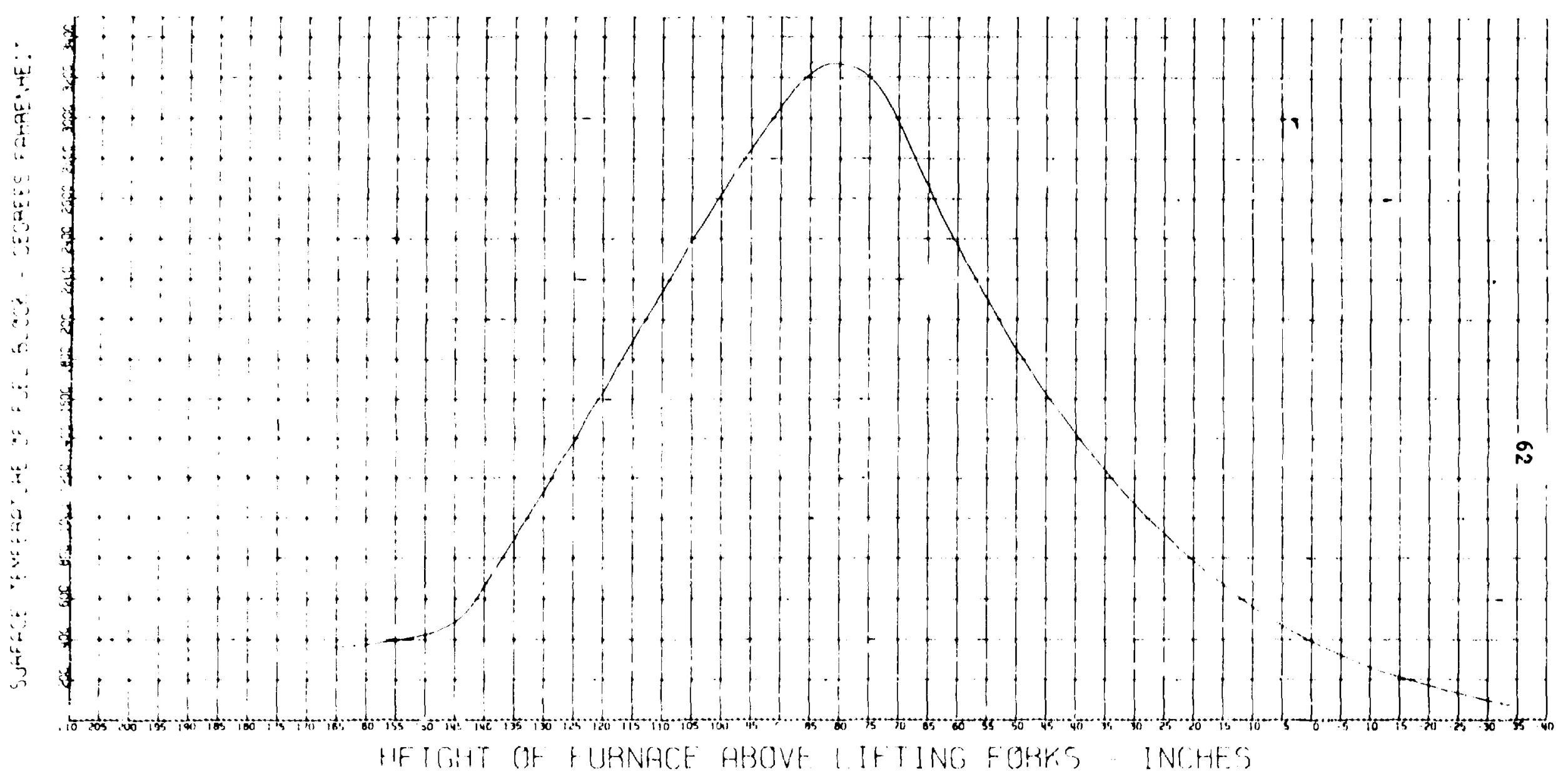

Fig. A.9. Fuhrenhelt Temperature Criteria for the Surface of Fuel Elements Fabricated From H-327 craphite as a Function of Thelr Axial Position ir. the Furnace for the Bottom-Loaded Configuration. 


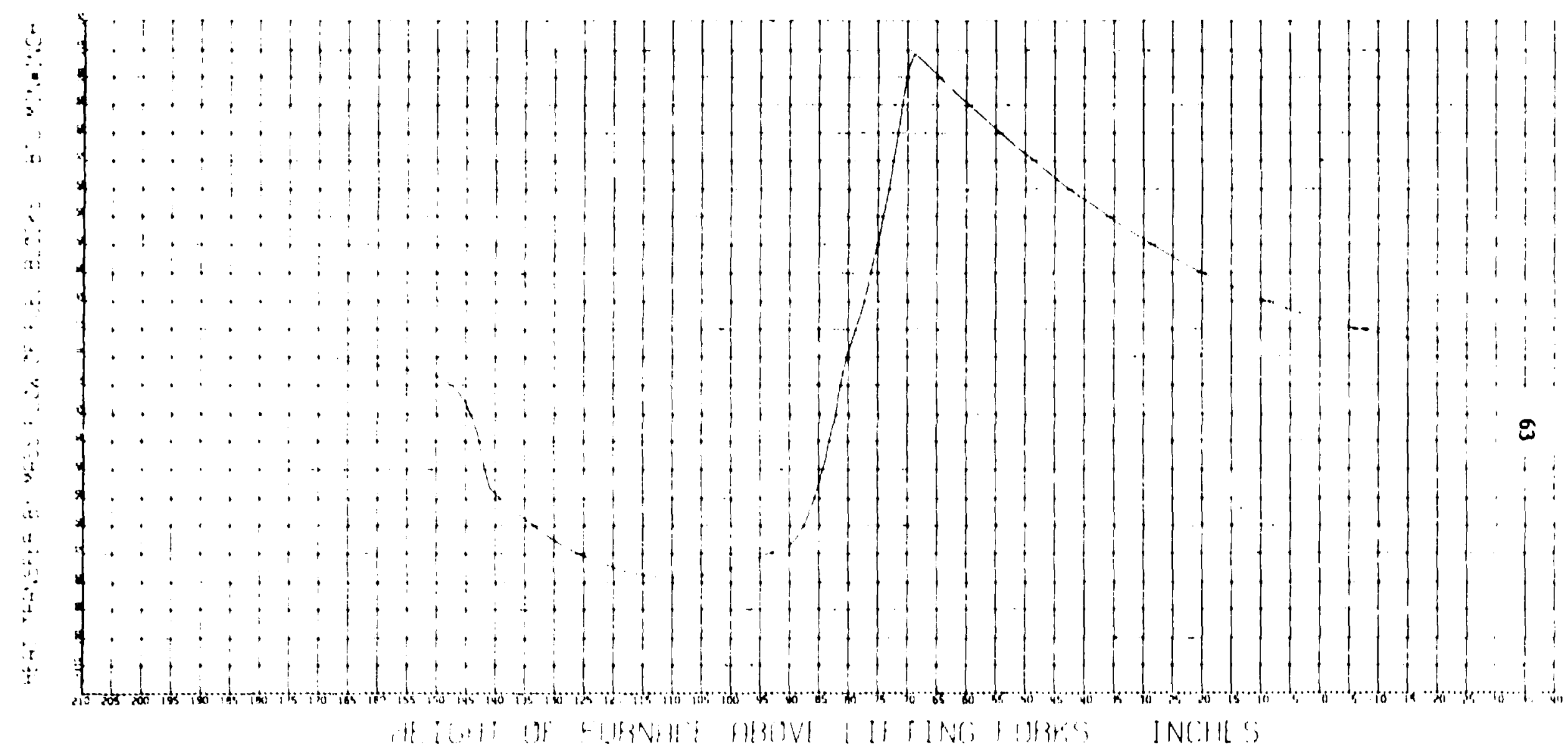

Fig. A.10. Axlal Heat Transfer From Mass Flow of Fuel Elements Fabricited Fcom H-32\% Graph1te as a Function of Their Axial Position in the Furnace for the Bottom-Laded Configuration. 


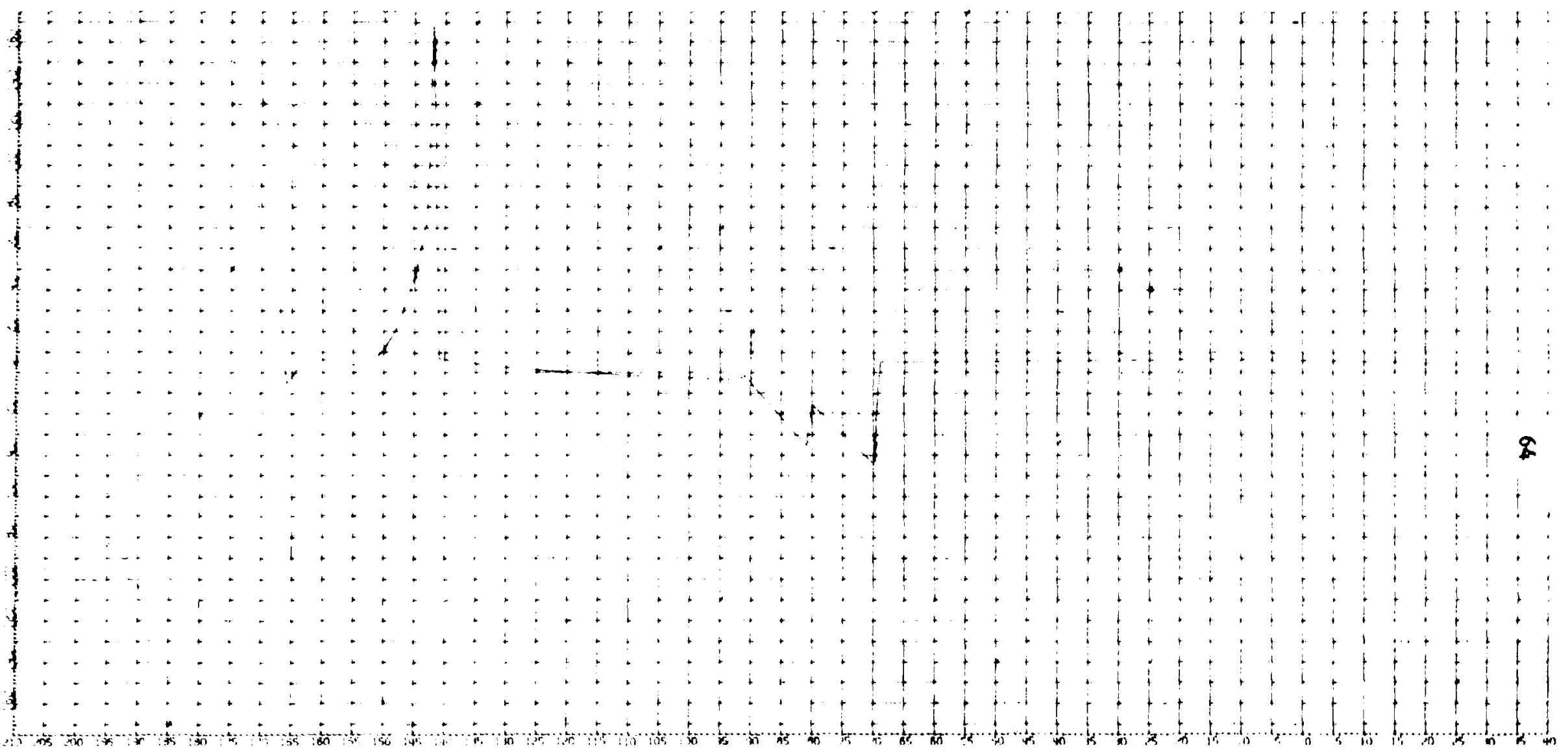

F.s. A.11. Axia1 Heat Transier From Axial Conduction in Fuel Elements Fabricaled From H-207 Graphite as a Function of Their Axiaj Position in the Furnace for the Bottom-Loaded Conflguration. 


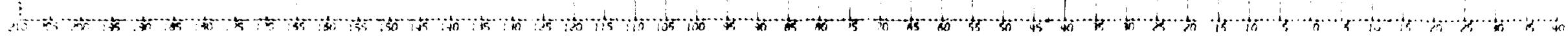

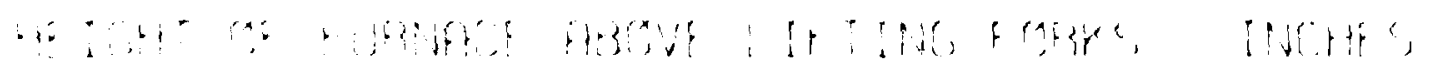

Fig. A.l2. Axial heat Transfer From Mass flow of Argon Gas as a Function of Axtal Position in the Furnace for the Bot:om-Loaded Conftguration. 


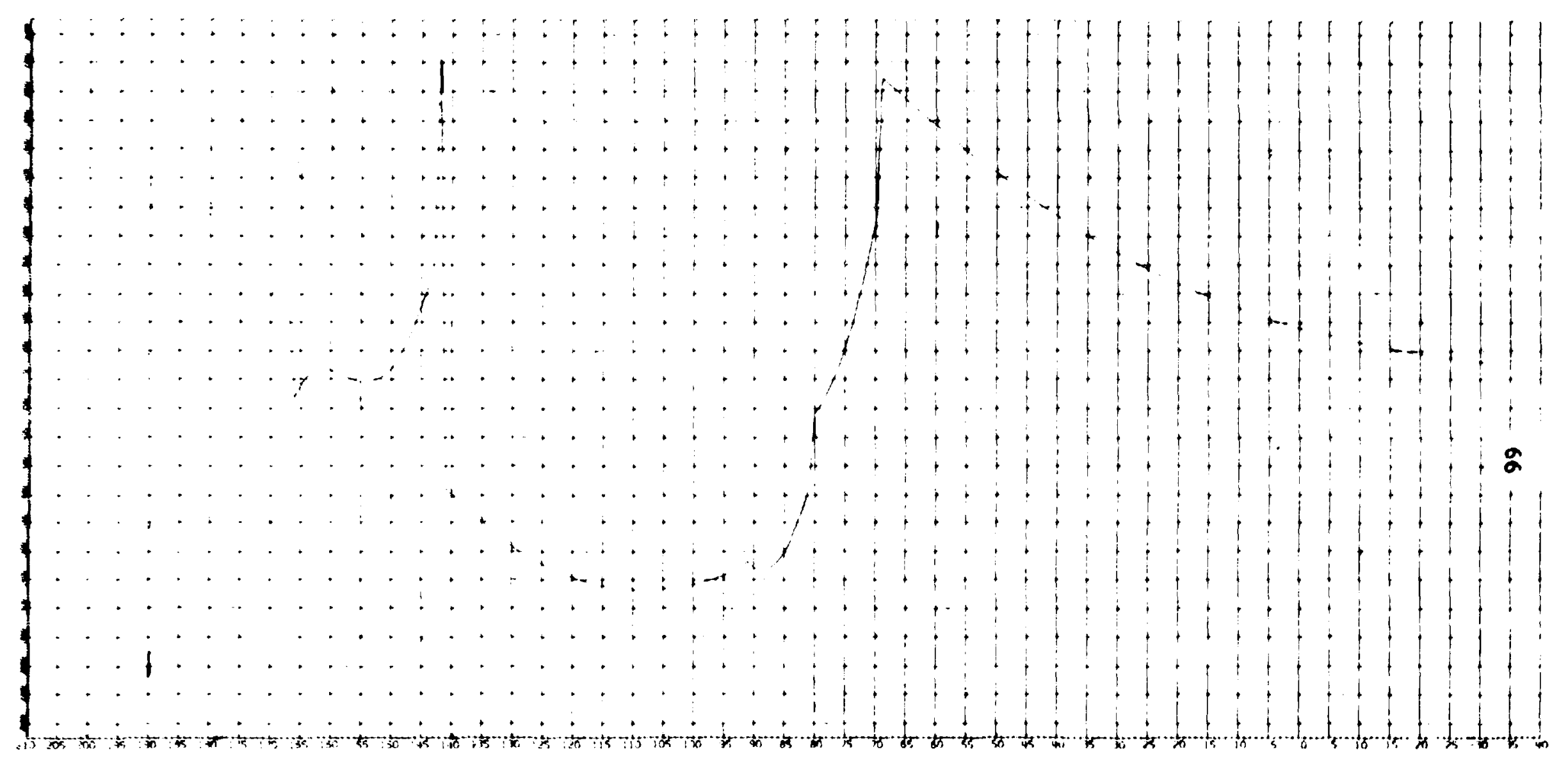

F13. A.13. Totel Radíal Power Input, Excluding External Losses, Required to Process Puel Elements Fabricated From H-327 Graphire as a Function of The Ir Axial Posteton in the Furnace for the Bottom-1oaded Configuration. 


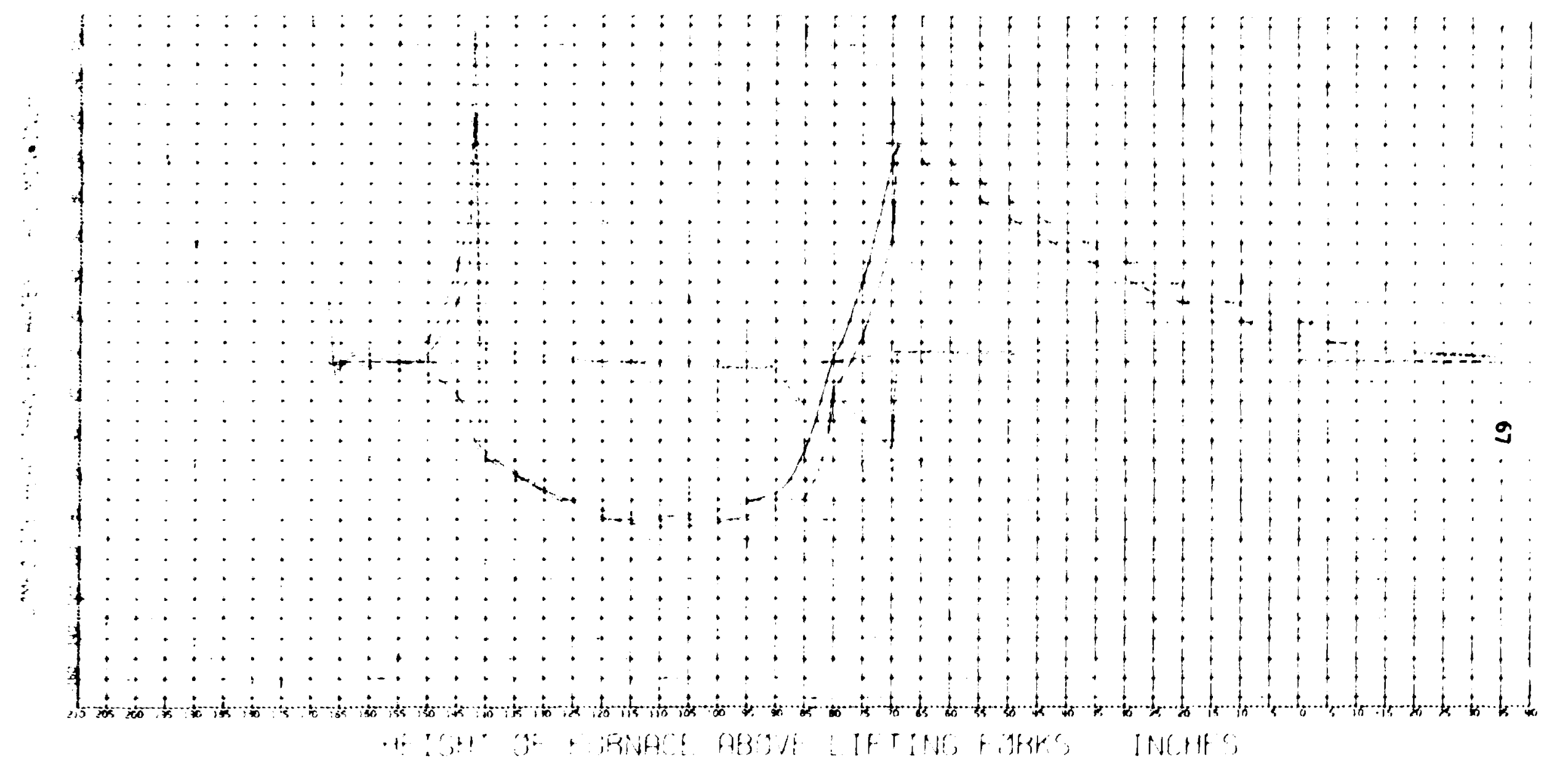

Fig. A.14. Composite Axial Power Distribution fur Processing Fue1 Elements Fabricated Prom H-327 Graphite as Function of Their Axial Position in the Purnace for the Boctom-Loaded Configuraticn. 
Appendix B

MASS-FLON SIMULATION DATA

FOR FUEL ELEMENTS FABRICATED FROM H-451 GRATHITE 
농 블응

4 롱

웅

옹응

웅을

흐룽

도응

8용

-

로웅

통

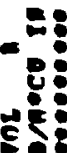

\section{8}

\section{8}

$$
\text { : }
$$

울:

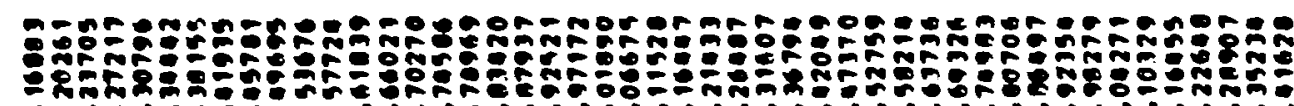

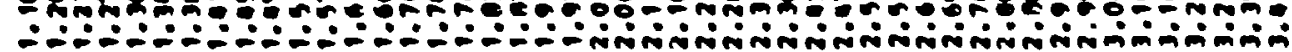

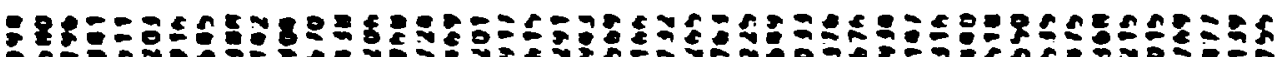

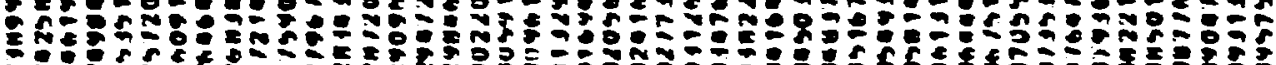

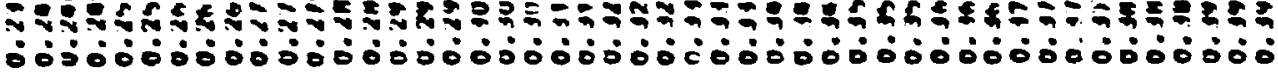

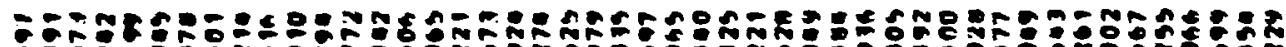

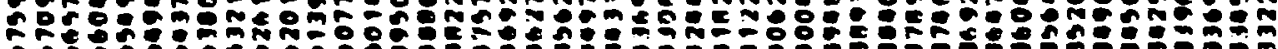
ธ反์

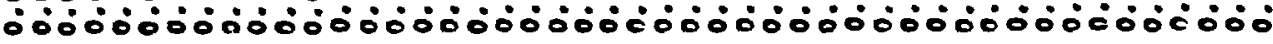

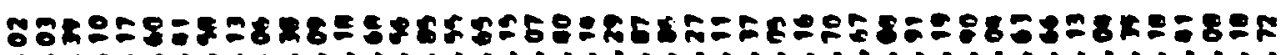

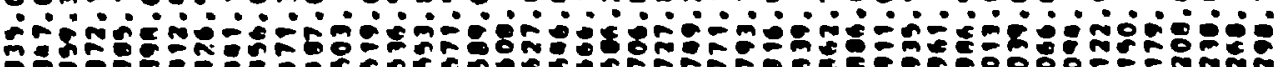

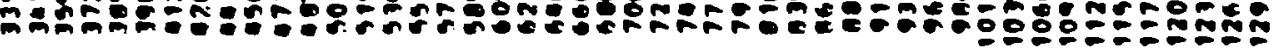

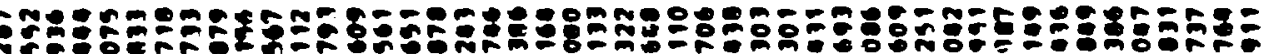

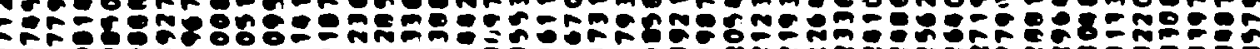

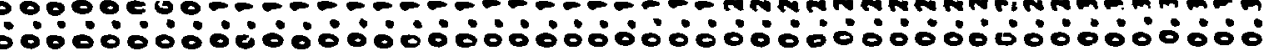

두:

: :

둥

$8:$

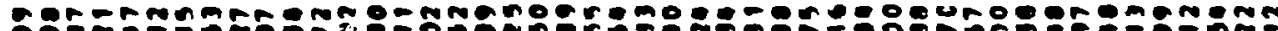

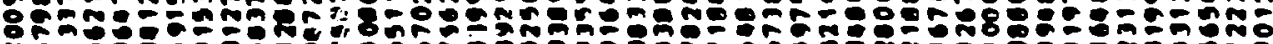

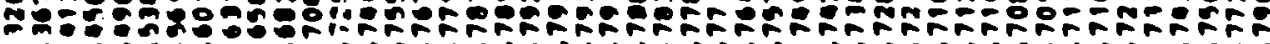

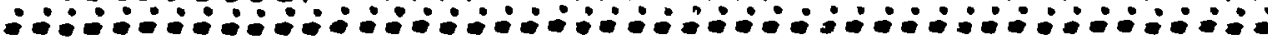

8:

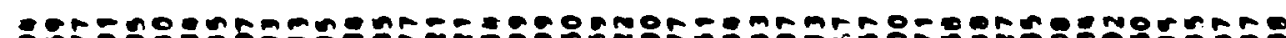

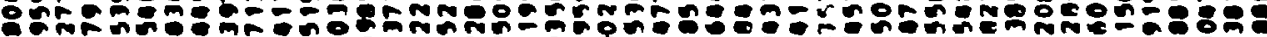

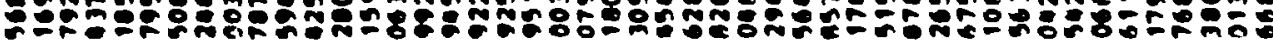

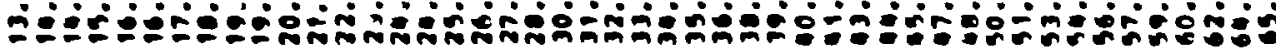

E:

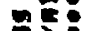

\$8:

6:

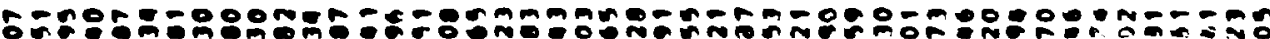

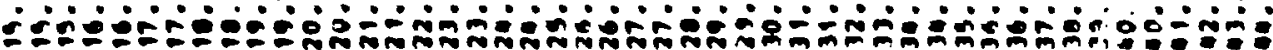

E:

P:

:

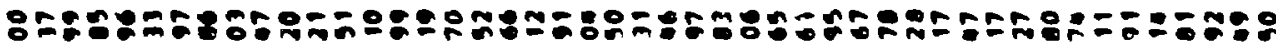

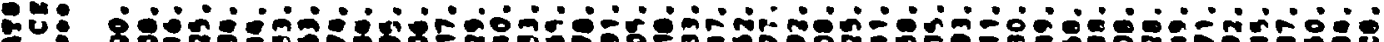
En:

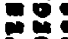

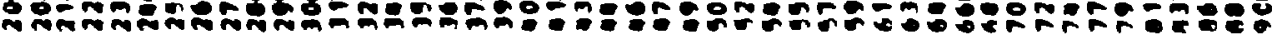

E: :

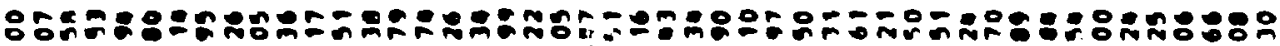
$=:$ :

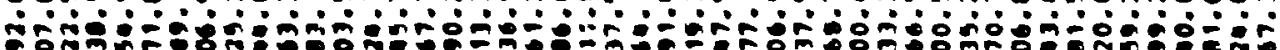

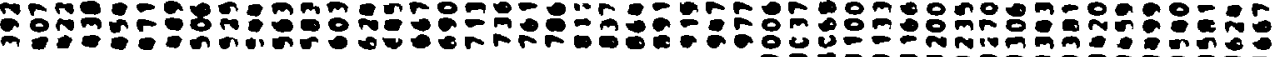

두:

0

0 8888888888888888888888888888888888888888888888

누:

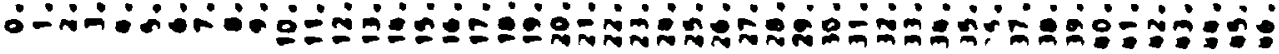


Table B.1 (cont 1 nued)

\begin{tabular}{|c|c|c|c|c|}
\hline 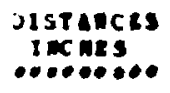 & 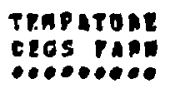 & 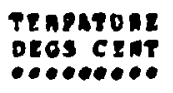 & 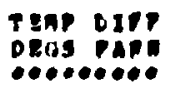 & 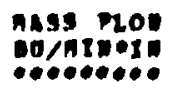 \\
\hline 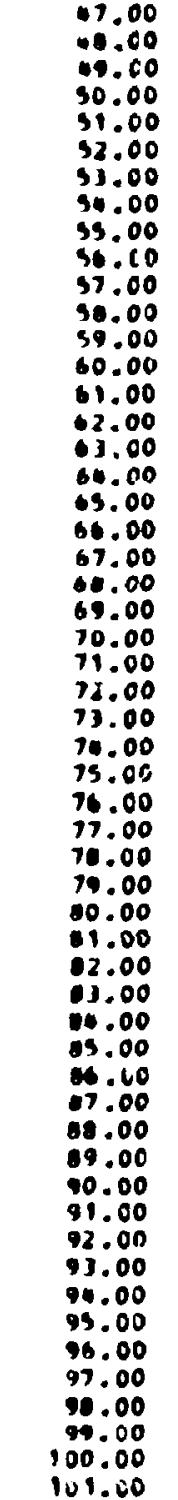 & 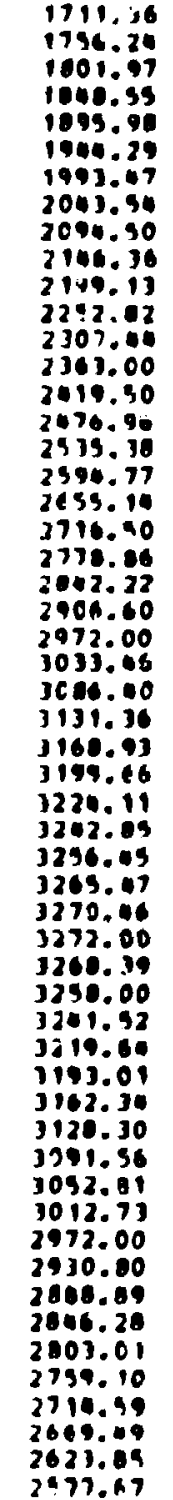 & 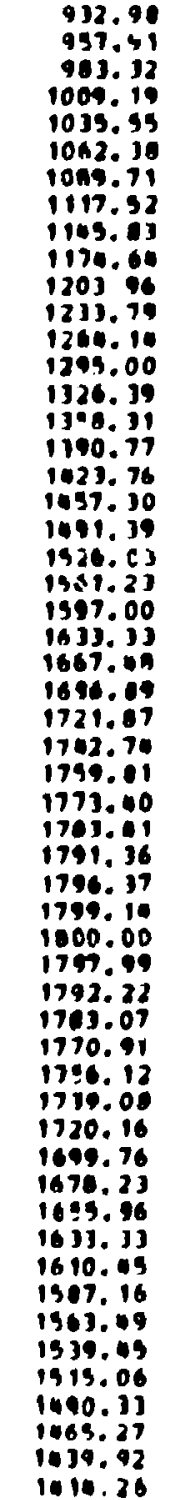 & 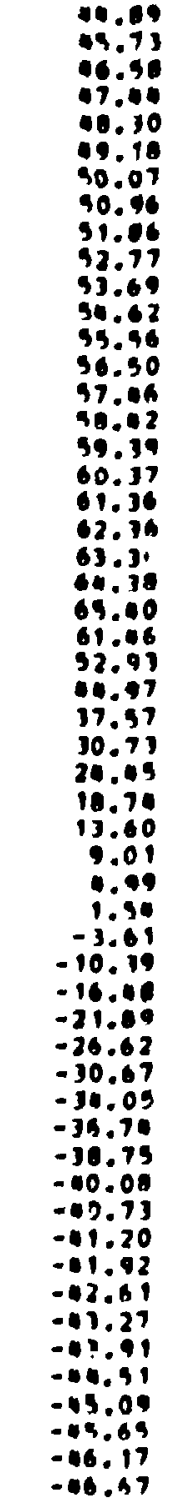 & 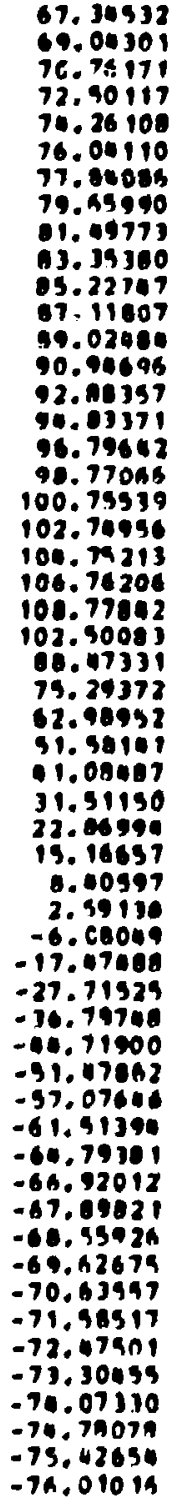 \\
\hline
\end{tabular}

COND MEAT AMGON PLO VOL MRT

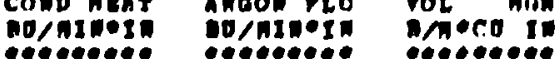

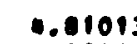

0.0121

0.0550

0.0121

0.9078

.9920

3.02022

3.00776

3.07417

3.12163

5. 14178

3.1589

i.173

$\therefore 16205$

5. 10764

5. 19897

3. 17822

5. 16848

$-03.6996:$

$-10.13391$

$-37.32406$

$-11.32189$

20.96062

$-25.77315$

$-20.32049$

$-17.03530$

19.96630

$-30.17075$

$-27.23000$

-27.2 .9080
-211.09310

-211.09319
-20.95397

$-17.00220$

$-19.6279$

11.42157

- - .0nsis

$-1.34350$

$-3.6507$

$-3.3494$

- 3.32025

$-3.20218$

- .04167

-2.95469

$-2.7050$

$-2.37032$ 3.onnas 3.54619

3.61212

3.74602

3.01398

3.09251

.

0.09293

$0.163 \mathrm{~A}$

0.2331

0.30807
6.30199

0.45478

- 93040

-.60577

0.48177
0.79895

0.01570

- 13140

4.99209

5.07164
6.76560

0.10498

$3.007+9$

2.91324

1. 99639

1.05350

0.69903

0.34714

0.11940
-0.26018

$-0.0033$

$-1.09752$

$-2.3797$

$-2.60 .095$

- 3.1081

- 3. 14a70

- J.1949

- 3.30010

- $3.3556 n$

$-3.40019$

- ]. 4320

- 3.4970

$-1.9006$

$-3.61929$
0.367170

0.376964

0. 3 19.166

0.005415

0.01529.

0.02921

0.03527

0.445435

0.599700

0.464063

0.476310

. EnTens

0.50n 0 02

0.5041918

0.530016

0.340909

0.351919

0.962940

0.570004

$0.5 n$ ion

0.996245

0.561908

0.012000

0.345349

0.212059

0.225100

0.172813

0.083179

0.046102

0.019212

$-0.095839$

$-0.151998$

$-0.201902$

$-0.212292$

- 0 .

$-0.335209$

$-0.366877$

-0.

- .

$-0.317111$

$-0.192279$

-

-0. 011606

-0.509a

-0.11084
-0.016200 onpal pen DATr/IICA

1329.6

131.09

Meno,

$\bullet \cdots \cdots \cdots$

STEC MEAT mincou

os $0.031023 \quad 0.3413264$

$0.01215 n$

169. 0.012221 0.4luall

1957.04 0.0120\%0 0.0127mA

1991.6 0.011437 0.01114

1426.03 0.031710 0.019.24

1660.49 0.031577 0.011012

$\begin{array}{lll}175.63 & 0.031037 & 0.021064 \\ 170.02 & 0.011267 & 0.029012\end{array}$

$1766.290 .031124 \quad 0.01 / 324$

$1001.90 \quad 0.010496 \quad 0.024171$

1117.73 $0.030790 \quad 0.010464$

1973.73 0.0j0519 0.052641

1909. 16 $0.030299 \quad 0.011194 \mathrm{M}$

1946.10 0.030043 0.01114.11

1942. In 0.0247640 .051045

$2 n 16.940 .0294 h$ 0.4shyou

$2093.95 \quad 0.079132 \quad 0 .+4021 d$

$2092.02 \quad 0.029 n 20 \quad 0.161544$

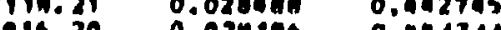

0.023104

0.027920

196.900 .027501

297.910 .027401

136.430 .027246

0.027219

$0.02711 \mathrm{~A}$

0.02719

0.027 in

$-215.45$

-9.0\%

$-894.62$

0.02714

0.037210

0.027311

1190.0

$-1294 . x$

-11).

-13

0.07797

0.02770

0.02797

0.026122

0.021114

- 1270.19

-1724. 7

0.02 sez

0.02179

2.020972

0.029180

0.024379

1390.29

0.024611

0.0298 is

0.010016

- 114.09

14

0.010191

ions. 11 


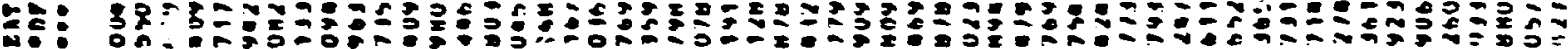

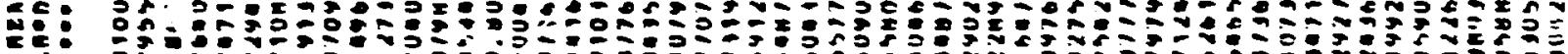

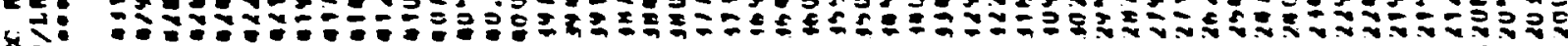

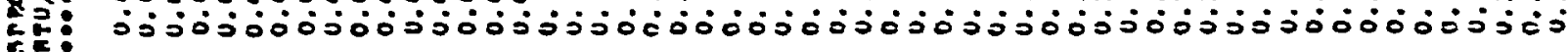

e:

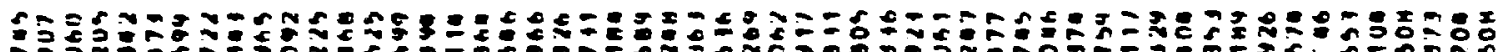

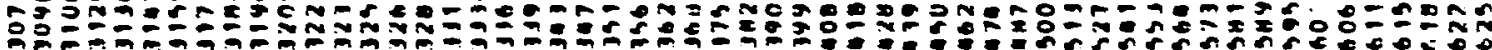

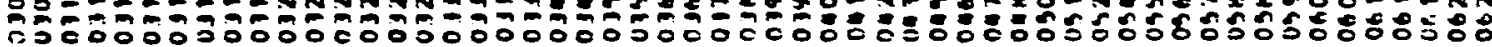

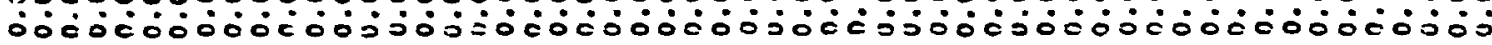

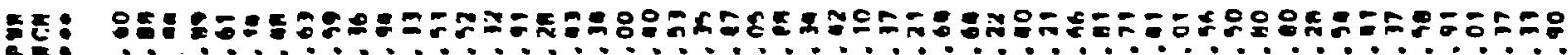
Q ia: C:

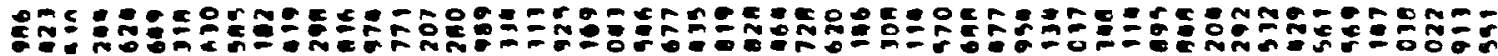

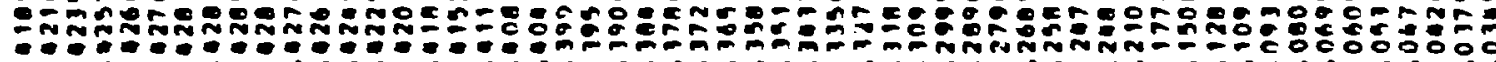

c:

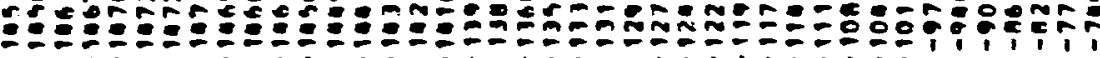

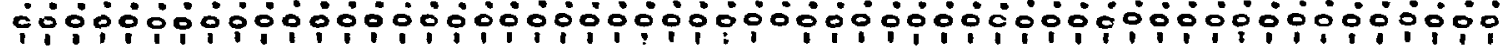

동:

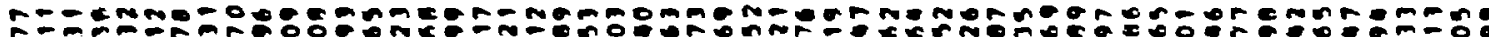

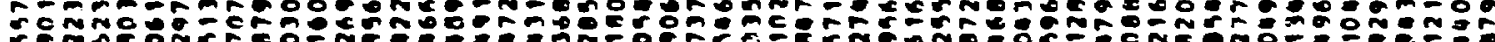

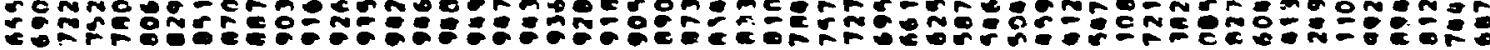

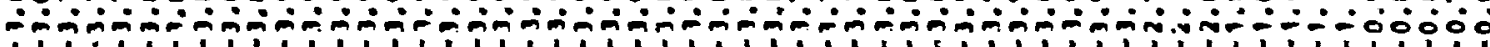

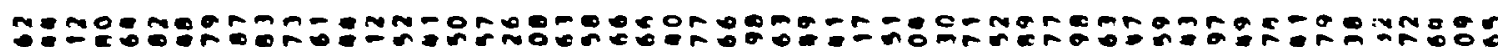

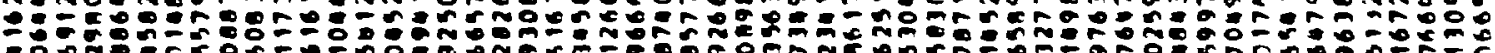

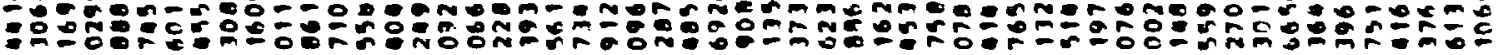

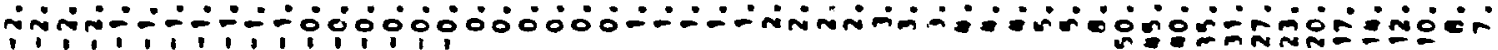

:

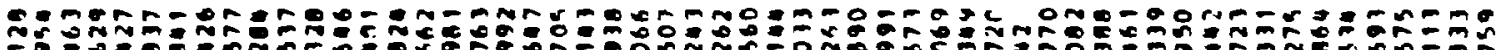

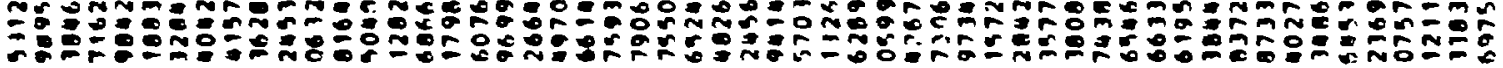

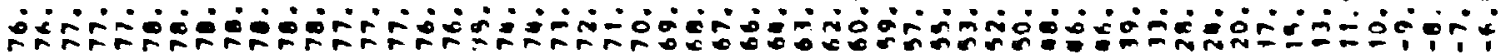

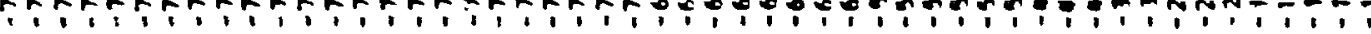

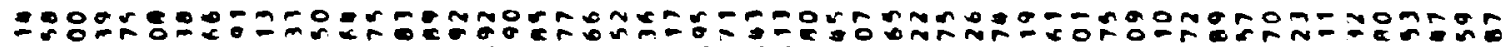
-

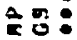

프:

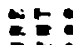

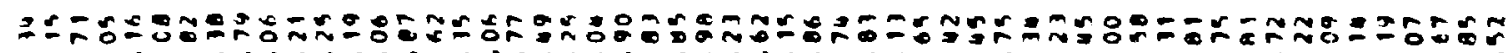

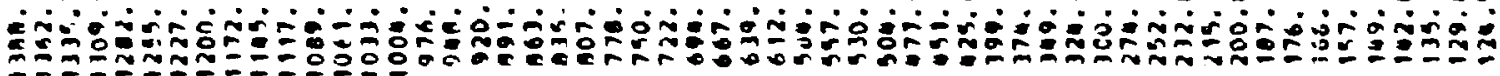

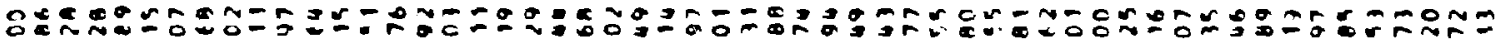

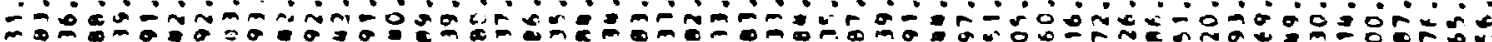

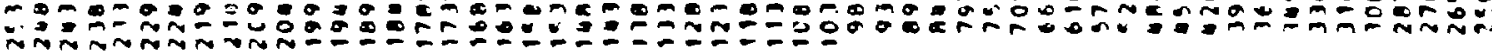

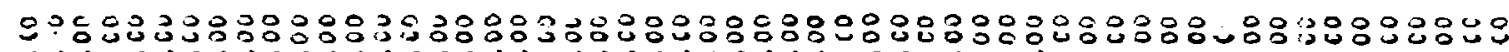

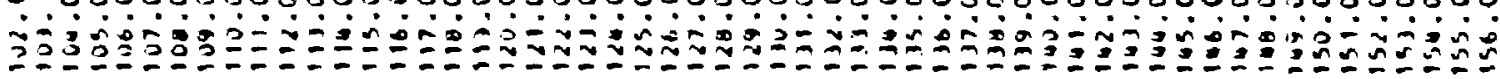




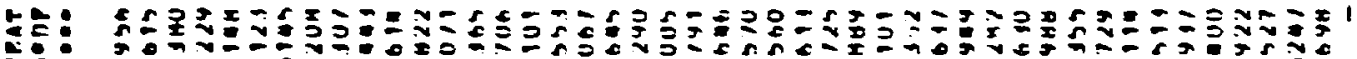

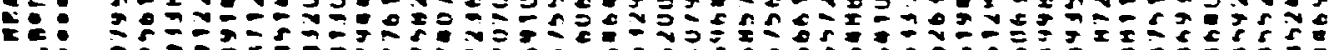

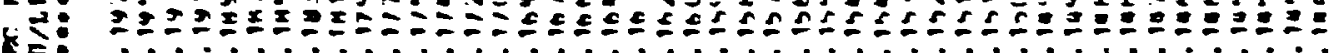

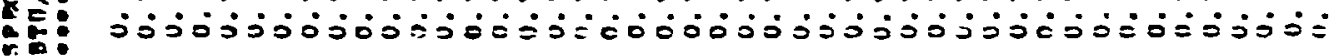

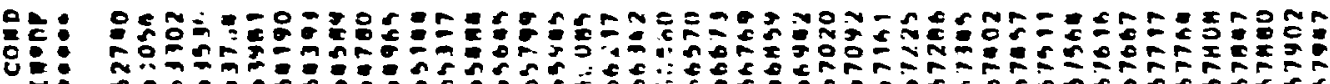

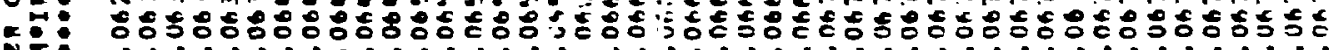

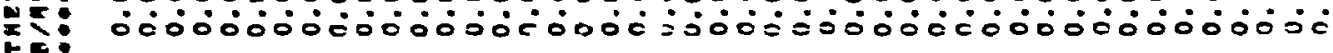

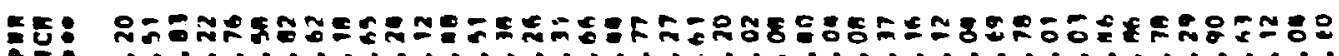

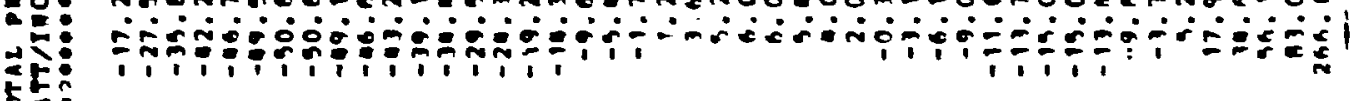

EE:

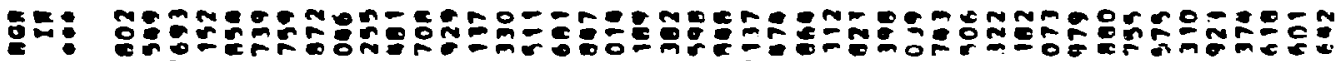
L:

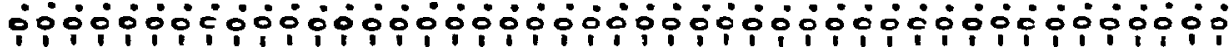

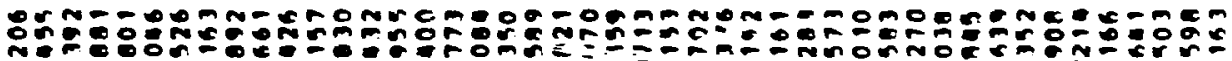

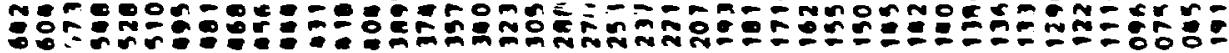

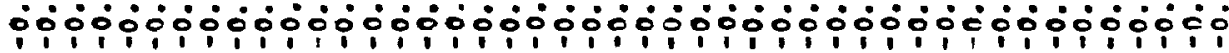

影:

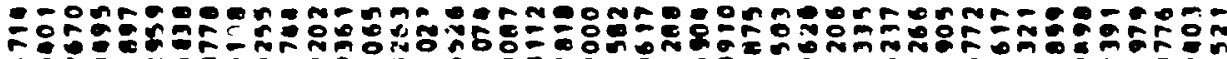
Ẽ

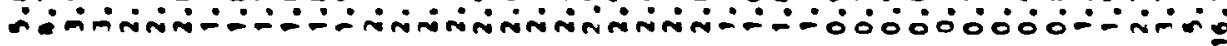

훙

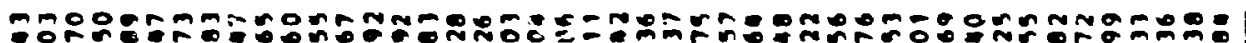

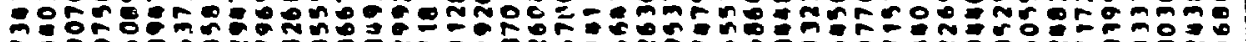

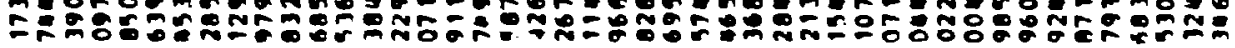
na:

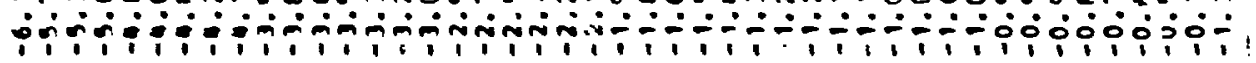

틀

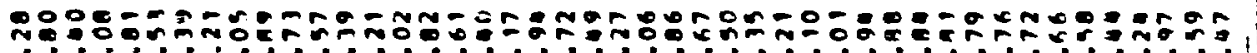

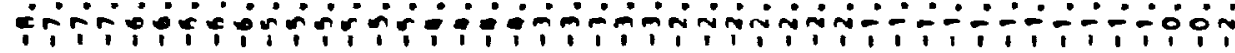

武:

aE:

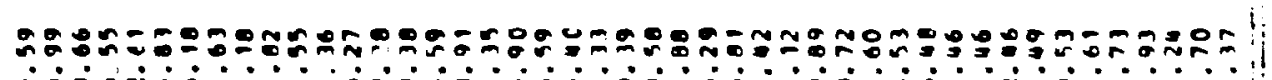

웅:

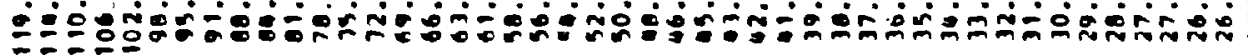

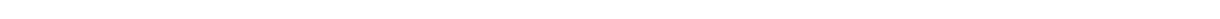

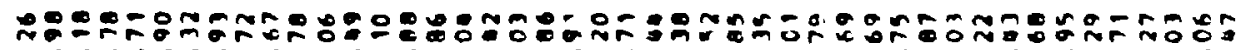

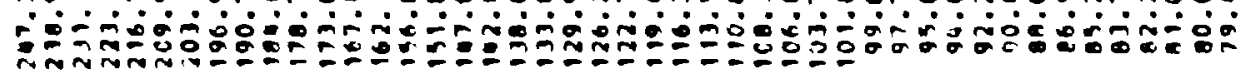

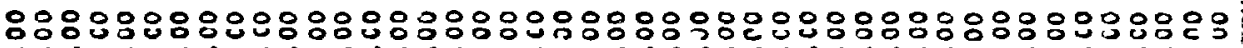

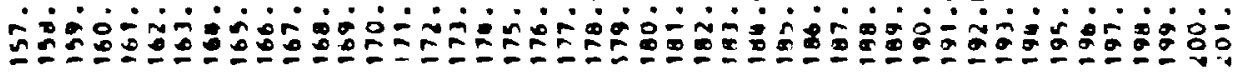




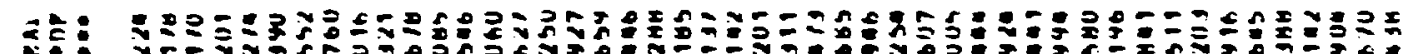

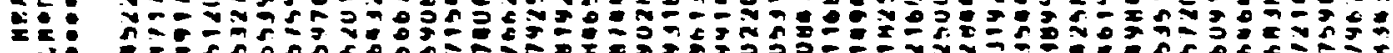

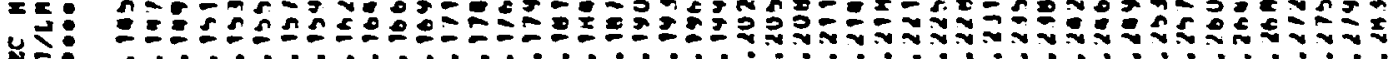

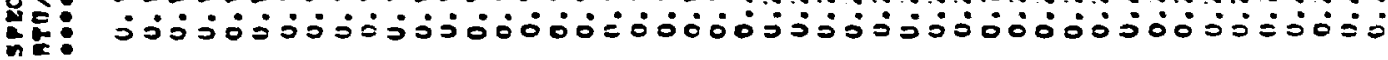

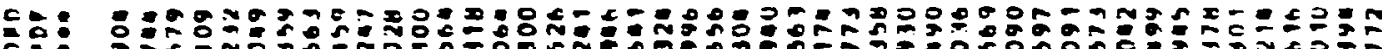

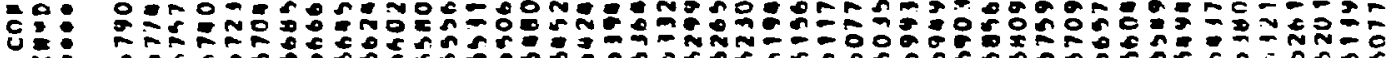

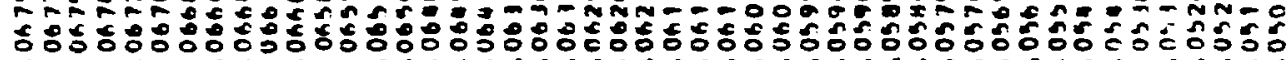

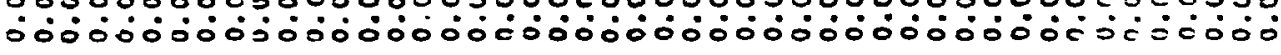

:

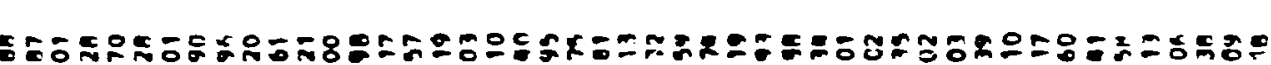

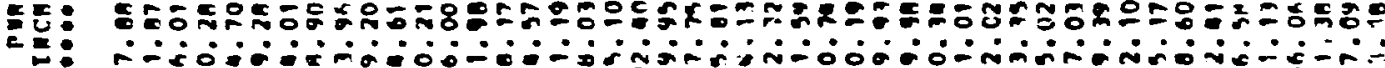

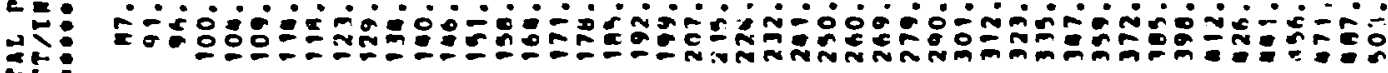

CE:

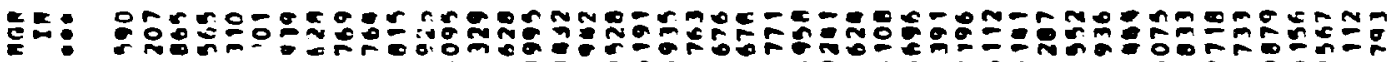

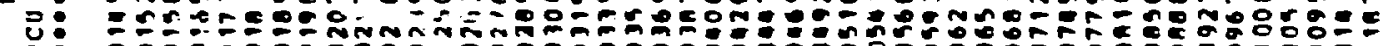

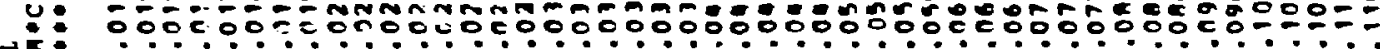

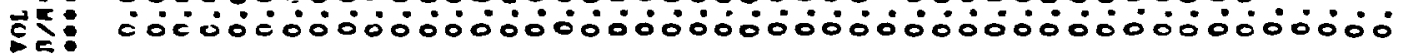

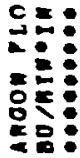

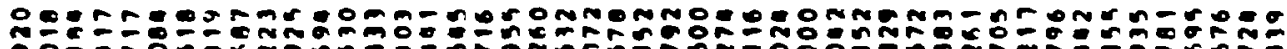

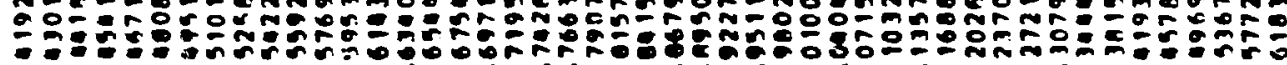

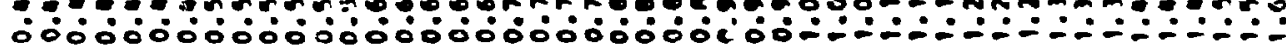

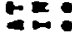

:-2:

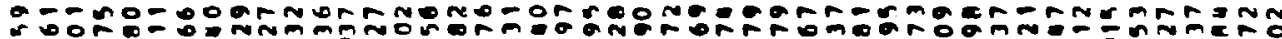

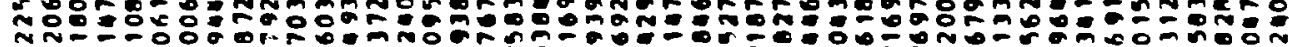

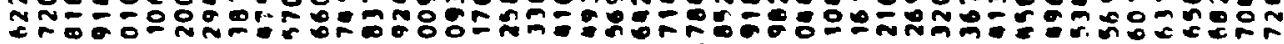

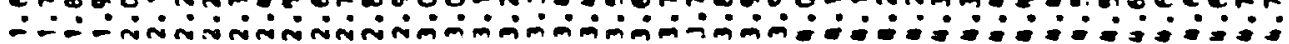

บ

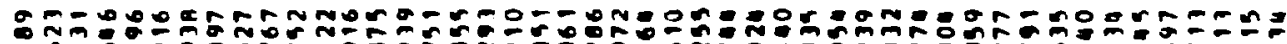

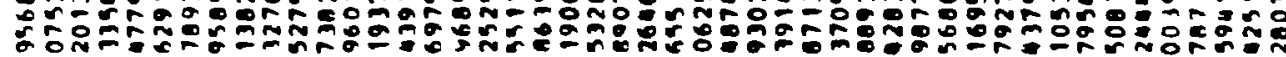
U.

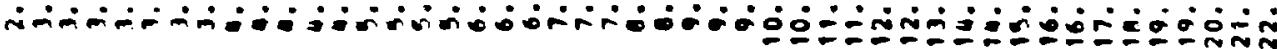

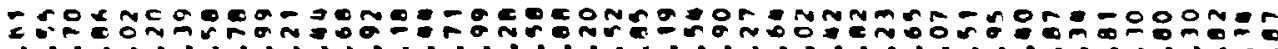

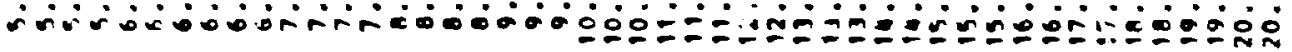

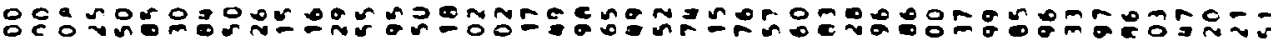

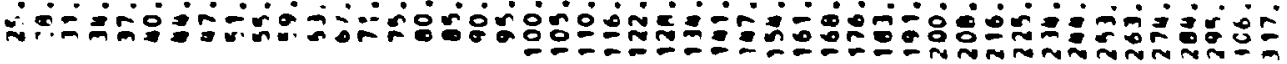

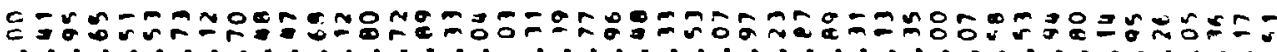


Table B. 2 (cont nued)

\begin{tabular}{|c|c|c|c|c|}
\hline 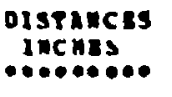 & 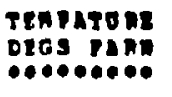 & 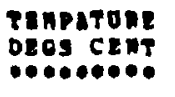 & 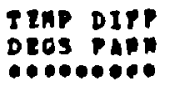 & 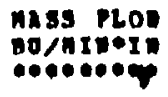 \\
\hline 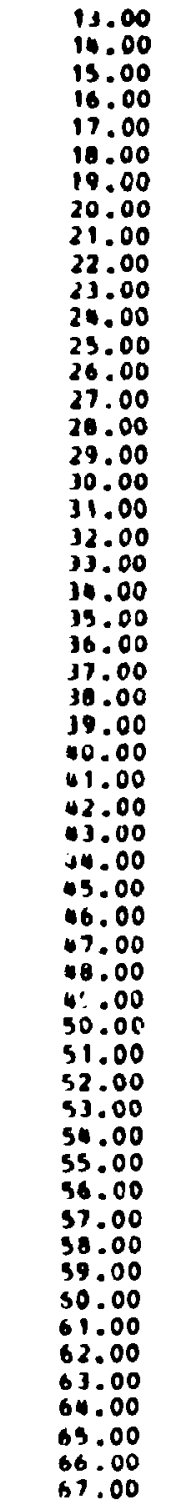 & 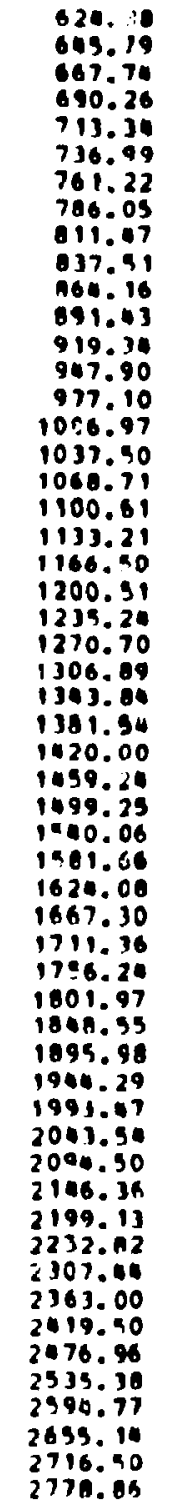 & 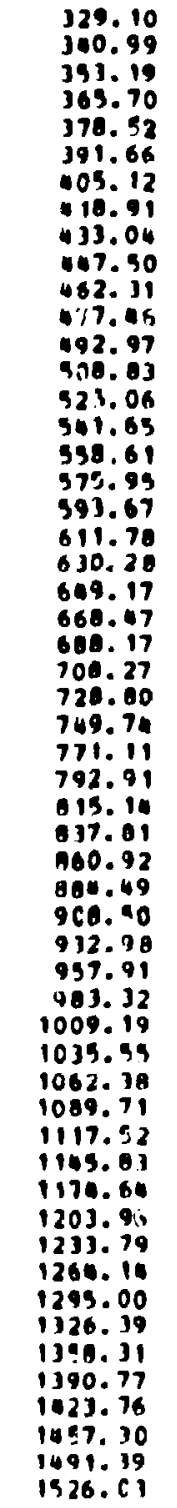 & 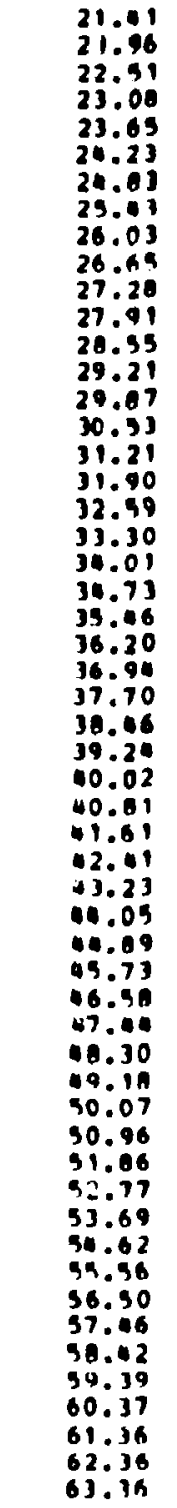 & 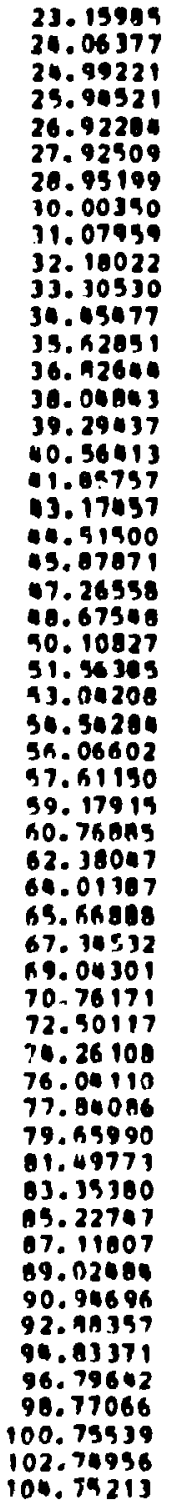 \\
\hline
\end{tabular}

COND AERT no/nIn?t?

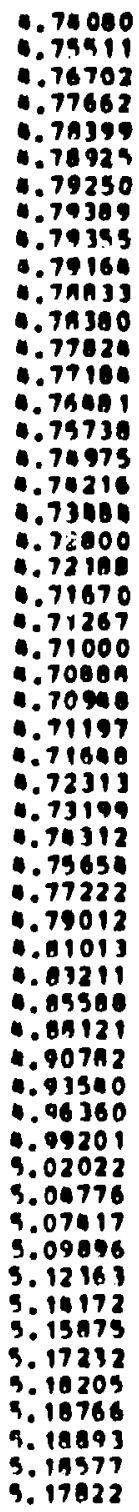

Aroon 120

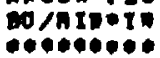

1.66029

1.70270

P.74586

.03020

1.87937

1.92421
1.97172

2.01990

2.06679

2.16147

2.21033
2.26497

2.31607

2. 36790

2.42049

2.52739

$2.6373 \AA$

2.69326

2.79967
2.80706

2.96197

2.92794
2.96279

3.00279

3.10329

3.16455

3.21907

3.35230

3.11620

3.90617

3.61212
3.67873

3.74602

3.91390

$3.9626 !$

9.021 nA

0.09252

$\because \because 16303$

$\because: 23509$

0.38179
0.4598

9.93000

0.60577
.60977

C.66177

$\because .7905$

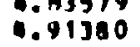

VOL neopene.

0.123609

0.120961

0.133651

0.1367

0.119706

0.153 w6

0.161160

0.167090

0.173133

0.145648

0.192110

$0.19 n 706$

0.205436

C.21970

0.226011

0.231693

0.201 UEs

0.256201

0.256042

0.271991

0.2794

$0.28 n 14$

0.296136

0.30000

0.313386

0.32204

0.339717

- 3 an 70

0.33791

0.367176
0.376560

0.30606 a

0.395684

0.00519

0.019258

0.425211

0.03527

0.459700

0.465063

0.076316

0.907043

0.497493

0.919180

0.530036

0.340919

0.551919

0.362940
0.3710009 rophl pon ontrywen

$\$ 19.60$

931.09

971.99

309.6

कก⿻. 19

627.07

666.14

604.2

706. 8

727.9

79.27

771.11

793.37

616.04

962. 70

คA6. 67

911. on

935.91

$961: 19$

1013. O4

1039.63

lons. Bts

1094.13

1190.39

1179.1"

$120 \mathrm{n} .91$

$124 n .0 n$

1299.72

1329.64

1369.05

1392. 05

1957.6.

1929.90

1937.60

1626.03

1650.59

1693.63

1730.82

1786.29

1837.73

1873.73

1904. 8n

1945.14

1912.90
2014.90
Pnen cons ancecenese

0.050102 0.04450 0.00 now 0.04622 0.007573 0.044274 0.004629 0.040479 0.000339 0.001065 0.002040 0.041829 0.00122 0.010528 0.000044 0.039400 0.034936 0.030 us $0.037 n 92$ 0.037000 0.036920 0.036477 0.036014 0.0.0.0.

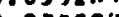
$0.03 n$ sh? 0.034235 $0.0334 h 6$ $0.03 j h 44$ 0.013054 0.013229 0.033021 0.032615 0.0 .32509 0.032154 0.032154 0.012040 0.031943 ר.031n 0.031710 0.031577 0.031437 0.031287 0.031124 0.030750 0.030535 0.030294 0.0 .30043 0.029468
SPEC nent nrodkent

0.207206 0.29u 0.24786 0.902219 0.90441 o. s04a is

0. Iloyes

0. seusta

O. $1201 \mathrm{an}$

o. $\$ 11112$

0.

0.9gnz24

0. Salney

o. sesogy

$0.131 \mathrm{~h} 10$

0.they 40

0.14 140?

0.161116

0. 1 thosts

$0.910 s 90$

0. J1ha in

D.jlygbe

n. 342215

0.945013

0.187164

0.49047

0. 1431 ish

0.944920

U. MOUHAY

0.40sion

u. ouvloz $0.010 n$ m 0.0121 ha .. Aisuos 0.011149 0.019 .124 0.01112 0.021400 10.025012 0.014111 0.0 Juyata 0.12264 10.00304 $0.43 y, 1$ 0.4 AHYOO 


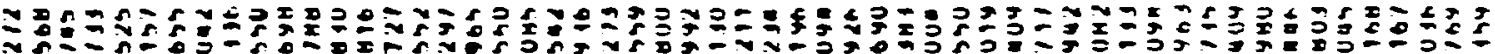

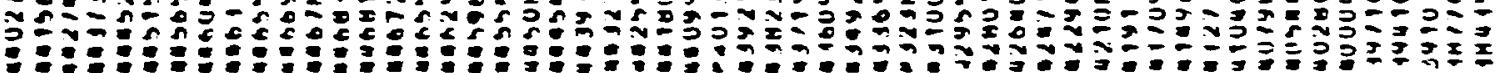

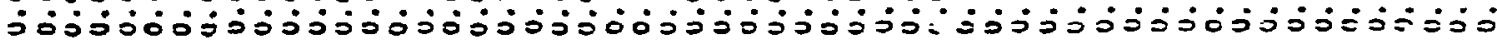

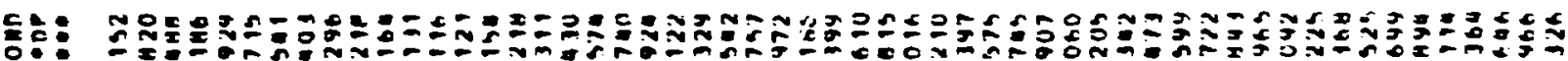

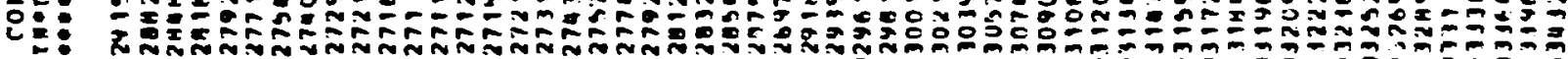

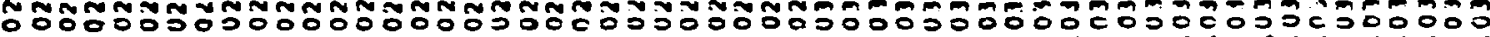

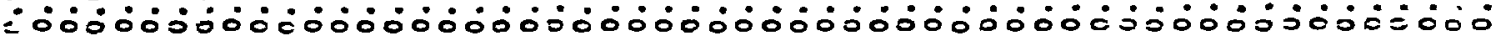

눈:

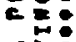

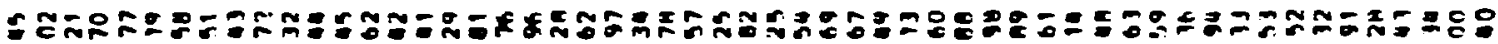

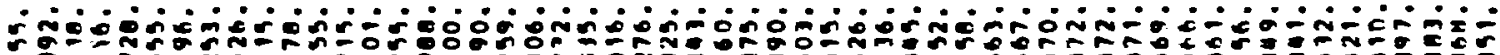

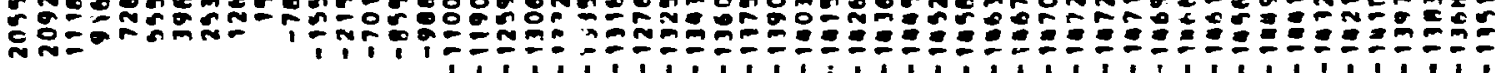

CE:

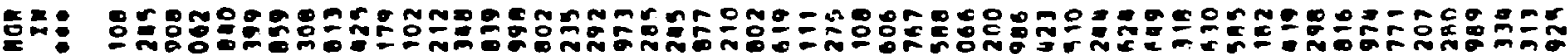
บ

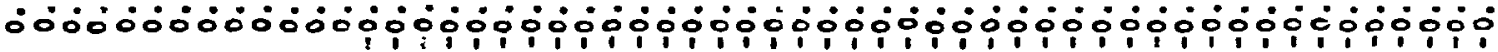

c:

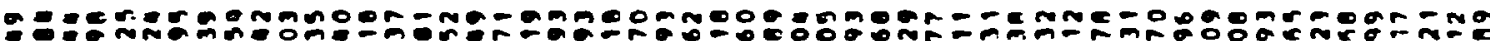

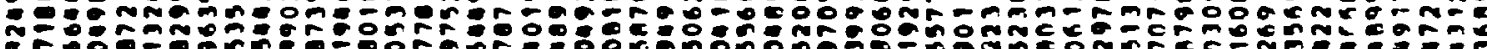

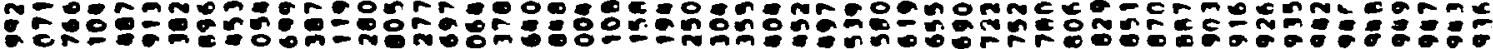

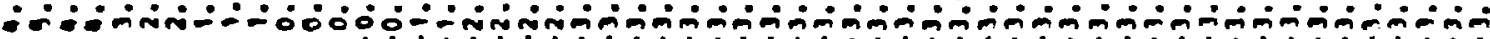

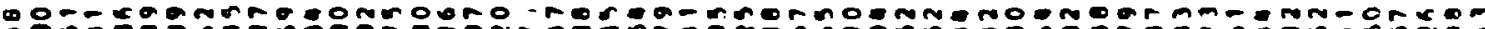

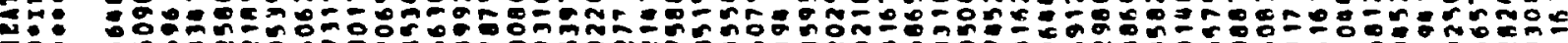

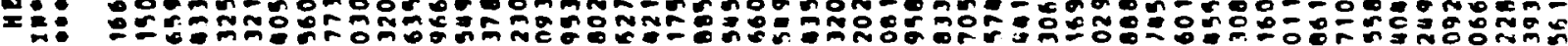

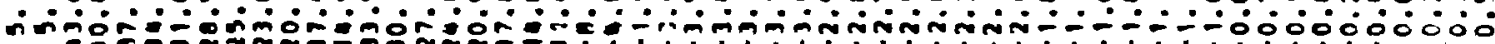

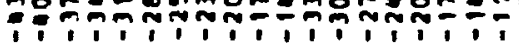

8:

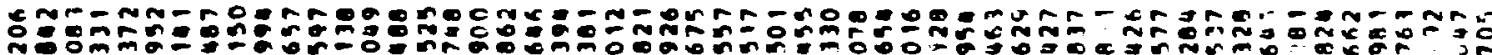

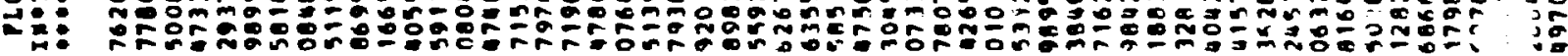
in:

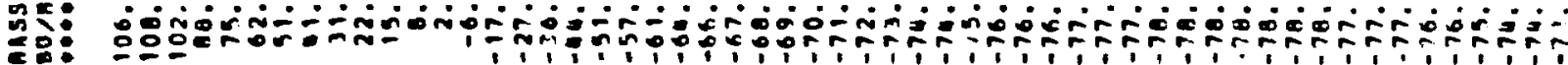

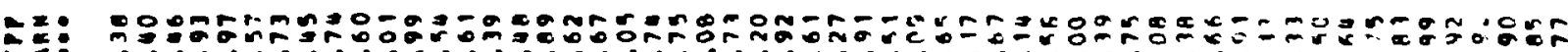
on - jóñ co: :

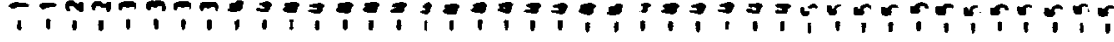

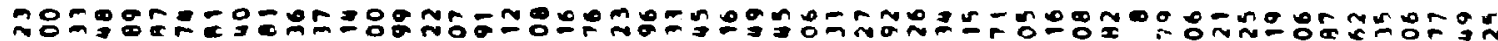

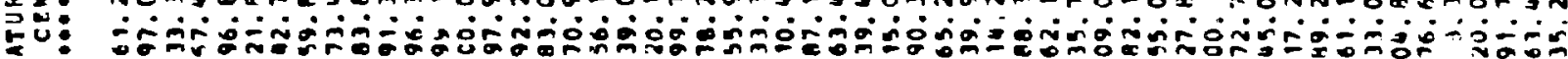
ज讨:

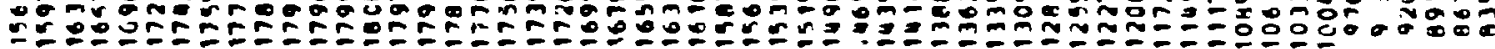

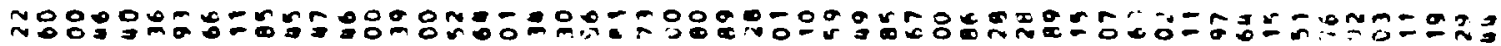

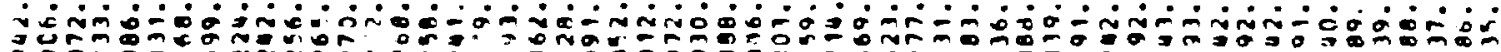

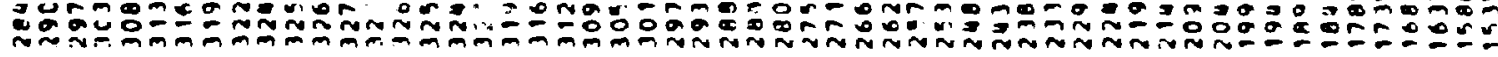

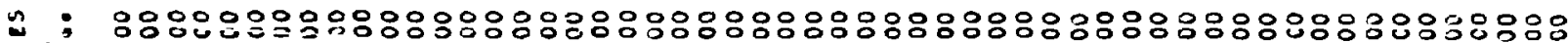

in:

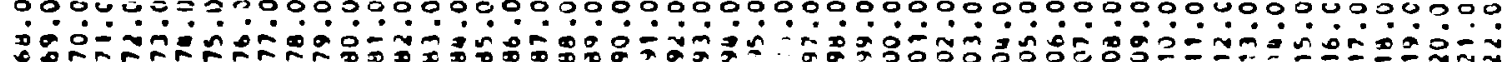




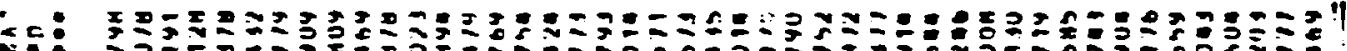

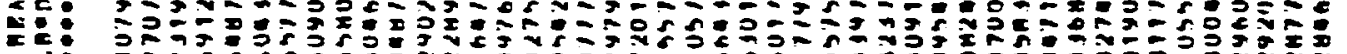

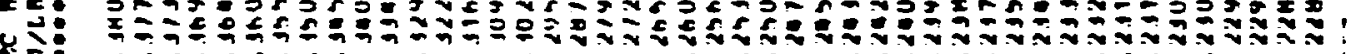

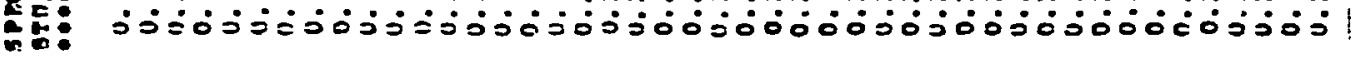

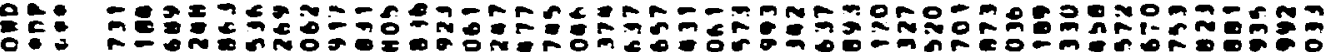

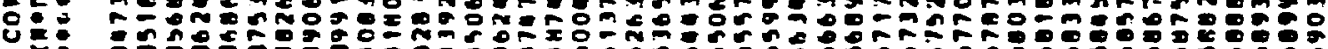

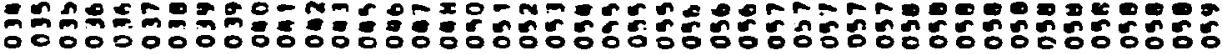

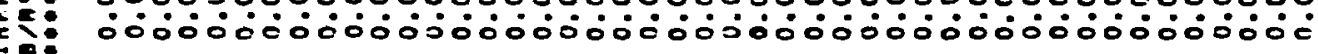

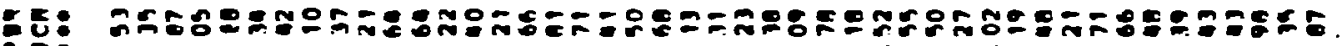

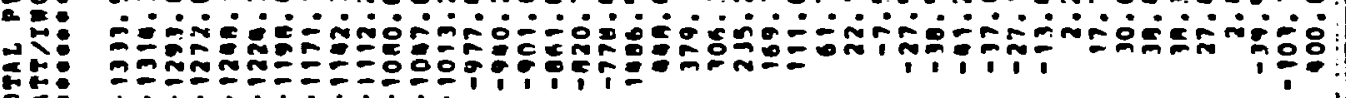
E:

흘

E⿱乛龰ำ

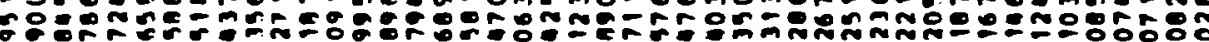

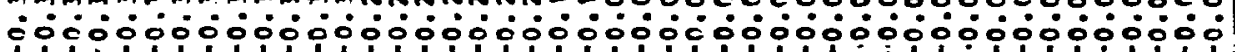

으:

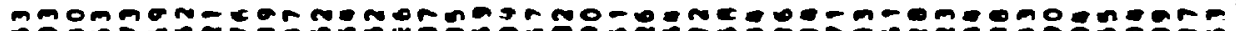

$2:$

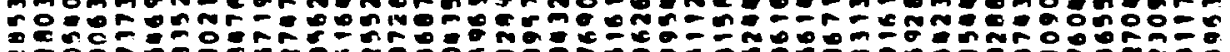

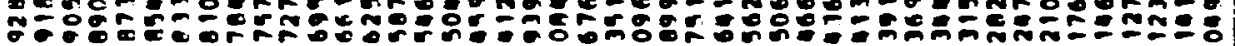

突:

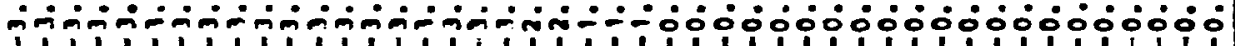

E:

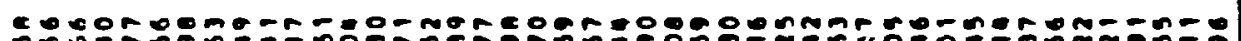

:

赵:

ç:

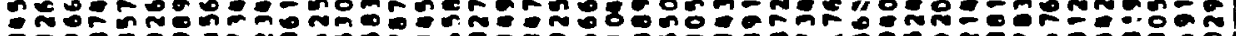

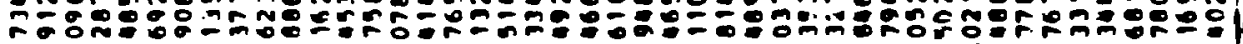

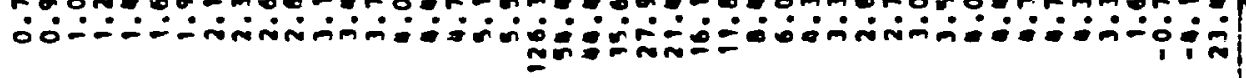

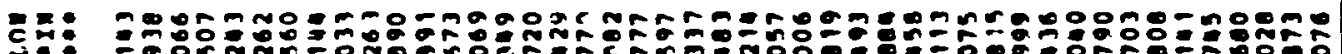
¿

S

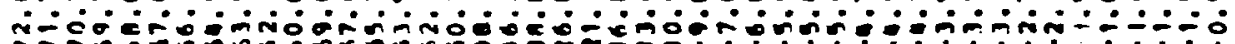

무:

$\therefore=$

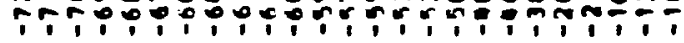

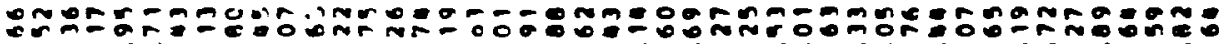

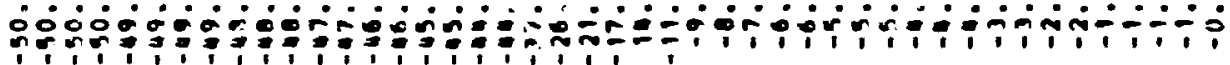

을 :

:

N:

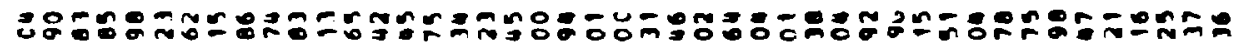

: \&̊ñ

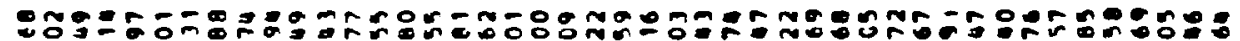

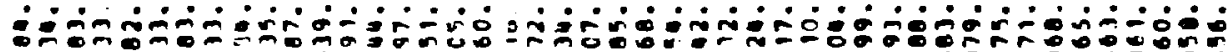

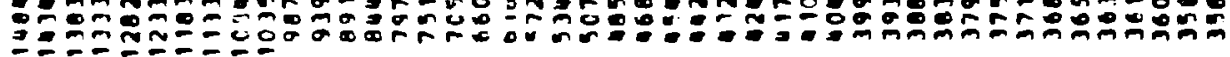

a)

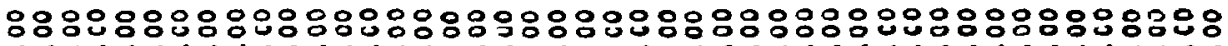

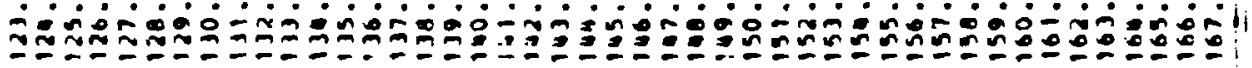


Appendix C

THERMAL CONDECTIVITY DATA AS A FUACTION OF TEYPERATURE FOR FUEL ELEMENTS FABRICATED FRJM TYPE H-32i AND TYPE प9-451 GRAPHITE

Table C.1. Therwal Conductivity and Specifj: H:at I Couposite Fuel Elements Made With Unireadiated H-327 Graplite as a Function of Temperature

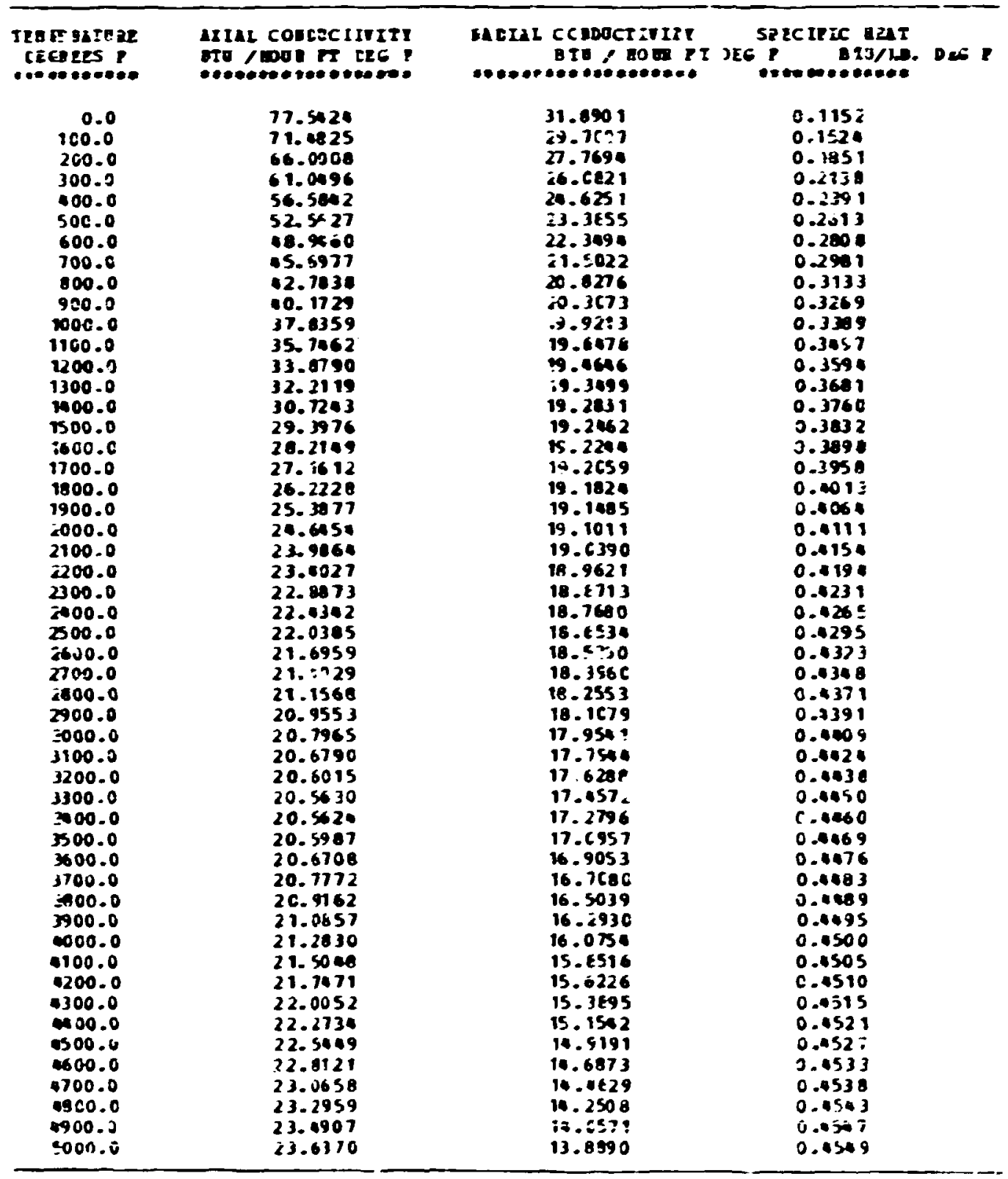


80

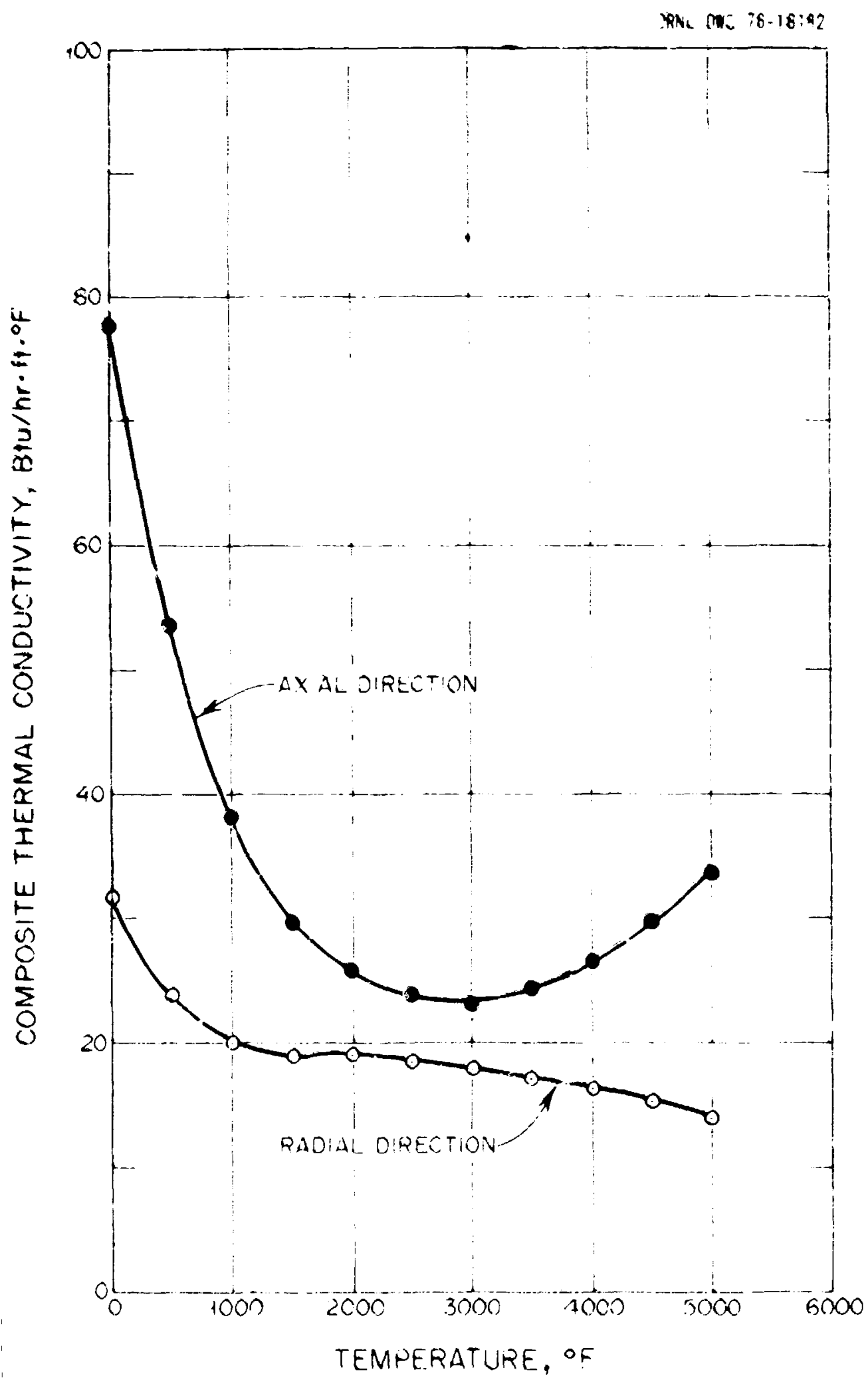

Fig. C.1. Axial and Radial Thermal Conductivities of Composite Fuel Elements Made with Unirradiated H-327 Graphite as a Function of Temperature. 
Tabie C.2. Thermal Conductivity and Specific Heat of Composite Fuel Eiements Made With Unirradiated H-451 Graphite as a Function of Temperature

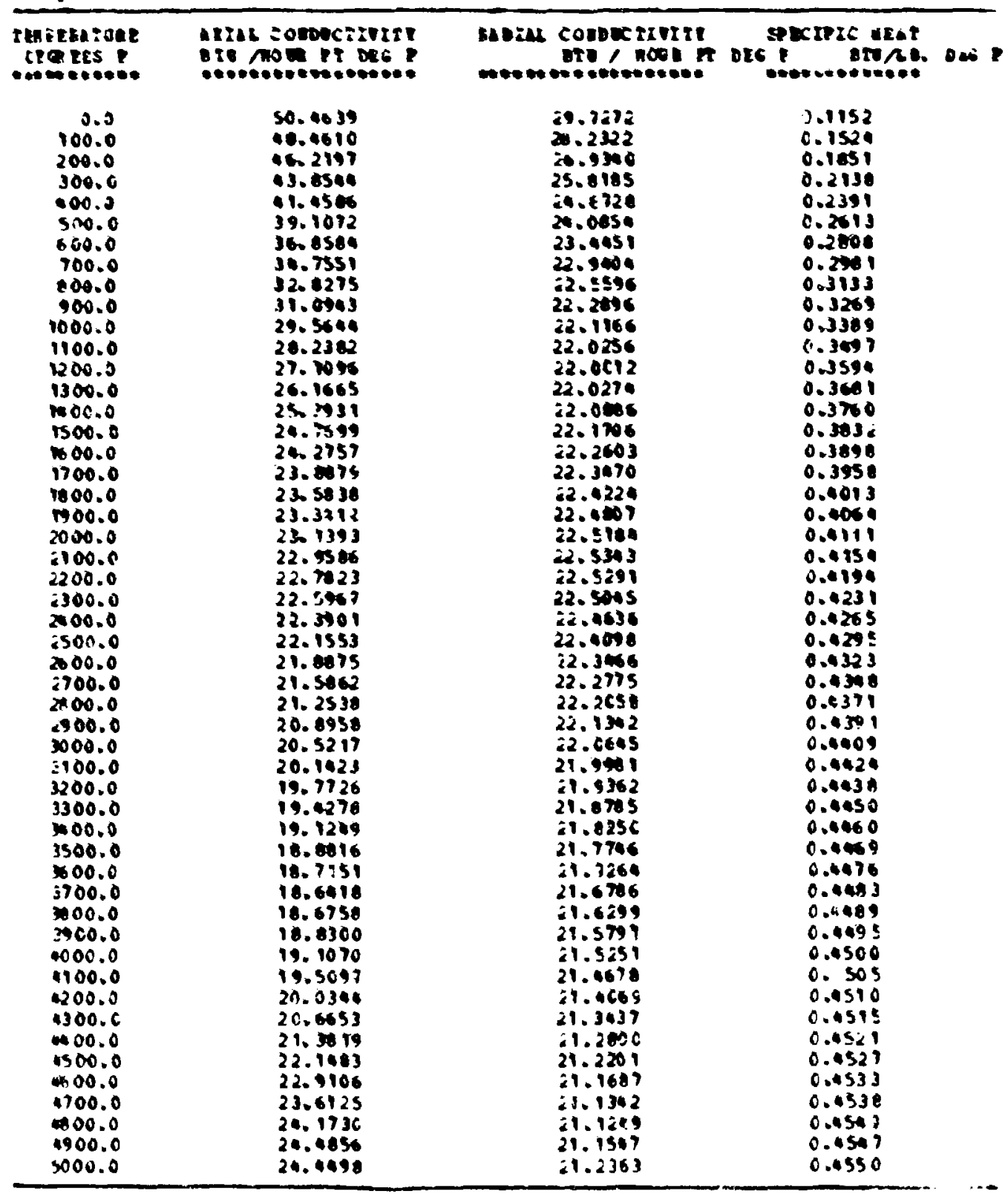


OMi ONG 76-18183

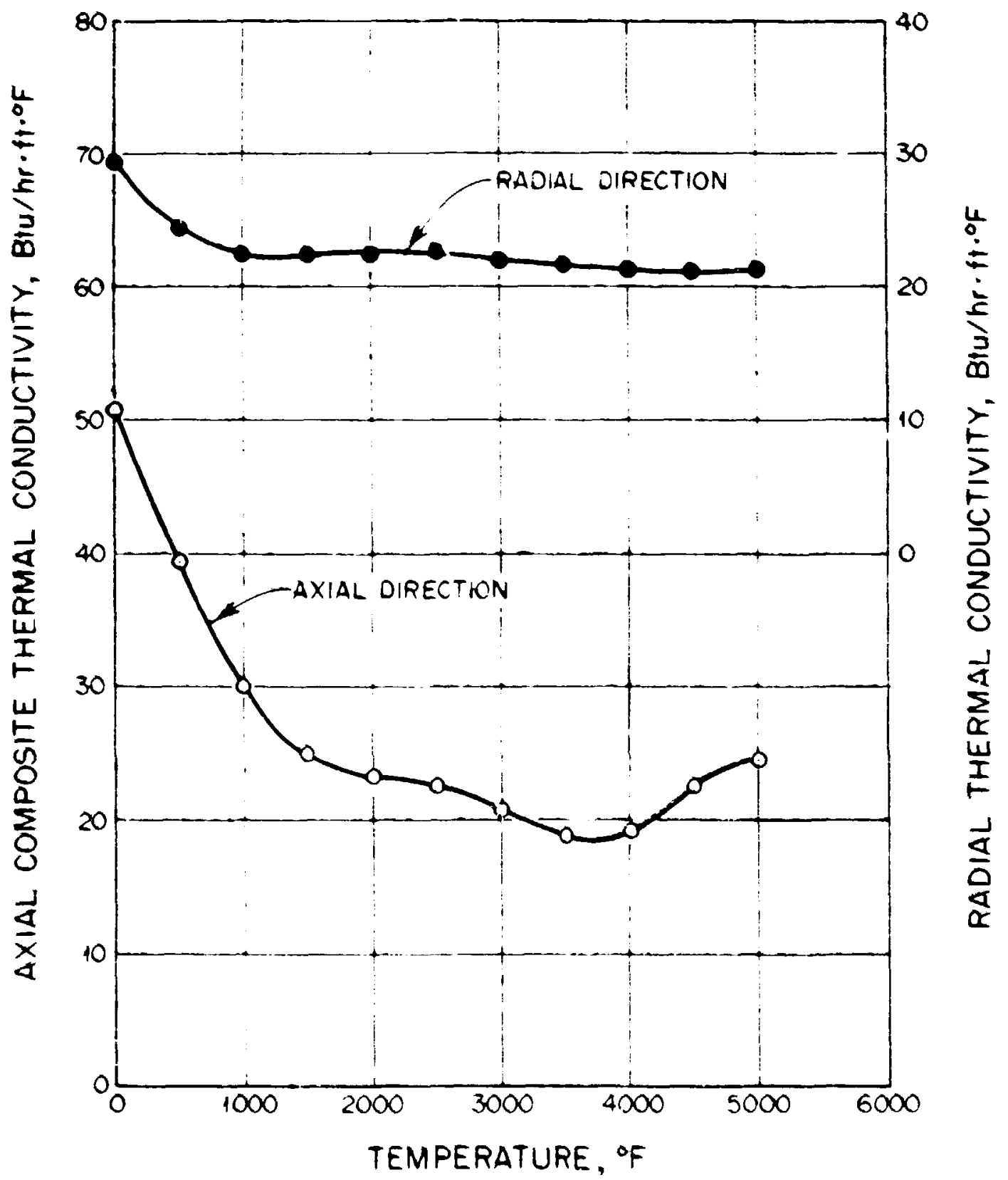

Fig. C.2. Axial and Radial Thermal Conductivities of Composite Fuel Elements Made With Unirradiated H-451 Graphite as a Function of To mperature. 
ORN/ENG/MAL -1

\section{Internal Dístribution}

1. P. Angelini
2. R. J. Beaver
3. H. Bender
4. R. J. Braatz
5. R. A. Bradley
6. A. J. Caputo
7. H. G. Cobb
8. H. E. Cochran
9. J. H. Coobs
10. B. F. Crup
11. F. C. Davis
12. R. G. Donnelly
13. B. C. Duggins
14. H. P. Eatherly
15. F. C. Fitrpatrick
16. H. R. Hamel
17. F. E. Harrington
18. L. C. Hensley
19. R. M. Hill
20. J. R. Horton
21. L. N. Howell
22. D. R. Johnson
23. P. R. Rasten
24. J. J. Rurtz
25. H. J. Lackey
26. G. M. Lawson

27. B. Lieberwan

28-29. G. W. Llem 11 yn

30. A. L. Lotts

31. J. E. Mack

32. S. R. Mcleany

33. R. J. Notz

34. A. R. Olsen

35. T. N. Pickel

36. A. S. Pruitt

37. D. P. Reid

38. J. E. Rushton

39. T. F. Scanlan

40. M. Simn-Tov

41. D. P. Stinton

42. R. R. Suchomel

43. V. J. Tennery

44. S. M. THeg

45. D. B. Trauger

46. J. E. Van Cleve

47. T. R. Weir

48. R. M. Young

49-50. Central Research Library

51. Document Reference Section

52-64. Laboratory Records Depertment

65. Laboratory Records, ORNL R.C.

66. ORNL Patent Office

\section{Externai Distribution}

67. J. G. Grundmann, Penn State University, Department of Hechanical Engimtering, 208 Mechanical Engineering Building, University Park, Pennsylvania 16802.

68-69. Director, ERBA, Division of Nuclear Fuel Cycle and Production, Washington, D.C. 20545.

70-71. Director, ERDA, Division of Reactor Development and Demonstration, Vashington, D.C. 20545.

72. Director, Reactor Division, ERDA, Oak Ridge Operations office, Post office Box E, Cak Ridge, Tennessee 37830 .

73. Research and Technical Support Division, ERDA, Oä Ridge Oparations Office, Post Office Box E, Oak Ridge, Tennessee 37830.

74-100. Technical Information Center, ERDA, Office of Information Services, Post office Box 62, Oak Ridge, Tennessee 37830. 